\title{
Family planning/reproductive health training manual: For private sector physicians
}

Evidence Project

Follow this and additional works at: https://knowledgecommons.popcouncil.org/departments_sbsr-rh How does access to this work benefit you? Let us know!

\section{Recommended Citation}

"Family planning/reproductive health training manual: For private sector physicians," PowerPoint slides. Cairo: The Evidence Project, 2018. 


\section{FAMILY PLANNING/REPRODUCTIVE HEALTH TRAINING MANUAL}

\section{FOR PRIVATE SECTOR PHYSICIANS}

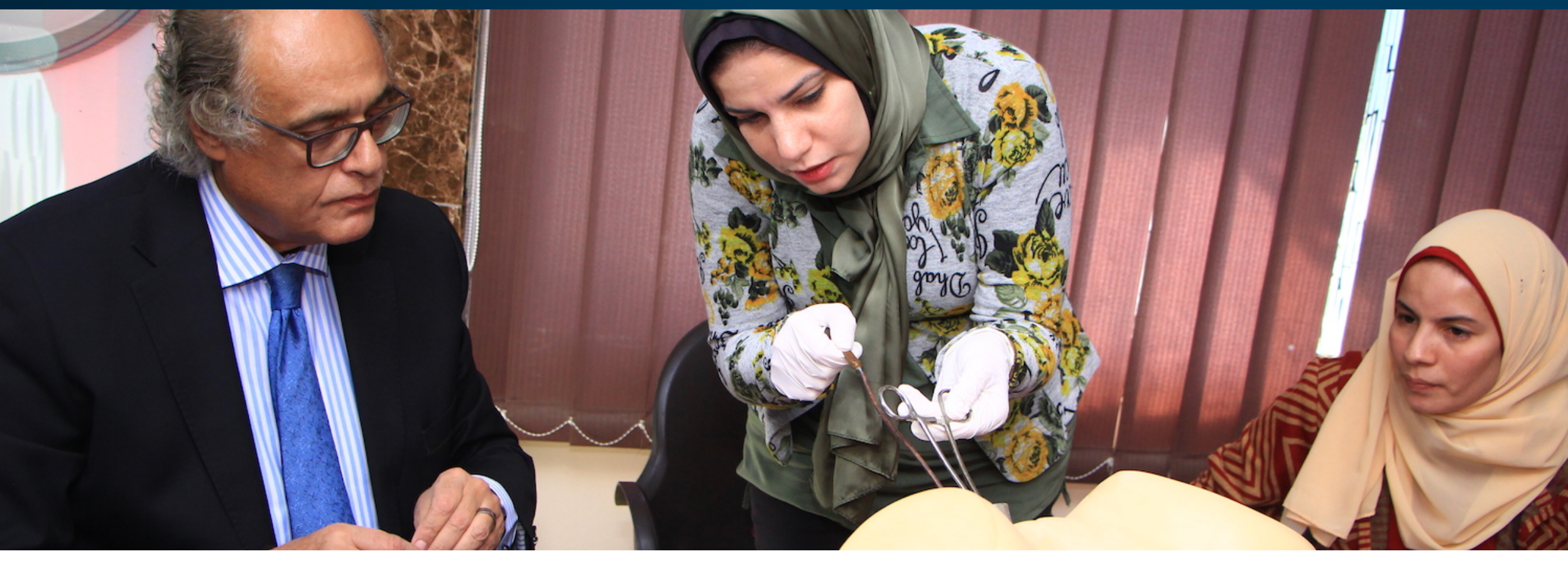




\section{DAY ONE}


SESSION 1 


\section{Introduction}

- Goal

- Learning Objectives

- Schedule

- Expectations and ground rules.

- Pre-test 


\section{Goal}

- Ensure availability and Improving the quality of $\mathrm{FP} / \mathrm{RH}$ services delivered by private sector providers for youth in Egypt. 


\section{Objectives}

- By the end of this training course, each participant will be able to:

- Discuss the population problem in Egypt highlighting latest findings of EDHS (2014) and importance of family planning as a human right.

- Discuss available contraceptives with respect to mode of action, effectiveness, indications, WHO medical eligibility criteria, how to use and side effects,

- Manage problems associated with contraceptive practice. 


\section{Objectives (cont.)}

- Enable clients to safely and effectively use specific FP methods through proper counseling and service provision.

- Demonstrate the steps of client clinical assessment.

- Demonstrate appropriate CuT380A IUD insertion and removal on pelvic model.

- Follow infection control practices in FP clinics.

- Describe postpartum and post abortion FP methods. 


\section{Objectives (cont.)}

- Demonstrate appropriate implanon insertion and removal on arm model.

- Discuss Emergency contraception pills (ECPs) with clients.

- Identify the role of men in FP and GBV.

- Discuss issues surrounding FGM/C.

- Identify sexually transmitted infections (STIS) in $\mathrm{RH}$ practices. 
SESSION 2 


\section{Objectives}

- By the end of the session the participant will be able to:

- Discuss the elements of the population problem in Egypt and it's consequences.

- Discuss FP practice in Egypt using DHS 2014 data.

- Explore Health benefits of family planning as a human rights.

- Explain healthy timing and spacing of pregnancies. 
تعريف المشكلة السكانية : هي الخلل في التوازن بين موارد الدولة المبات

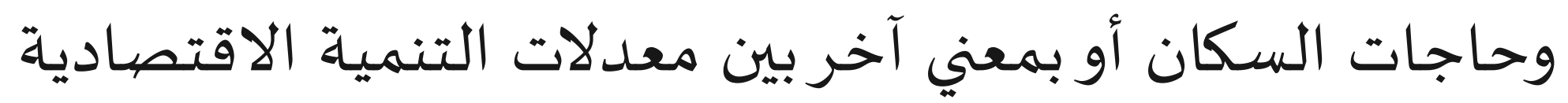



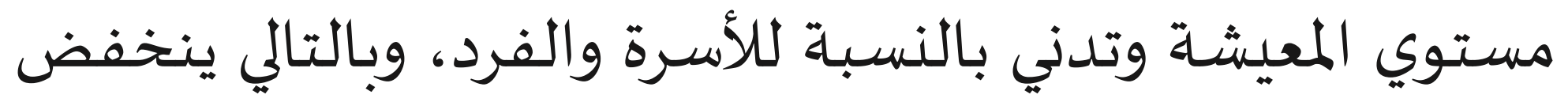

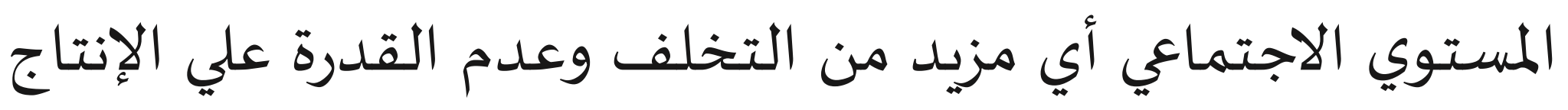
نتيجة تدني خصائص السكان فتتفاقم المشكلة. 


\section{الآثار السلبية الناتجة عن المشكلة السكانية}

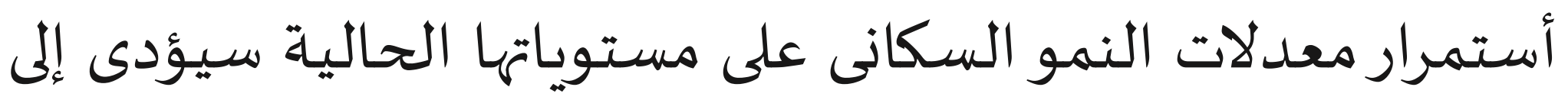



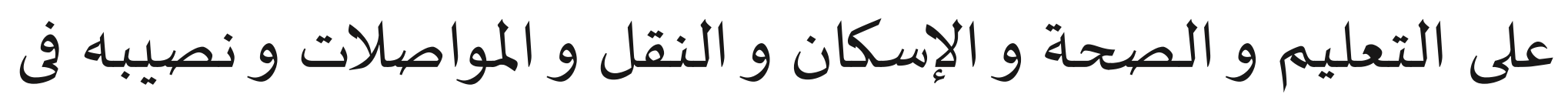

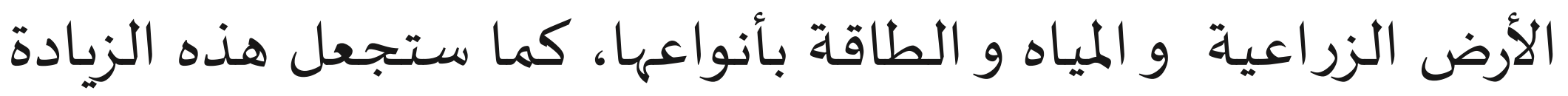
الحد من البطالة و الأمية والإكتفاء الغذائى أكثر صعوبة المانة.

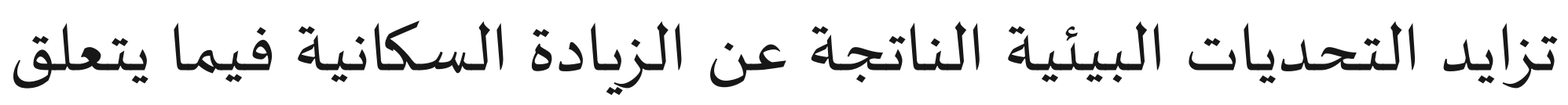


النفايات مما ينعكس سلبا على صحة المواطنين. 
الارتقاء بنوعية المواطن المصرى من خلال خفض معدلات الزياده

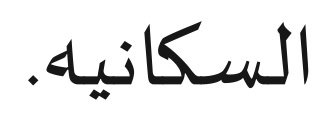

$$
\begin{aligned}
& \text { أعادة التوزيع الجغرافي والسكاني لمصر. } \\
& \text { الارتقاء بالخصائص السكانية. }
\end{aligned}
$$

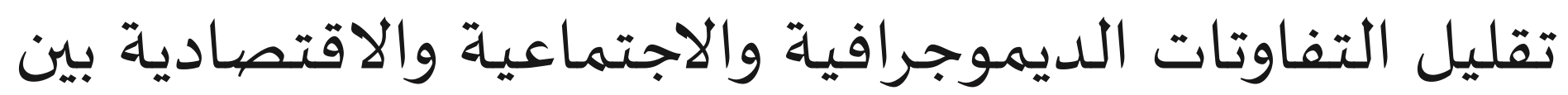
المجموعات السكانية والمناطق الجغرافية المختلفة. 


\section{Population Situation in Egypt}

- Total population was 88 million at the time of EDHS in 2014.

- The latest figure according to CAPMAS is 93.2 million in Jun 2017.

- More than one third of Egypt's population is under the age of 15 years.

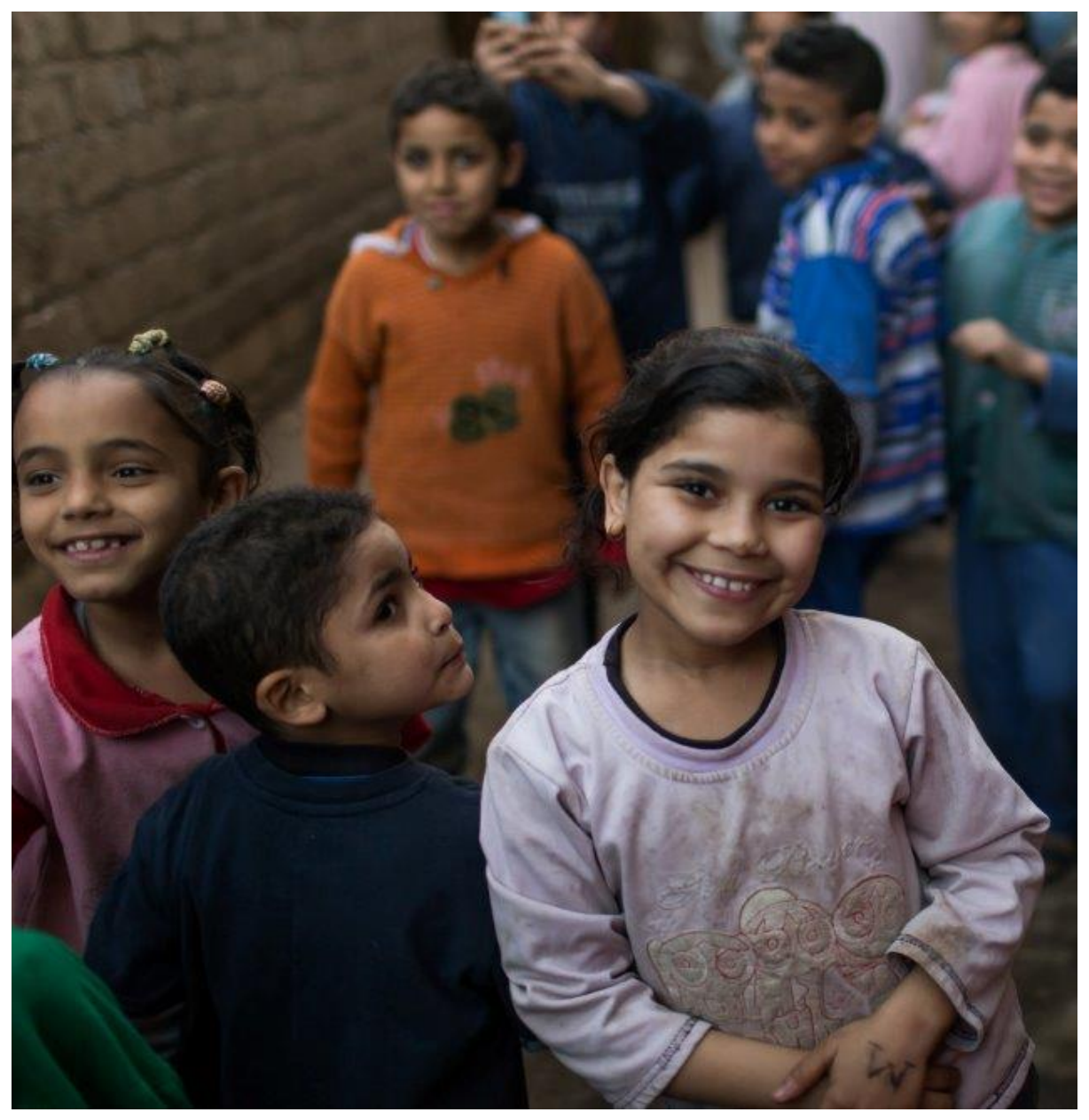




\section{Fertility in Egypt}

- Total fertility rate is defined as: the number of children a woman would have by the end of her childbearing (or reproductive) years.

- Total fertility rate has increased from 3 in 2008-EDHS to 3.5 in 2014-EDHS. 


\section{Fertility Trends}

\section{8-2014}

Births per woman for a three-year period before the survey

5






\section{Fertility by Place of Residence}

Births per woman for a three-year period before the survey

4.5

4

3.5

3

2.5

2

1.5

1

0.5

0

Urban Governorates
3.4

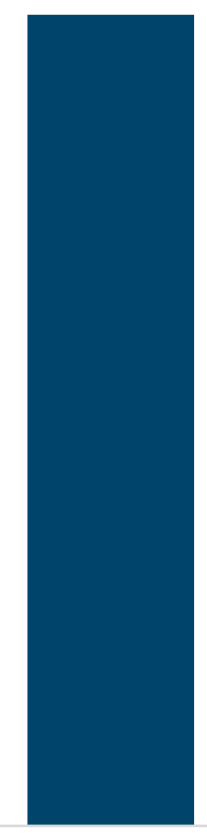

Lower Egypt
3.8



Upper Egypt
3.9

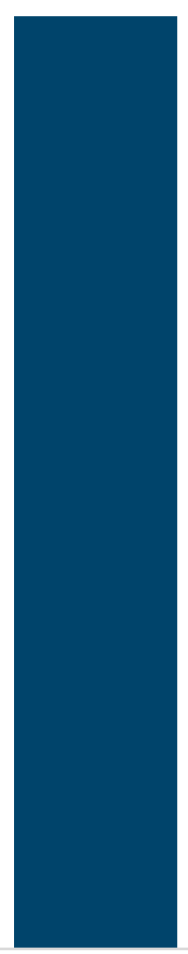

Frontier Gove morates* 


\section{Fertility by Place of Residence}

- Governorates with the lowest fertility rates:

- Alexandria: 2.2

- Cairo: 2.6

- Governorates with the highest fertility rates:

- Matrouh: 4.8

- Fayoum: 4.6

- Souhag: 4.3

- Assuit: 4.2 


\section{Median Age at First Birth for Women}

- Although the legal age at marriage for women in Egypt is 18 years, $6.4 \%$ of women age 15-17 were ever-married while $6.2 \%$ were currently married.

- Teenage Childbearing: $7 \%$ of married women between the ages of 15-19 are already mothers and $4 \%$ are pregnant with their first child. 


\section{Current Use of Contraception}

Percentage of currently married women aged 15-49

70

60

59

57

50

40

30

20

10

0
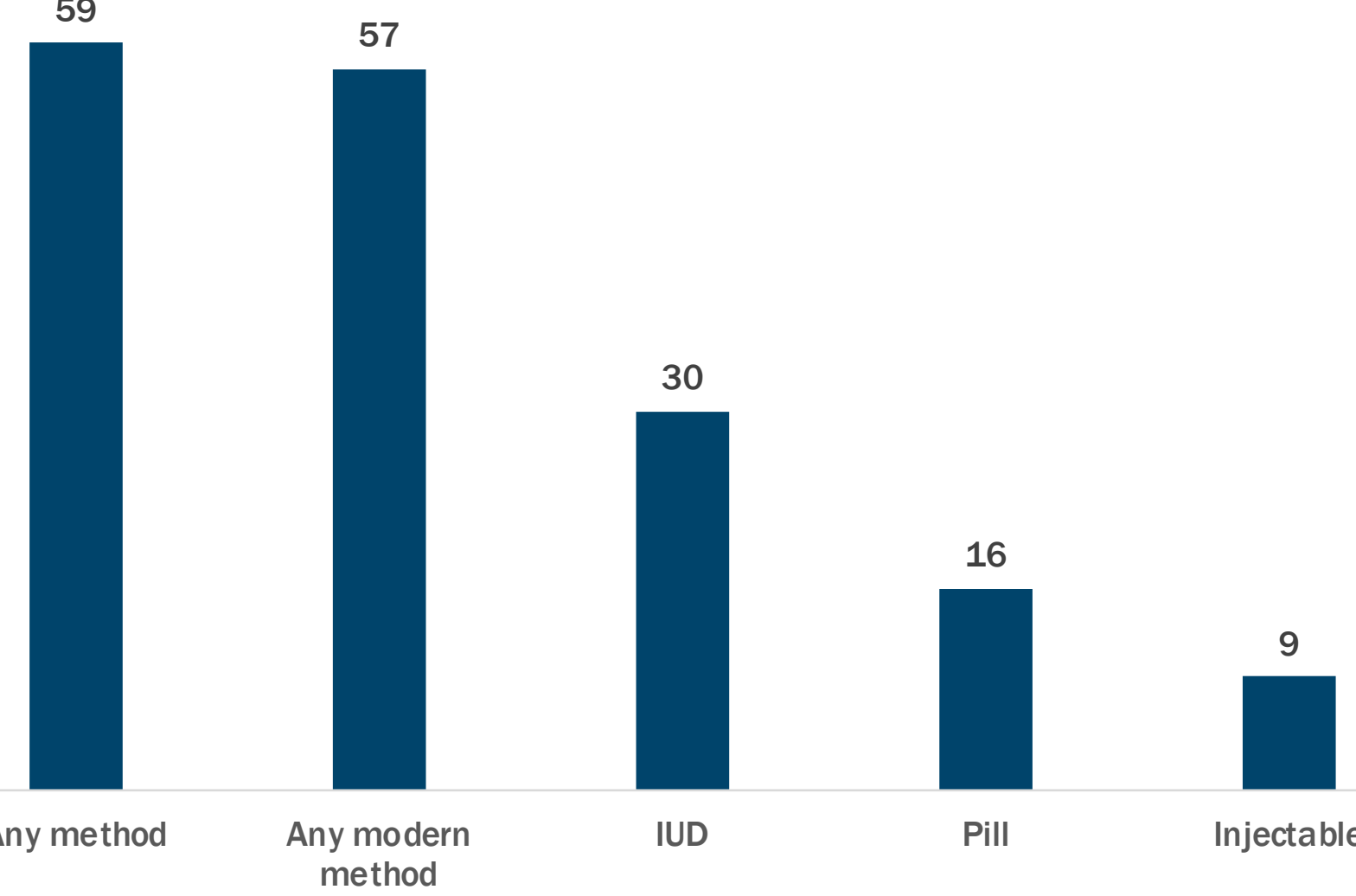

3

Pill

Injectable

Other Modern Method 


\section{Trends in Use of Family Planning}

Percent of currently married women aged 15-49

70

60

56

50

40

38

30

20

10

0
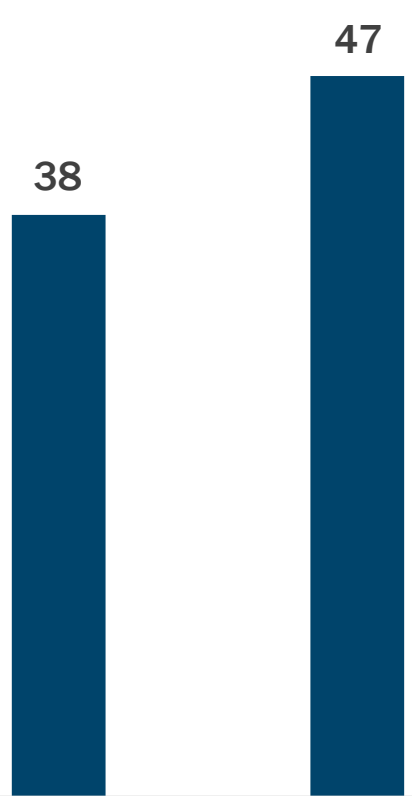

48

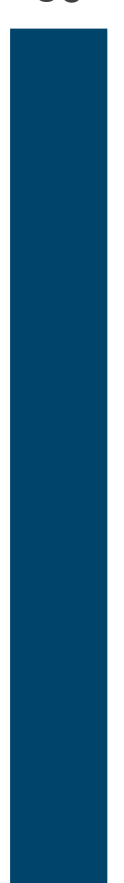

59

60

59 


\section{Governorates with Contraceptive Use at/Below the National Average}

Percent of currently married women aged 15-49 using any method of contraception

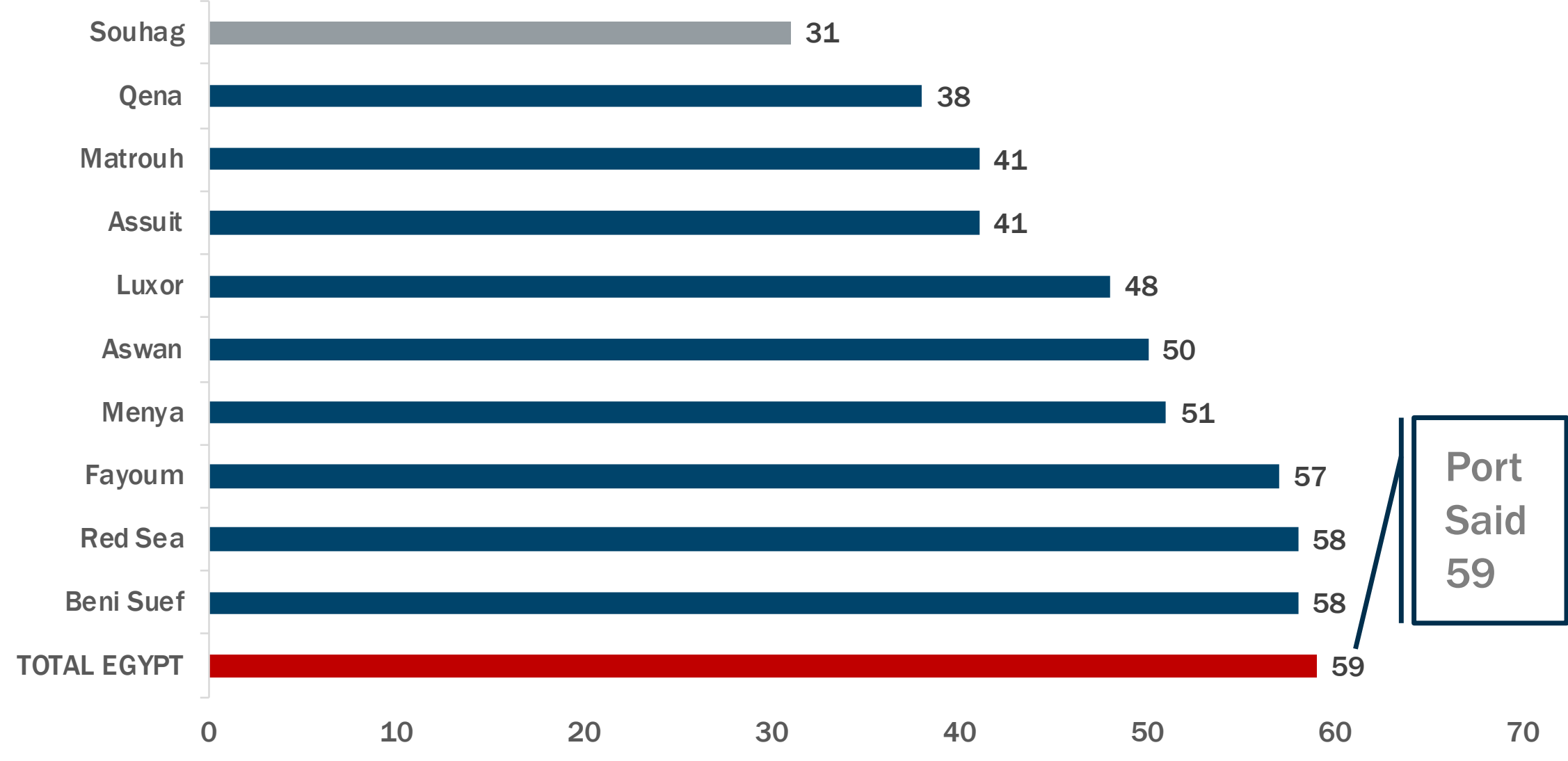




\section{Source of Contraception}

Percent distribution of current contraceptive users

90

80

70

60

50

40

30

20

20

10

0
57

43

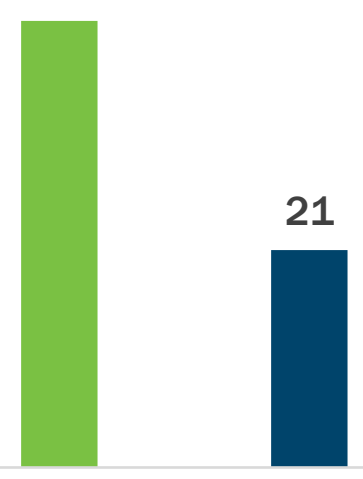

Total

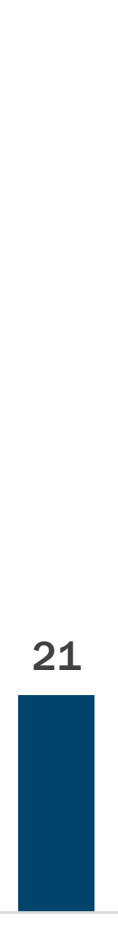

Female Sterilization
83

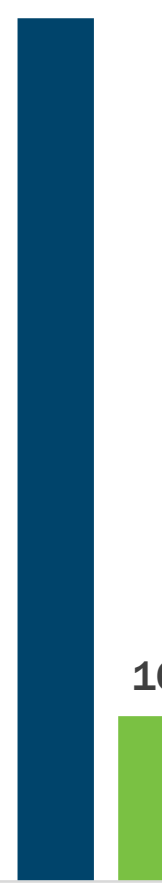

Injectable

Condom

Injectable

16

63



IUD

Pill

- Public Sector $\quad$ Private Sector 


\section{Unmet Need for FP services}

- Women are considered as having an unmet need for family planning if they wish to: space their next birth OR to limit childbearing altogether BUT are not using contraception.

- $13 \%$ of currently married women have an unmet need for family planning (5\% spacing $8 \%$ limiting)

- In other words: 2 million women in Egypt don't get the FP methods they need to space or stop child bearing. 


\section{Women's Reasons for Not Using FP}

- Fertility- related reasons (Breastfeeding, not menstruated since last birth).

- Opposition to use (woman opposed, husband opposed, religious prohibition).

- Lack of knowledge.

- Method- related reasons (Fear of side effects, costs to much, preferred method not available, lack of access/ too far, no method available............) 


\section{Contraception Discontinuation Rates by Reason for Stopping}

35

30

25

20

15

10

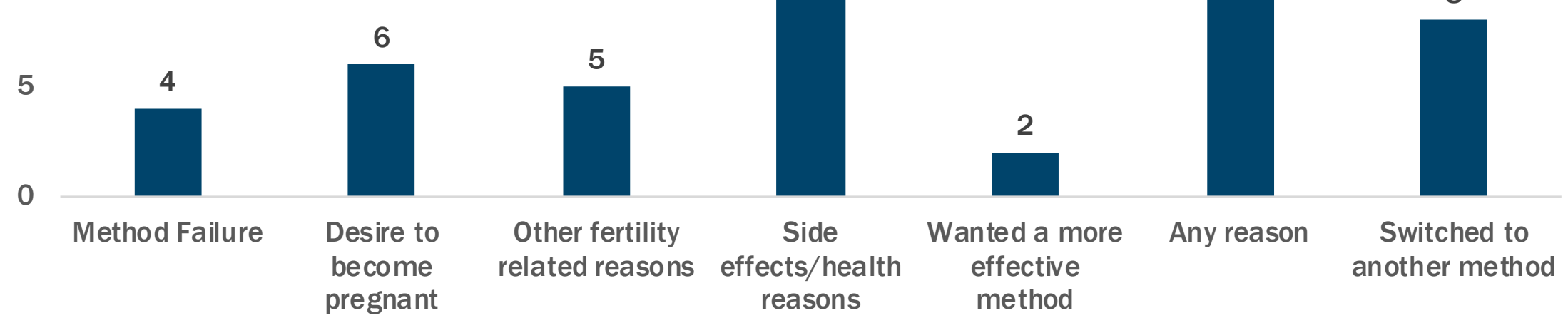




\section{Contraceptive Discontinuation Rates by Method and Reason for Stopping Use}

Among women age 15-49

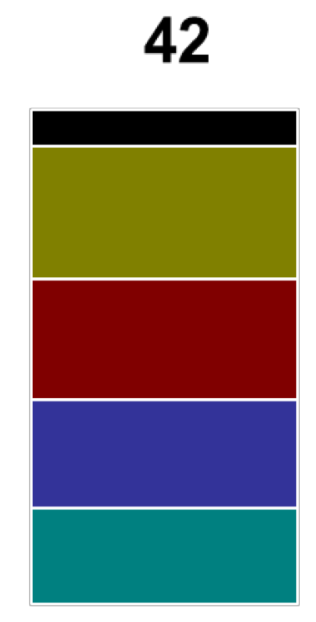

Pill

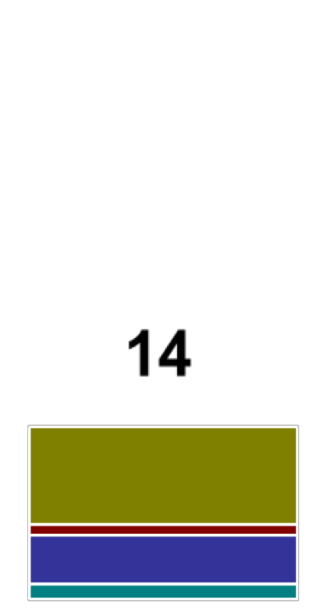

IUD

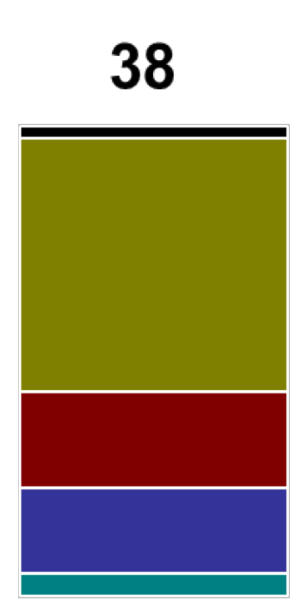

Injectables
- Method failure

n Other fertility related reasons

- Wanted more effective method
- Desire to become pregnant

- Side effects/health reasons 


\section{Family Planning as a Human Right in Egypt}

- Free Decision and Access to FP is a fundamental human right.

- It was proclaimed by the International Community since the late 1960s.

- That is the right to decide Whether, When and How many times to have children, as well as the means to exercise this human right. 


\section{Informed Decision-making /Voluntarism}

- Includes effective access to information to FP choices, to the counselling services and supplies needed.

- Freedom of choice to obtain or decline services.

- No pressures or element of force, fraud, deceit, or misrepresentation affects the decision. 


\section{Clients' Rights}

- Information: The right to learn about the benefits and availability of family planning.

- Access: The right to obtain services regardless of sex, creed, color, marital status or location.

- Choice: The right to decide freely whether to practice family planning and which method to use.

- Safety: The right to be able to practice safe and effective family planning.

- Privacy: The right to have a private environment during counseling or services. 


\section{Clients' Rights}

- Confidentiality: The right to be assured that personal information will remain confidential.

- Dignity: The right to be treated with courtesy, consideration, and attentiveness.

- Comfort: The right to feel comfortable when receiving services.

- Continuity: The right to receive contraceptive services and supplies for as long as needed.

- Opinion: The right to express views on the services offered. 


\section{Healthy Timing and Spacing of Pregnancies}

- Healthy timing and spacing of pregnancies helps women bear children at healthy times in their lives.

- Mothers and infants are more likely to survive and stay healthy when spacing between pregnancies by 3-5 years. 


\section{Healthy Times for a Pregnancy}

- Educate families on FP role in ensuring pregnancies occur at the healthiest times in a woman's life:

- Between ages 20 and 35.

- At least 24 months after a live birth* - this interval is consistent with the WHO/UNICEF recommendation of breastfeeding for 2 years.

- At least 6 months after a miscarriage. 


\section{Healthy Timing and Spacing of Pregnancies}

Method Mix

- Expand the mix of available contraceptives, including long-acting, reversible methods, to help couples effectively delay, time, space, and limit pregnancies to achieve their fertility intentions. 


\section{Benefits of Family Planning}

- Save the lives of countless women and children

- Reduces infant and child mortality.

- FP reduces the risk of unintended pregnancy among women living with HIV with subsequent reduction in mother to child transmission few infected babies.

- FP reduces adolescent pregnancy and its subsequent complications. 


\section{Benefits of Family Planning (cont.)}

- Help alleviate poverty

- Reduces stress on the environment and economy,

- Ensure families are better able to feed, clothes, and educate their children.

- FP practice decrease maternal mortality (MM) by $30 \%$.

- Reduces unsafe abortion and its consequences.

- Female and male condoms help in preventing STIs and HIV transmission (dual protection). 


\section{Benefits of Family Planning (cont.)}

- Help in treating or reducing the following conditions:

- Acne

- Cyclic breast pain

- Dysmenorrhea

- Ectopic pregnancy

- Functional ovarian cysts

- Endometriosis

- Hirsutism associated with PCOS

- Iron deficiency anemia

- Metrorrhagia- Mid-cycle

- Ovulatory pain

- Ovarian and endometrial cancer

- Premenstrual syndrome

- Uterine fibroids. 


\section{SESSION 3}




\section{Objectives}

- By the end of the session the participant will be able to:

- Describe the anatomy of female and male reproductive system.

- Explain the physiology of female reproductive system.

- Demonstrate the steps of client clinical assessment. 


\section{External Female Genitals}

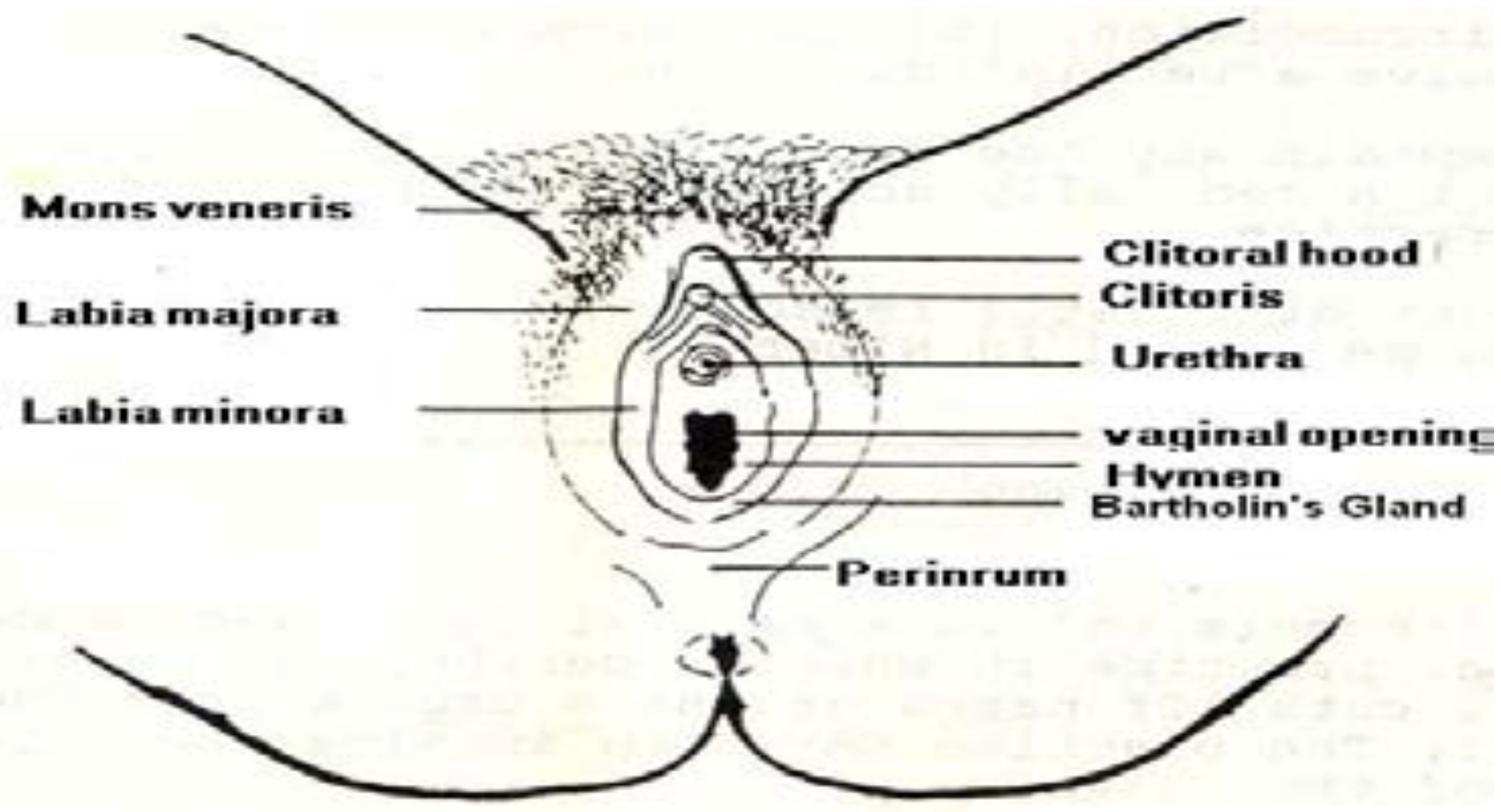




\section{External Female Genitals}

- Mons pubis: is a pad of fatty tissue over the pubic bone, which becomes covered with hair during puberty, protects the internal sexual and reproductive organs.

- Labia majora: Two spongy folds of skin - one on either side of the vaginal opening covering and protecting the genital structures.

- Labia minora: Two erectile folds of skin between the labia majora that extend from the clitoris on both sides of the urethral and vaginal openings. 


\section{External Female Genitals (cont.)}

- Clitoris: An erectile, hooded organ at the upper joining of the labia that contains a high concentration of nerve endings and is very sensitive to stimulation.

- Clitoris, labia minora, labia majora and mons pubis along with the opening of the vagina, are known as the vulva. 


\section{External Female Genitals (cont.)}

- Urethra: The external opening of the urinary tract.

- Vaginal opening: The external opening of the genital tract.

- Hymen: A thin membrane that surrounds the opening to a young woman's vagina.

- Perineum: is a network of muscles located between and surrounding the vagina and the anus that support the pelvic cavity and help keep pelvic organs in place. 


\section{Role of External Female Genitals}

- Enabling sperms to enter the body.

- Protecting the internal genital organs from infectious organisms.

- Directs the urine in a stream by the labia minora preventing splashing and soiling of the vulva.

- Providing the sexual pleasure (Clitoris and Labia are very rich in nerve endings that make them extremely sensitive organs. Touch stimulation of the nerve endings in the labia and especially the clitoris produces sensations of sexual pleasure and orgasm) 


\section{Internal Female Genitals}

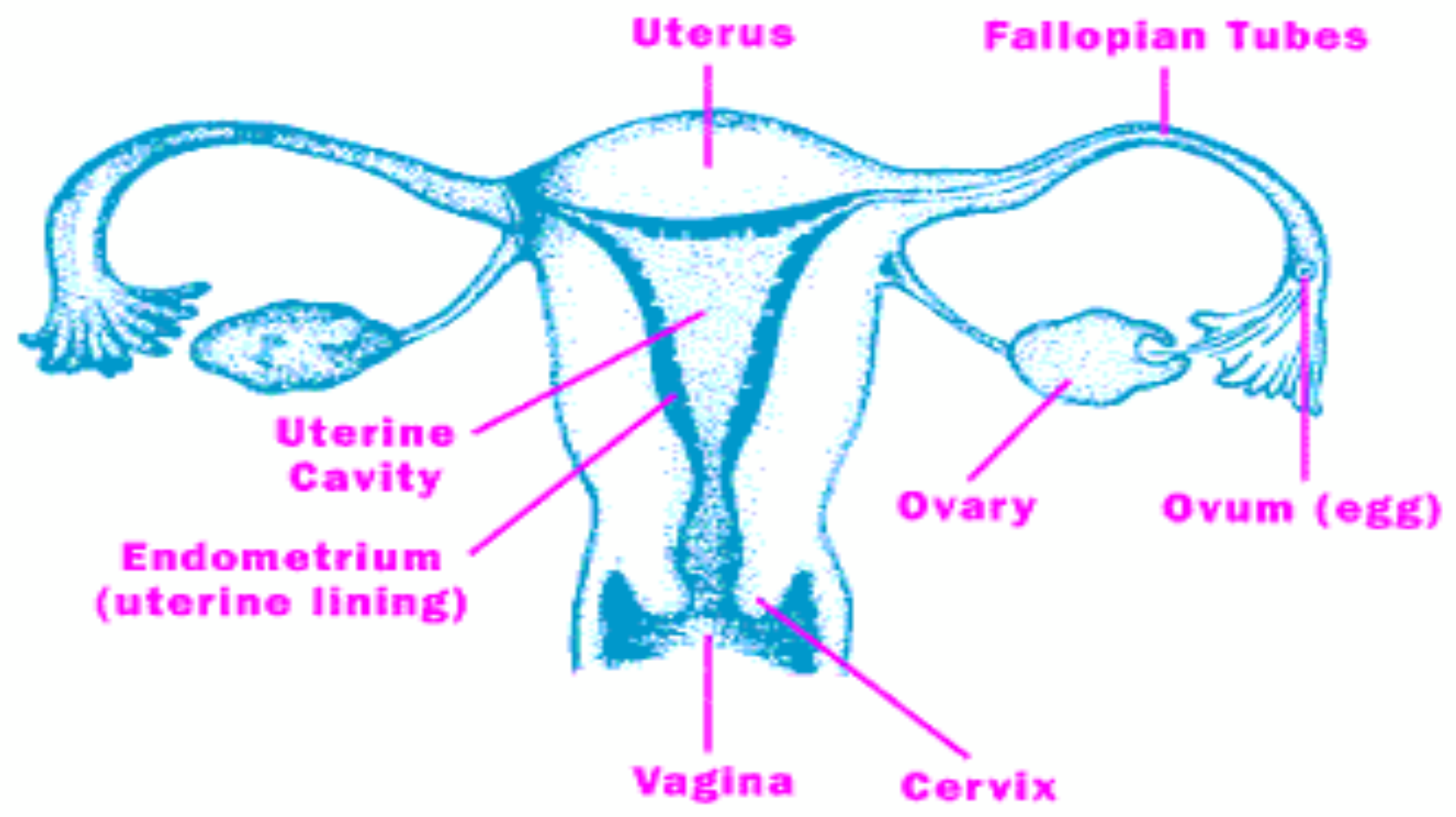




\section{Internal Female Genitals}

- Vagina: is a muscular, highly expandable, tubular cavity leading from the vestibule to the uterus.

- Bartholin's glands: two small, round structures. These glands secrete a mucus-like fluid during sexual arousal, providing vaginal lubrication.

- Cervix: the lower part of the uterus that protrudes into the vaginal canal, it has an orifice that allows passage for menstrual flow from the uterus and passage of sperm into the uterus. 


\section{Internal Female Genitals}

- Ovaries: are two organs located at the end of each fallopian tube, that produce ova (releasing one per month from puberty to menopause).

- Uterus: is a hollow, thick-walled, pearshaped, muscular organ located between the bladder and rectum, it is the site of implantation of the fertilized ovum. 


\section{Internal Female Genitals}

- Endometrium: lining of the uterus, which gradually thickens and then is shed during monthly bleeding.

- Fallopian tubes: are a pair of tubes that extend from the upper uterus, extending out toward the ovaries (but not touching them), through which ova travel from the ovaries toward the uterus and in which fertilization of the ovum takes place. 


\section{Physiology of Female Reproductive System}

Endocrine Regulation of Ovarian Functions

Oestrogen/ progesterone negative feedback

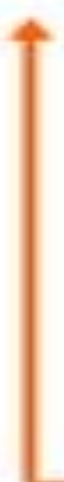

Information from higher centres in the brain

Hypothalamus

GnRH

-Pituitary

LH

$\mathrm{FSH}$

- Ovary 


\section{Physiology of Reproduction}

- Menstruation is a woman's monthly bleeding.

- The menstrual blood is partly blood and partly endometrium shedding.

- Most menstrual periods last from three to five days.

- Menstrual Cycle:

- A cycle starts on the first day of a period (the 1st bleeding day).

- The average menstrual cycle is 28 days long.

- The parts of the body involved in the menstrual cycle include the brain, pituitary gland, uterus and cervix, ovaries, fallopian tubes, and vagina. 


\section{Physiology of Female Reproductive System}

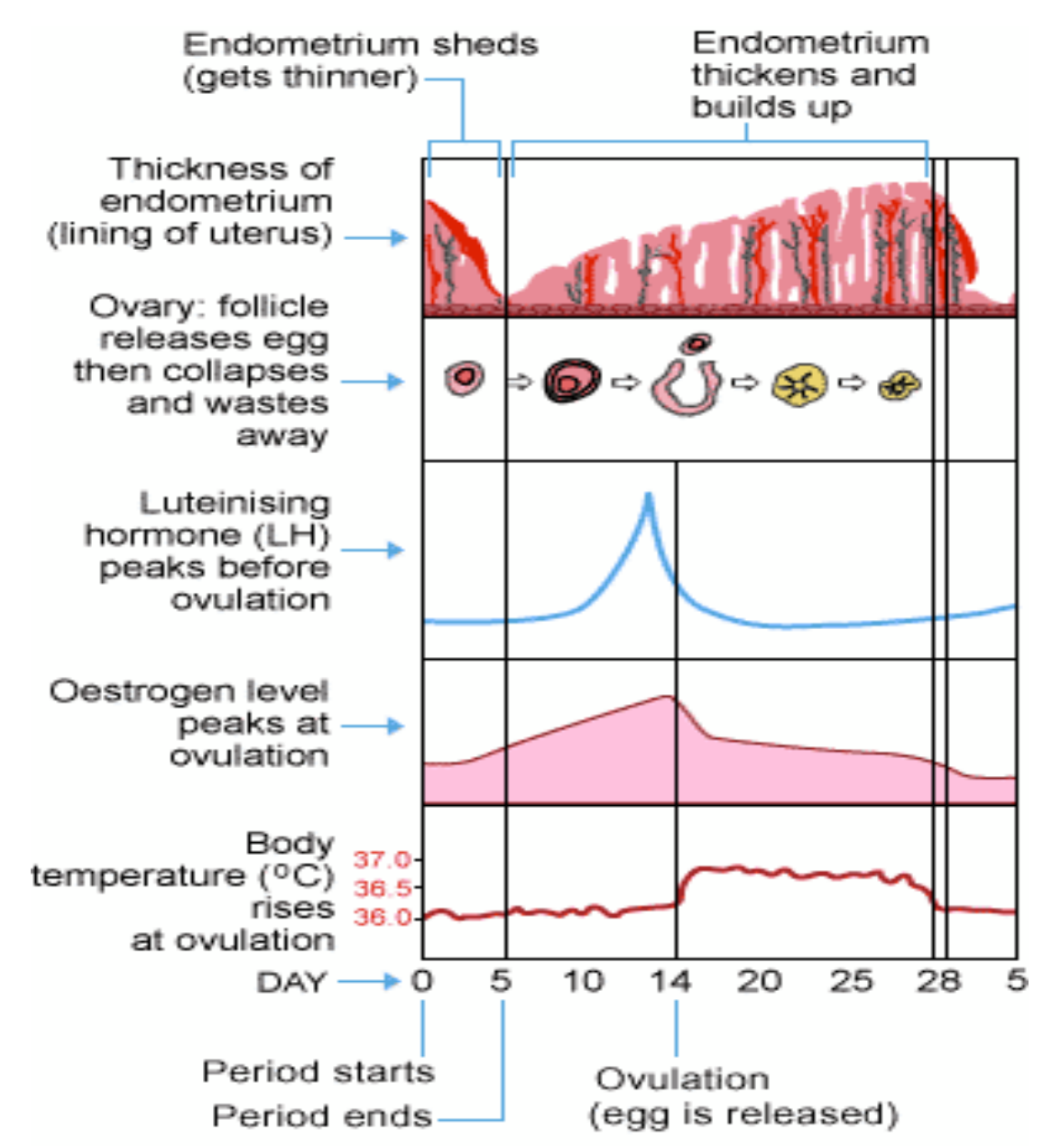




\section{The Menstrual Cycle}

1 Days I-5: Monthly bleeding
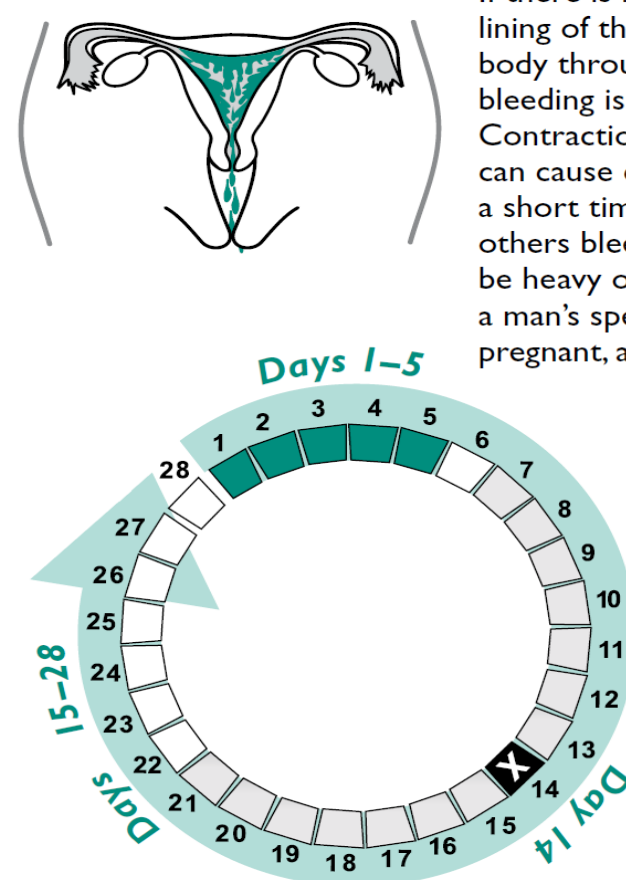

3 Days 15-28:

Thickening of the womb lining

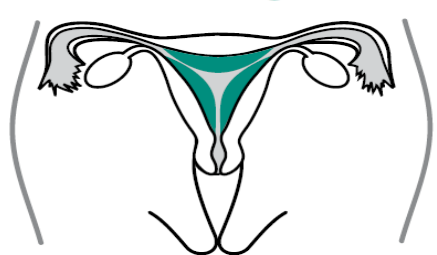

Usually lasts from 2-7 days, often about 5 days

If there is no pregnancy, the thickened lining of the womb is shed. It leaves the body through the vagina. This monthly bleeding is also called menstruation. Contractions of the womb at this time can cause cramps. Some women bleed for a short time (for example, 2 days), while others bleed for up to 8 days. Bleeding can be heavy or light. If the egg is fertilized by man's sperm, the woman may become regnant, and monthly bleeding stops.

Usually about 14 days long, after ovulation

The lining of the uterus (endometrium) becomes thicker during this time to prepare for a fertilized egg. Usually there is no pregnancy, and the unfertilized egg cell dissolves in the reproductive tract. 


\section{Ovulation}

- Hormones and releasing factors affecting ovulation:

- Gonadotropin Releasing Hormone (GnRH).

- Follicle Stimulating Hormone (FSH).

- Luteinizing Hormone (LH).

- Human Chorionic Gonadotropin (HCG).

- Oxytocin. 


\section{Ovulation}

- Estrogen: secreted by the ovaries and responsible for the following:

- Secondary sex characteristics

- Uterine lining development

- Progesterone: secreted by the ovaries and responsible for the following:

- Strongly inhibits $\mathrm{GnRH}$ release (stops production of $\mathrm{LH}$ and $\mathrm{FSH}$ ).

- Uterine lining development (promotes gestation, hence named 'progesterone'). 


\section{Fertilization}

- Male role in fertilization is the ejaculation of the semen (containing sufficient number of motile and normal sperms) out of the male body into the vagina during sexual intercourse.

- Conception:

- It occurs if an active sperm fertilizes the ovum. 


\section{Sexual Desire and the Sexual Response Cycle}

- Sex starts with desire in response to various stimuli like vision, sound, smell, memory, etc...

- Desire is a purely mental process that originates in the brain (not in external genital organs) and is influenced by personal, cultural, ethical and social factors.

- Desire may or may not progress to the next phases of the sexual response cycle i.e. arousal, plateau, orgasm then resolution phases which are the physical reactions to desire. 


\section{Male Genitals}

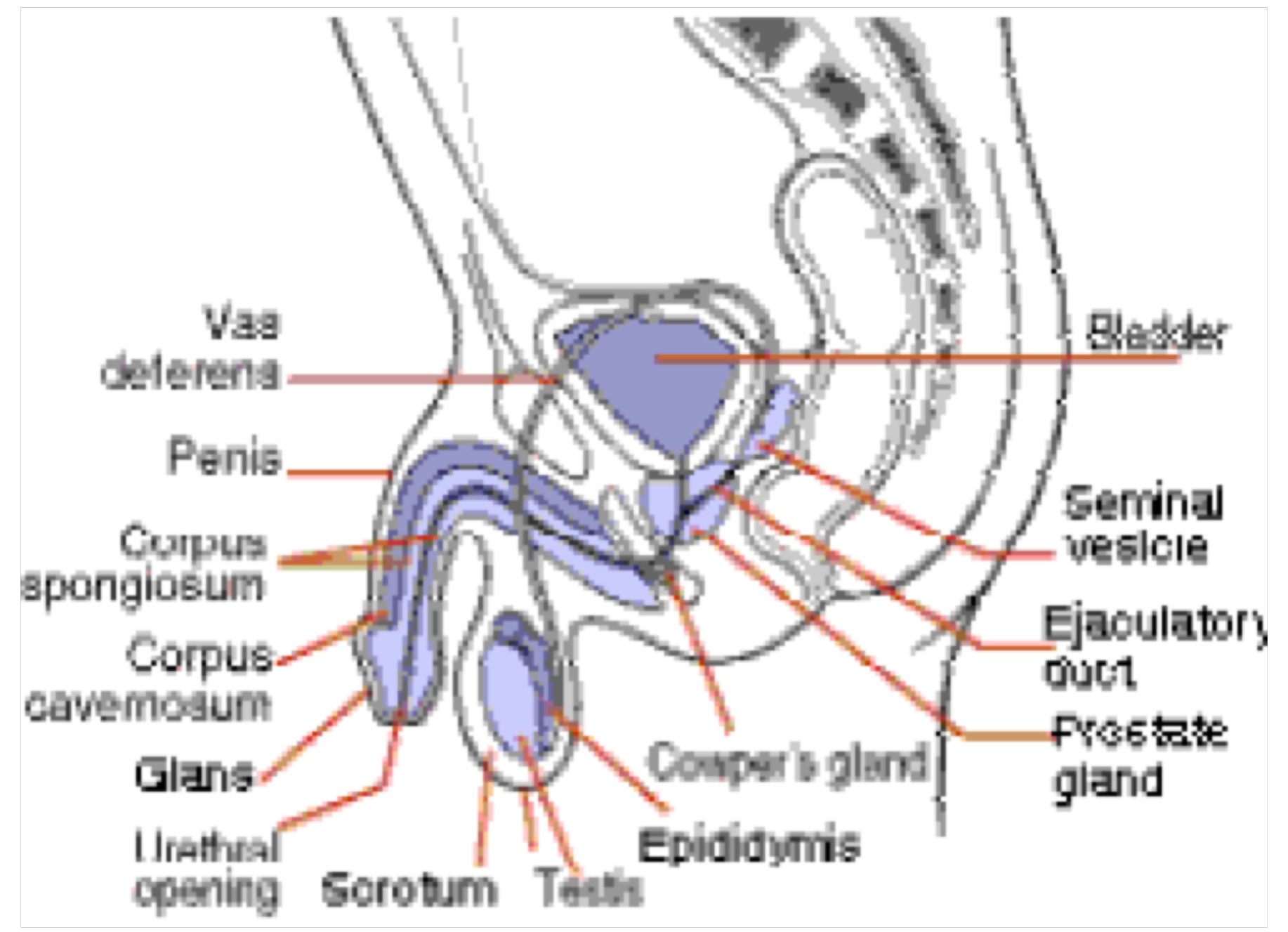




\section{Male Genitals}

- Penis: Cylindrical structure with the capacity to be flaccid or erect, very sensitive to stimulation, provides passage for both urine and semen.

- Glans penis: The most highly innervated part of the penis penetrates the vagina during sex

- Scrotum: A pouch of skin hanging directly under the penis and contains the testes, protects the testes and maintains the temperature necessary for the production of sperms. 


\section{Male Genitals}

- Testicles: Paired, oval-shaped organs located in the scrotum, produce sperms and male sex hormone (testosterone), highly innervated and sensitive to touch and pressure.

- Vas deferens: Paired tubes that carry the mature sperms from the epididymis to the urethra. 


\section{Male Genitals}

- Seminal vesicles: A pair of glandular sacs that secrete about $60 \%$ of the fluid that makes up the semen in which sperms are transported.

- Prostate: Glandular structure that secretes some of the fluid that makes up the semen, the alkaline quality of the fluid neutralizes the acidic environment of the male and female reproductive tracts. 


\section{Client's Clinical Assessment}

- Before examination :It is so important that physician explain the steps of the examination to the woman so she will be prepared and knows what to expect.

- After Examination: it is so important to communicate to the woman your findings and discuss openly her options. 


\section{Client's Clinical Assessment (Cont.)}

- A general medical examination is recommended to:

- All new clients and repeated annually.

- When clients complain of having any side effect.

- A pelvic examination is recommended:

- Before inserting IUDs.

- When clients complain from reproductive tract symptoms. 


\section{General Examination}

History Taking

- Identifying Information: Basic information e.g. Age .... Etc)

- Demographic information: How big Is your family?

- History of present illness: complain and symptoms

- Medical history: what is your current health status, medications used.

- Family Planning History: what are methods used before? For how long? When and why interrupted ? Children spacing? 


\section{General Examination}

History Taking (Cont.)

- Menstrual history: how consistent is the menstrual cycle? what is pattern of the menses?

- Obstetric history: History of operations including deliveries

- Gynecological History: History of visiting a gynecologist, past diagnosis

- Reproductive goals: what are your future goals for your family size and their health status? 


\section{General Examination}

Physical Examination

- Vital signs (measuring blood pressure is a must for all new clients and before hormonal methods resupply every 3 months

- Height

- Weight in $\mathrm{Kg}$

- Overall general condition.

- Head and neck.

- Heart.

- Chest and Lungs.

- Abdominal examination.

- Extremities. 


\section{General Examination}

\section{Documentation}

- All findings, information provided, procedures done, and steps followed must be clearly stated in the Personal file within the family file.

- It has to be done immediately during or after meeting client's need. 


\section{Pelvic Examination}

- Before starting any examination, ensure the privacy of the client and have an open dialogue with the woman about the procedure and the steps.

- At the end of the examination, the doctor should discuss with the woman his findings, consequences, and her future options. 


\section{Pelvic Examination}

\section{External Genitalia}

- Inspect the following structures:

- Mons pubis, observe pubic hair for lice, or other skin lesions

- Labia minora and majora for inflammation, ulcerations, nodules, and female genital mutilation/cutting.

- Inspect the vulva and perineum.

- Observe for any discharge or prolapse, inflammation, ulceration, nodules, previous episiotomy scars, genital warts, or other presentation. 


\section{Pelvic Examination}

\section{Bimanual Examination}

- During bimanual examination, physician must palpate for the following:

- Vagina for cysts or masses.

- Cervix for consistency (soft or firm), mobility (mobile or immobile), tenderness (tender or nontender).

- Supra pubic for tenderness or masses.

- Uterus : size, shape, position, consistency, mobility, and tenderness.

- Adnexa: enlargement, masses or tenderness. 


\section{Bimanual Examination}

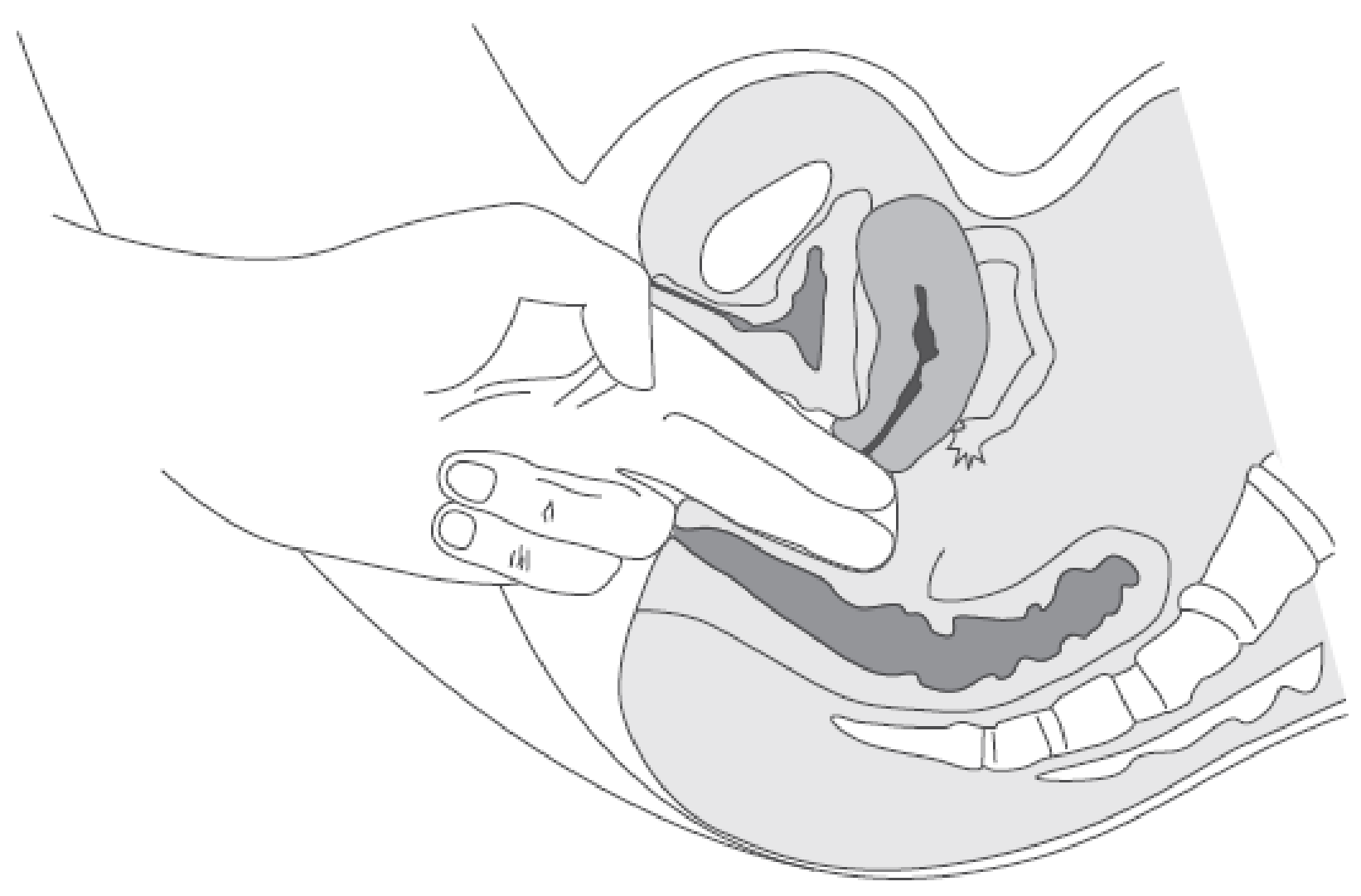




\section{Pelvic Examination}

\section{Speculum Examination}

- Inspect the cervix :

- Observe position, prolapse, transformation zone, ulceration, discharge, polyps, cysts, nodules, color, plaques, and contact bleeding or bleeding from the vagina.

- Abnormal findings include:

- Purulent discharge, Pelvic Inflammatory Disease (PID), Ectropion, Nabothian cyst -Cervicitis, Herpes, Cervical polyp, Cervical carcinoma, Cervical prolapse 


\section{Speculum Examination}

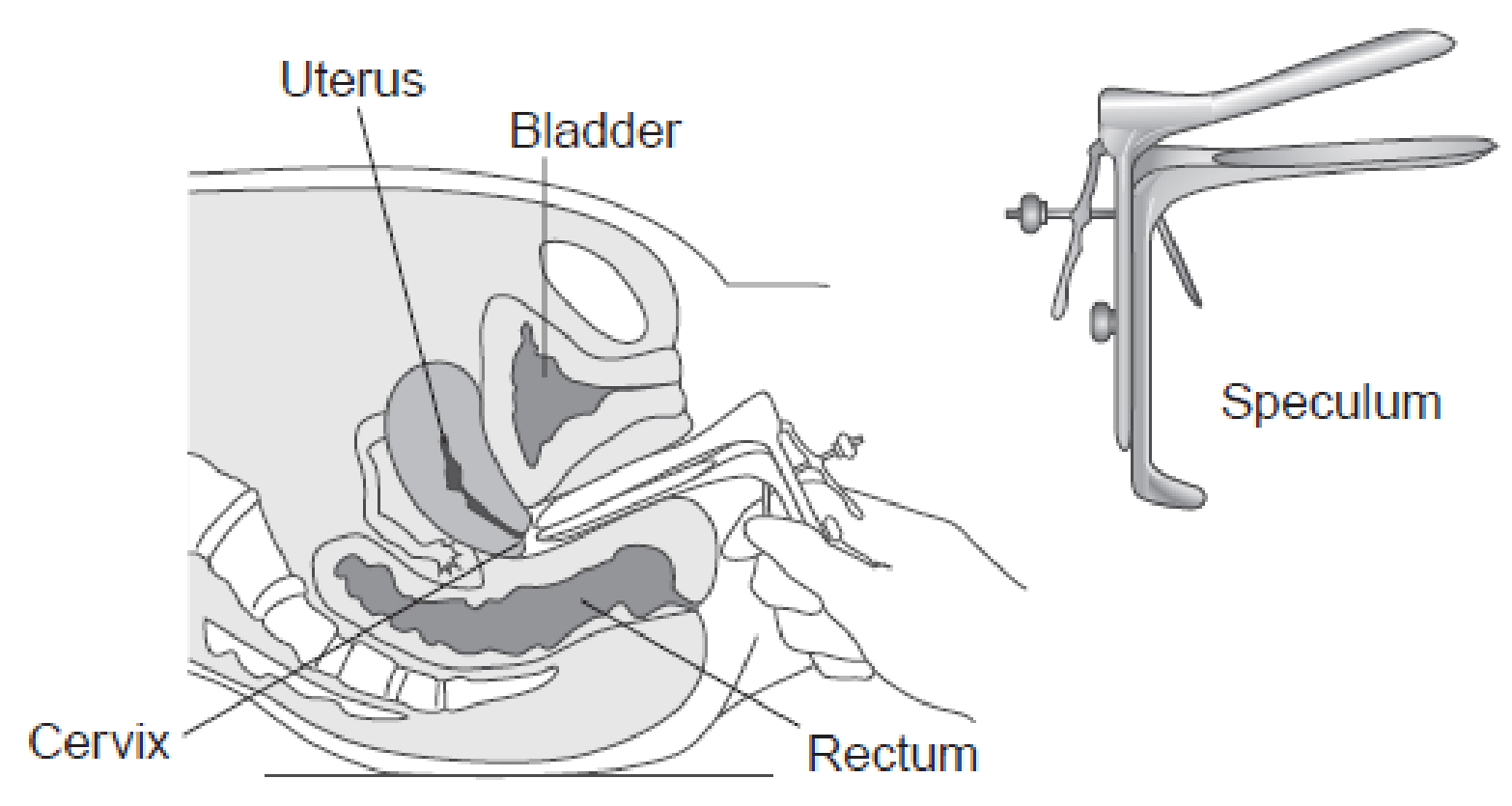


SESSION 4 


\section{Objectives}

- By the end of the session participants will be able to:

- Explain WHO medical eligibility criteria.

- Discuss Combined oral contraceptive pills (COCs), mode of action, how to use, effectiveness, medical eligibility criteria, side effects, and management of selected problems. 


\section{WHO Medical Eligibility Criteria for Contraceptive Use}

- Known medical conditions that might affect eligibility for the use of a contraceptive method are classified into four categories:

\begin{tabular}{|c|l|c|}
\hline Category & \multicolumn{1}{|c|}{ With clinical judgement } & $\begin{array}{c}\text { With limited clinical } \\
\text { judgement }\end{array}$ \\
\hline $\mathbf{1}$ & Use the method under any circumstance & Yes (use the method) \\
\hline $\mathbf{3}$ & $\begin{array}{l}\text { Generally use the method } \\
\text { Use of the method is generally not } \\
\text { recommended other more appropriate } \\
\text { methods are unavailable or unaccepted }\end{array}$ & $\begin{array}{c}\text { No (Do not use the } \\
\text { method) }\end{array}$ \\
\hline $\mathbf{4}$ & Method not to be used \\
\hline
\end{tabular}




\section{WHO Medical Eligibility Criteria for Contraceptive Use}

CATEGORY A condition for which there is no restriction for the use of the 1 contraceptive method.

CATEGORY

2

A condition where the advantages of using the method generally outweigh the theoretical or proven risks.

CATEGORY

3

A condition where the theoretical or proven risks usually outweigh the advantages of using the method.

CATEGORY

4

A condition which represents an unacceptable health risk if the contraceptive method is used. 


\section{WHO Medical Eligibility Criteria for Contraceptive Use}

\begin{tabular}{|l|l|l|}
\hline A & COC & $\begin{array}{l}\text { CATEGORY 3: Without other risk factors for VTE } \\
\text { CATEGORY 4: With other risk factors for VTE }\end{array}$ \\
\hline F & COC & $\begin{array}{l}\text { CATEGORY 2: Without VTE risk factor } \\
\text { CATEGORY 3: With VTE risk factor }\end{array}$ \\
\hline D & $\begin{array}{l}\text { Combined hormonal } \\
\text { injectable }\end{array}$ & CATEGORY 3: With severe liver cirrhosis \\
\hline O & CIC & $\begin{array}{l}\text { CATEGORY 2: In case of Gall Bladder Disease } \\
\text { (medically treated, current/past COC related) }\end{array}$ \\
\hline L & CIC & CATEGORY 2: In case of anticonvulsant and Rifampicin \\
\hline I & Initiation & \\
\hline C & Continuation & \\
\hline
\end{tabular}




\section{WHO Medical Eligibility Criteria for Contraceptive Use}

\begin{tabular}{|c|c|c|c|c|c|}
\hline Condition & $\mathrm{COC} / \mathrm{CIC}$ & POP & DMPA & IMPLANON & CU IUD \\
\hline \multicolumn{6}{|l|}{ Nulliparous } \\
\hline \multicolumn{6}{|c|}{ Breastfeeding } \\
\hline \multicolumn{6}{|l|}{$<6$ weeks post partum } \\
\hline \multicolumn{6}{|l|}{6 weeks to $<6$ months } \\
\hline \multicolumn{6}{|l|}{$>6$ months postpartum } \\
\hline \multicolumn{6}{|c|}{ Postpartum (non-breastfeeding) } \\
\hline$<3$ weeks & A & & & & \\
\hline$>3$ weeks $<6$ weeks & $\mathbf{F}$ & & & & \\
\hline \multicolumn{6}{|c|}{ Postpartum (breastfeeding or non-breastfeeding women, including post caesarean section) } \\
\hline \multicolumn{6}{|l|}{$<48$ hours } \\
\hline \multicolumn{6}{|l|}{48 hours to $<4$ weeks } \\
\hline$>4$ weeks & & & & & \\
\hline
\end{tabular}




\section{WHO Medical Eligibility Criteria for Contraceptive Use}

\begin{tabular}{|c|c|c|c|c|c|}
\hline Condition & COC/CIC & POP & DMPA & IMPLANON & CU IUD \\
\hline Puerperal Sepsis & & & & & \\
\hline \multicolumn{6}{|c|}{ Post Abortion } \\
\hline \multicolumn{6}{|l|}{ First Trimester } \\
\hline \multicolumn{6}{|l|}{ Second Trimester } \\
\hline \multicolumn{6}{|l|}{ Immediate post septic } \\
\hline \multicolumn{6}{|l|}{ Past ectopic pregnancy } \\
\hline \multicolumn{6}{|c|}{ Hypertension } \\
\hline \multicolumn{6}{|l|}{ Adequately controlled } \\
\hline \multicolumn{6}{|c|}{$\begin{array}{l}\text { Consistently elevated blood } \\
\text { pressure level }\end{array}$} \\
\hline \multicolumn{6}{|l|}{$\begin{array}{l}\text { Systolic }>140 \text { to } 159 \text { or } \\
\text { Diastolic }>90 \text { to } 99 \mathrm{mmHg}\end{array}$} \\
\hline $\begin{array}{l}\text { Systolic }>=160 \text { or } \\
\text { Diastolic }>=100 \mathrm{mmHg}\end{array}$ & & & & & \\
\hline
\end{tabular}




\section{WHO Medical Eligibility Criteria for Contraceptive Use}

\begin{tabular}{|l|c|l|l|l|l|}
\hline \multicolumn{1}{|c|}{ Condition } & COC/CIC & POP & DMPA & IMPLANON & CU IUD \\
\hline $\begin{array}{l}\text { History of high blood pressure } \\
\text { during pregnancy (current BP is } \\
\text { normal) }\end{array}$ & & & & & \\
\hline Certain anti convulsant & L & & & & \\
\hline Rifampicin or Refabutin & L & & & & \\
\hline & \multicolumn{2}{|c|}{ Venous Thromboembolism } & & \\
\hline History of VTE & & & & & \\
\hline Current VTE & & & & & \\
\hline $\begin{array}{l}\text { Current VTE (on } \\
\text { anticonvulsants) }\end{array}$ & & & & & \\
\hline $\begin{array}{l}\text { Family history of VTE (first } \\
\text { degree relative) }\end{array}$ & & & & & \\
\hline
\end{tabular}




\section{WHO Medical Eligibility Criteria for Contraceptive Use}

\begin{tabular}{|l|l|l|l|l|l|}
\hline \multicolumn{1}{|c|}{ Condition } & COC/CIC & \multicolumn{1}{c|}{ POP } & \multicolumn{1}{c|}{ DMPA } & IMPLANON & CU IUD \\
\hline \multicolumn{5}{|c|}{ Major Surgery } & \\
\hline With prolonged immobilization & & & & & \\
\hline $\begin{array}{l}\text { Without prolonged } \\
\text { immobilization }\end{array}$ & & & & & \\
\hline $\begin{array}{l}\text { Minor surgery without } \\
\text { immobilization }\end{array}$ & & & & & \\
\hline & & & & & \\
\hline Superficial venous thrombosis & & & & & \\
\hline Varicose veins & & & & & \\
\hline Superficial thrombophlebitis & & & & & \\
\hline
\end{tabular}




\section{WHO Medical Eligibility Criteria for Contraceptive Use}

\begin{tabular}{|c|c|c|c|c|c|c|}
\hline Condition & $\mathrm{COC} / \mathrm{ClC}$ & \multicolumn{2}{|c|}{ POP } & DMPA & IMPLANON & CU IUD \\
\hline $\begin{array}{l}\text { Current and history of ischemic } \\
\text { heart disease or stroke }\end{array}$ & & 1 & C & & & \\
\hline \multicolumn{7}{|c|}{ Vulvar and Congenital Heart Disease } \\
\hline \multicolumn{7}{|l|}{ Uncomplicated } \\
\hline \multicolumn{7}{|l|}{ Complicated } \\
\hline \multicolumn{7}{|c|}{ Migraine Headaches* } \\
\hline \multicolumn{7}{|l|}{ Without Aura, age $<35$ years } \\
\hline \multicolumn{7}{|l|}{ Without Aura, age $>=35$ years } \\
\hline \multicolumn{7}{|l|}{ With Aura, any age } \\
\hline Iron deficiency & & & & & & \\
\hline
\end{tabular}




\section{WHO Medical Eligibility Criteria for Contraceptive Use}

\begin{tabular}{|c|c|c|c|c|c|c|}
\hline Condition & $\mathrm{COC} / \mathrm{ClC}$ & POP & DMPA & IMPLANON & \multicolumn{2}{|c|}{ CU IUD } \\
\hline \multicolumn{7}{|c|}{ Gall Bladder Disease } \\
\hline \multicolumn{7}{|l|}{ Treated by cholecystectomy } \\
\hline Medically treated & 0 & & & & & \\
\hline Current & 0 & & & & & \\
\hline $\begin{array}{l}\text { Past history of cholestasis - } \\
\text { COC related }\end{array}$ & 0 & & & & & \\
\hline \multicolumn{7}{|c|}{ Vaginal Bleeding Patterns } \\
\hline \multicolumn{7}{|l|}{$\begin{array}{l}\text { Irregular pattern without } \\
\text { heaving bleeding }\end{array}$} \\
\hline \multicolumn{7}{|l|}{$\begin{array}{l}\text { Heavy or prolonged bleeding } \\
\text { (includes regular/irregular } \\
\text { patterns) }\end{array}$} \\
\hline $\begin{array}{l}\text { Unexplained vaginal bleeding } \\
\text { before ovulation }\end{array}$ & & & & & 1 & C \\
\hline
\end{tabular}




\section{WHO Medical Eligibility Criteria for Contraceptive Use}

\begin{tabular}{|l|l|l|l|l|l|}
\hline \multicolumn{1}{|c|}{ Condition } & COC/CIC & POP & DMPA & IMPLANON & \multicolumn{1}{c|}{ CU IUD } \\
\hline Endometriosis & & & & & \\
\hline $\begin{array}{l}\text { Benign ovarian tumors } \\
\text { (including cysts) }\end{array}$ & & & & & \\
\hline Severe dysmenorryhoea & & & & & \\
\hline $\begin{array}{l}\text { Cervical cancer (awaiting } \\
\text { treatment) }\end{array}$ & & & & & \\
\hline \multicolumn{2}{|c|}{ Breast Disease } & & & \\
\hline Undiagnosed mass & & & & & \\
\hline Benign breast mass & & & & & \\
\hline Family history of cancer & & & & & \\
\hline Current breast cancer & & & & & \\
\hline
\end{tabular}




\section{WHO Medical Eligibility Criteria for Contraceptive Use}

\begin{tabular}{|c|c|c|c|c|c|c|}
\hline Condition & $\mathrm{COC} / \mathrm{CIC}$ & POP & DMPA & IMPLANON & \multicolumn{2}{|c|}{ CU IUD } \\
\hline Endometrial Cancer & & & & & I & C \\
\hline Ovarian Cancer & & & & & & \\
\hline \multicolumn{7}{|c|}{ Uterine fibroids } \\
\hline \multicolumn{7}{|l|}{$\begin{array}{l}\text { Without distortion of the uterine } \\
\text { cavity }\end{array}$} \\
\hline \multicolumn{7}{|l|}{$\begin{array}{l}\text { With distortion of the uterine } \\
\text { cavity }\end{array}$} \\
\hline \multicolumn{7}{|c|}{ Pelvic Inflammatory Disease } \\
\hline \multicolumn{7}{|l|}{ Past history } \\
\hline $\begin{array}{l}\text { PID-current or within the last } 3 \\
\text { months }\end{array}$ & & & & & I & $\mathrm{C}$ \\
\hline
\end{tabular}




\section{WHO Medical Eligibility Criteria for Contraceptive Use}

\begin{tabular}{|c|c|c|c|c|c|c|}
\hline Condition & $\mathrm{COC} / \mathrm{ClC}$ & POP & DMPA & IMPLANON & \multicolumn{2}{|c|}{ CU IUD } \\
\hline \multicolumn{7}{|c|}{ STIS } \\
\hline $\begin{array}{l}\text { Purulent cervicitis, chlamydia or } \\
\text { gonorrhea }\end{array}$ & & & & & 1 & C \\
\hline \multicolumn{7}{|l|}{$\begin{array}{l}\text { Vaginitis (including trichomonas } \\
\text { vaginalis and bacterial } \\
\text { vaginosis) }\end{array}$} \\
\hline \multicolumn{7}{|l|}{ Increased risk of STIs } \\
\hline \multicolumn{7}{|c|}{ Tuberculosis } \\
\hline \multicolumn{7}{|l|}{ Non pelvic } \\
\hline Pelvic & & & & & I & $\mathrm{C}$ \\
\hline \multicolumn{7}{|c|}{ Diabetes } \\
\hline \multicolumn{7}{|l|}{ Non vascular disease } \\
\hline \multicolumn{7}{|l|}{ Retinopathy - Nephropathy } \\
\hline Diabetes $>20$ years duration & & & & & & \\
\hline
\end{tabular}




\section{WHO Medical Eligibility Criteria for Contraceptive Use}

\begin{tabular}{|c|c|c|c|c|c|}
\hline Condition & $\mathrm{coc} / \mathrm{ClC}$ & POP & DMPA & IMPLANON & CU IUD \\
\hline \multicolumn{6}{|c|}{ Thyroid Disorders } \\
\hline \multicolumn{6}{|l|}{ Hyperthyroid } \\
\hline \multicolumn{6}{|l|}{ Hypothyroid } \\
\hline \multicolumn{6}{|c|}{ Viral Hepatitis } \\
\hline Acute or flare & C & & & & \\
\hline \multicolumn{6}{|l|}{ Carrier } \\
\hline \multicolumn{6}{|c|}{ Liver Cirrhosis } \\
\hline \multicolumn{6}{|l|}{ Mild (compensated) } \\
\hline Severe (decompensated) & D & & & & \\
\hline
\end{tabular}




\section{Combined Oral Contraceptives (COCs)}

- What are combined oral contraceptives? Pills that contain low doses of 2 hormones -a progestin and estrogen like the natural hormones progesterone and estrogen in a woman's body.

- Brands available in the Market :

- Microcept (0.03 mg ethinylestradiol, 0.15 mg levonorgestrel )

- Triocept

- Cilest

- Genera

- Marvelon

- Yasmeen 


\section{Combined Oral Contraceptives (cont.)}

- Mechanism of action: COCs prevent pregnancy essentially by

- Preventing ovulation.

- Partially by increasing the viscosity of the cervical mucus making it difficult to be penetrated by sperms.

- Effectiveness:

- When no pill- taking mistakes are made (with regular use), less than 1 pregnancy per 100 women using COCs over the first year (3 per 1000 women). 


\section{Combined Oral Contraceptives}

Advantages

- Safe and highly effective when taken correctly and consistently.

- Reversible.

- No action needed at time of intercourse.

- Reduces menstrual irregularities, anemia , painful menses.

- Reduces risk of ovarian and uterine cancer. 


\section{Combined Oral Contraceptives}

\section{Disadvantages}

- Requires daily administration.

- Not recommended during breastfeeding women as it affects the quantity of breast milk, yet they can be used after 6 months of child birth. 


\section{Combined Oral Contraceptives}

Side Effects

- Some users report the following :

- Changes in bleeding patterns including:

- lighter bleeding and fewer days of bleeding

- Irregular bleeding

- No monthly bleeding

- Headaches, dizziness, nausea, breast tenderness, weight gain, and mood changes. 


\section{Combined Oral Contraceptives}

\section{Who can Use}

Nearly all women can use COCs safely and effectively, including those who:

- Have or have not children.

- Are of any age, including married adolescents and women over 40 years old.

- Have just had an abortion or miscarriage.

- Smoke cigarettes if under 35 years old.

- Have anemia now or had in the past.

- Have varicose veins.

- Are infected with HIV, whether or not on antiretroviral therapy, unless that therapy includes Ritonavir. 


\section{Combined Oral Contraceptives}

\section{Who can't use}

- Category 3 - 4 of WHO medical eligibility criteria

- Women breast feeding baby less than 6 months old.

- Women who had a baby in the last 3 weeks and are not breastfeeding.

- Women with an additional risk that she might develop a blood clot in a deep vein, then she should not start COCs at 3 weeks after child birth, but better start at 6 weeks instead (previous VTE, thrombophilia, caesarean delivery, blood transfusion at delivery, postpartum hemorrhage, pre-eclampsia, obesity $>30 \mathrm{~kg} / \mathrm{m} 2$, smoking, and being bedridden for a prolonged time). 


\section{Combined Oral Contraceptives}

Who can't Use (cont.)

- Women who smoke cigarettes, If they are 35 years of age or older.

- Women who have cirrhosis of the liver, or liver tumors. Those should choose a method without hormones.

- Have blood pressure 140/90mmHg or higher.

- Have had diabetes for more than 20 years and its complications, or with diabetes less than 20 years but with complications.

- Have gallbladder disease now or are taking medication for gallbladder disease.

- Have had a stroke, blood clot in their leg or lungs, heart attack, or other serious heart problems. 


\section{Combined Oral Contraceptives}

Who can't Use (cont.)

- Have or have had breast cancer, they choose a method without hormones.

- Have migraine headaches.

- Are taking medication for seizures, or Rifampicin for tuberculosis or other illness.

- Are planning major surgery that will keep them from walking for one week or more.

- Have several conditions that could increase their chances of heart disease (coronary artery disease) or stroke such as older age- smoking - diabetes or high blood pressure $\geq 140 / 90 \mathrm{mmg}$. 


\section{Combined Oral Contraceptives}

\section{When to start}

- A woman can start using COCs any time if it is reasonably certain she is not pregnant (pregnancy checklist).

- Any time of the month :

- If she is starting within5 days after the start of her monthly bleeding, no need for a backup method.

- If it is more than 5 days after the start of her monthly bleeding, she can start COCs any time it is reasonably certain she is not pregnant, but she will need a backup method for the first 7 days of taking pills.

- Switching from a hormonal method : immediately if she has been using the method consistently and correctly. 


\section{Combined Oral Contraceptives}

When to Start (cont.)

- Fully or nearly fully breastfeeding:

- More than 6 months after giving birth

- If her monthly bleeding has not returned she can start using COCs any time if it is reasonably certain she is not pregnant, but she will need a backup method for the first 7 days of taking pills.

- If her monthly bleeding has returned she can start COCs as advised for women having menstrual cycles. 


\section{Combined Oral Contraceptives}

When to Start (cont.)

- Not breastfeeding :

- She start COCs at any time on days 21-28 after giving birth.

- More than 4 weeks after giving birth : if her monthly bleeding has not returned she can start COCs any time if it is reasonably certain she is not pregnant, but she will need a backup method for the first 7 days of taking pills.

- If her monthly bleeding has returned she can start COCs as advised for women having menstrual cycles. 


\section{Combined Oral Contraceptives}

When to Start (cont.)

- After miscarriage or abortion:

- Immediately if she is starting within 7 days after first or second trimester miscarriage or abortion no need for a backup method.

- If it is more than 7 days after first or second trimester miscarriage or abortion she can start cOCs any time if it is reasonably certain she is not pregnant, but she will need a backup method for the 7 days of taking pills. 


\section{Managing Missed Pills}

- Key Message:

- Take a missed hormonal pill as soon as possible.

- Keep taking pills as usual, one each day (She may take 2 pills at the same time or on the same day.) 


\section{Managing Missed Pills}

\begin{tabular}{|c|c|}
\hline Scenario & Action taken \\
\hline $\begin{array}{l}\text { Missed } 1 \text { or } 2 \text { pills/ Started } \\
\text { new pack } 1 \text { or } 2 \text { days late }\end{array}$ & $\begin{array}{l}\text { - Take a hormonal pill as soon as possible. } \\
\text { - Little or no risk of pregnancy. }\end{array}$ \\
\hline $\begin{array}{l}\text { Missed pills } 3 \text { or more days in } \\
\text { a row in the first or second } \\
\text { week/ Started new pack } 3 \text { or } \\
\text { more days late }\end{array}$ & $\begin{array}{l}\text { - Take a hormonal pill as soon as possible. } \\
\text { - Use a backup method for the next } 7 \text { days. } \\
\text { Also, if she had sex in the past } 5 \text { days, can } \\
\text { consider ECPs (see Emergency Contraceptive } \\
\text { Pills) }\end{array}$ \\
\hline
\end{tabular}




\section{Managing Missed Pills (cont.)}

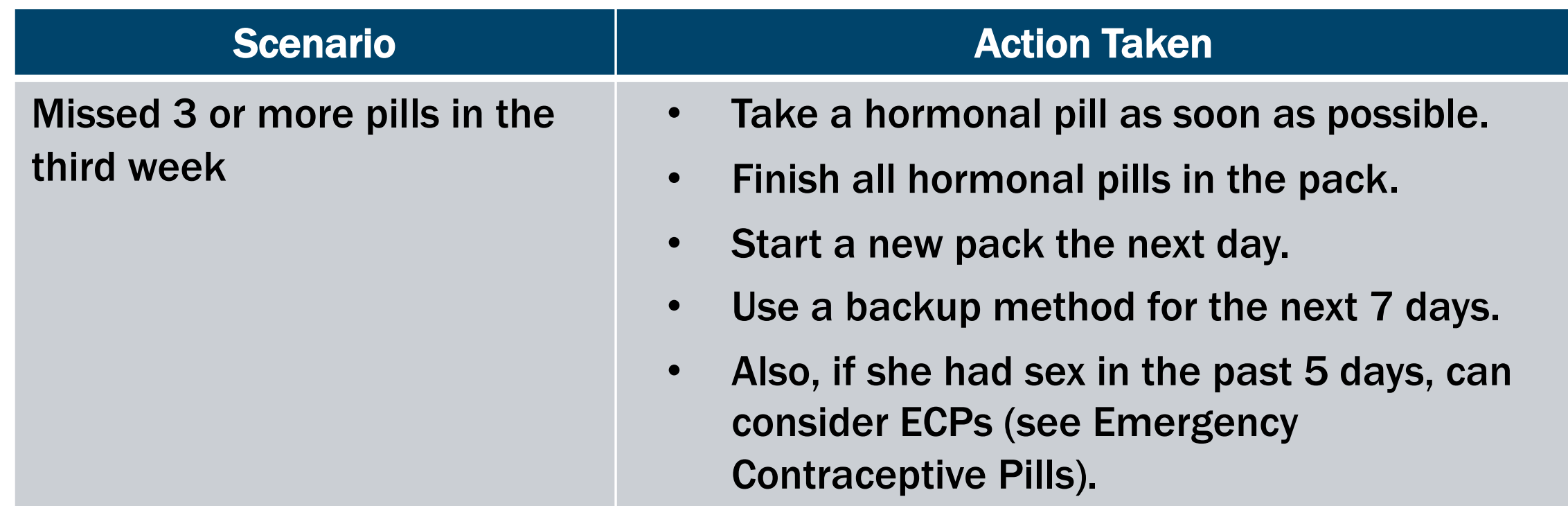

Managing the missed effect of

- If she vomits within 2 hours after taking a pill, a pills due to Severe vomiting or diarrhea she should take another pill from her pack as soon as possible, then keep taking pills as usual.

- If she has vomiting or diarrhea for more than 2 days, follow instructions for 3 or more missed pills, above 


\section{Managing Problems Associated with COCs}

Problem

Irregular bleeding

\section{Action taken}

- Reassure client ( becomes less or stop after the first few cycles ).

- Advise taking the pills at the same time every day.

- Exclude vomiting, diarrhea or taking other medications.

- Teach her how to take missed pills.

- Try $800 \mathrm{mg}$ Ibuprofen or other NSAID at $\mathbf{3}$ times daily for 5 days.

- Try other formula of COCs.

- If irregular bleeding continues, consider other underlying conditions not related to method use. 


\section{Managing Problems Associated with COCs (cont.)}

\begin{tabular}{|l|l|}
\hline \multicolumn{1}{|c|}{ Problem } & \multicolumn{1}{c|}{ Action taken } \\
\hline No monthly bleeding & - Reassure client. \\
& - Ask if she has been taking a pill every day. \\
& - Did she skip the 7 days break. \\
& - Advise on how to take missed pills. \\
& - Exclude pregnancy. \\
\hline Ordinary Headache & - Suggest Aspirin, NSAIDs or paracetamol. \\
\hline Breast tenderness & - Evaluate \\
\hline Nausea or dizziness & - Wear supportive bra. \\
\hline
\end{tabular}




\section{Managing Problems Associated with COCs (cont.)}

\begin{tabular}{|c|c|}
\hline Problem & Action taken \\
\hline $\begin{array}{l}\text { Mood changes or } \\
\text { change in sex desire }\end{array}$ & $\begin{array}{l}\text { - Check if there are changes in her life } \\
\text { affecting her mood. } \\
\text { - Refer for evaluation. }\end{array}$ \\
\hline Acne & $\begin{array}{l}\text { - Usually improves with COCs. } \\
\text { - Give different formula for at least } 3 \text { months }\end{array}$ \\
\hline $\begin{array}{l}\text { Unexplained Vaginal } \\
\text { bleeding }\end{array}$ & $\begin{array}{l}\text { Refer for evaluation by history and pelvic } \\
\text { exam. } \\
\text { - Diagnose and treat as appropriate. } \\
\text { - Do not stop COCs during evaluation. } \\
\text { - Treat PID or STIs if exists without stopping } \\
\text { pills. }\end{array}$ \\
\hline
\end{tabular}




\section{Managing Problems Associated with COCs (cont.)}

Problem

Migraine headaches

Conditions in which client will be unable to move for several weeks ( major surgery or her leg in a cast)

Suspected pregnancy

\section{Action taken}

- Stop COCs.

- Help her choose a method that does not include estrogen.

- Tell her doctor that she is using COCs.

- Stop COCs during this period and use a backup method .

- Start COCs 2 weeks after she can move again

- Assess for pregnancy .

- Stop taking COCs if pregnancy is confirmed.

- No known risks to the fetus. 


\section{Managing Problems Associated with COCs (cont.)}

\section{Problem}

Certain serious health conditions

( heart and liver disease, high blood pressure , DVT, stroke, breast cancer, complicated DM, clots in the lung):

Weight gain:

\section{Action taken}

- Stop taking COCs.

- Use a backup method (e.g. condom, spermicides).

- Refer for diagnosis and care. 


\section{Follow-up}

- After the first prescription, the client should be seen after three months for pill re-supply.

- Annual examination should be encouraged.

- The client should report immediately to the clinic if she experiences:

- Severe chest pain.

- Severe headache.

- Severe pain in the legs. 
SESSION 5 


\section{Objectives}

- By the end of the session the participant will be able to:

- Discuss effectiveness, how to use, side effects and medical eligibility criteria of progestin only pills and injectable methods (combined and progestine only) as well as common problems and its management.

- Identify common rumors about oral contraceptive pills, injectables and implants and how to respond to it

- Discuss types and how to use emergency contraception. 


\section{Progestin-Only Pills (POPs)}

- What are progestin only pills? Pills that contain very low doses of a progestin like the natural hormone progesterone in a woman's body.

- Mechanism of action:

- They make the cervical mucus thicker, thus prevent sperms from ascending to meet the ovum.

- Occasionally they prevent ovulation.

- Brands available in the Market :

- Microlut

- Exluton

- Levonor 


\section{Progestin-Only Pills}

\section{Effectiveness}

- Breastfeeding women:

- As commonly used, about 1 pregnancy per 100 women using POPs over the first year.

- When pills are taken every day, less than 1 pregnancy per 100 women using POPs over the first year(3 per 1,000women).

- Non breastfeeding Less effective :

- As commonly used, about 3 to 10 pregnancies per 100 women using POPs over the first year.

- When pills are taken every day at the same time, less than 1 pregnancy per 100 women using POPs over the first year (9 per 1,000 women). 


\section{Progestin-Only Pills}

Advantages

- Can be used by breastfeeding women, does not affect quality or quantity of milk.

- Easy to use, one is taken every day continuously.

- Does not contain estrogen which is contraindicated for some woman.

- May help prevent uterine and ovarian cancer. 


\section{Progestin-Only Pills}

\section{Disadvantages}

- Pills must be taken at same time every day.

- Incorrect pill intake and missing a pill significantly reduces efficacy, particularly among non- breastfeeding women. 


\section{Progestin-Only Pills}

\section{Side Effects}

- Some users report the following:

- Changes in bleeding patterns especially among breast feeding women:

- Delay in return of monthly bleeding after childbirth.

- Frequent or irregular or prolonged bleeding.

- No monthly bleeding.

- Headaches.

- Dizziness, nausea, mood changes.

- Breast tenderness.

- Abdominal pain.

- Other possible physical changes among non breastfeeding women for e.g. enlarged ovarian follicles. 


\section{Progestin-Only Pills}

Who can't Use

- Category 3 - 4 of WHO of medical eligibility criteria; women who:

- Have severe liver cirrhosis, liver infection or liver tumor.

- Have a blood clot in their legs or lungs.

- Are taking medication for seizures, or Rifampicin or Rifabutin for tuberculosis or other illness.

- Have or have ever had breast cancer. 


\section{Progestin-Only Pills}

\section{When to Start}

- A woman can start using POPs any time if it is reasonably certain she is not pregnant (pregnancy checklist).

- Among menstruating women : if she is starting within 5 days after the start of her monthly bleeding, no need for a backup method.

- No monthly bleeding, or more than 5 days after the start of her monthly bleeding she can start POPs any time if it is reasonably certain she is not pregnant, she will need a backup method for the first 2 days of taking pills. 


\section{Progestin-Only Pills}

When to Start (cont.)

- Fully or nearly fully breastfeeding.

- She can start after giving birth.

- If her monthly bleeding has not returned, and fully lactating she can start POPs with no need for a backup method.

- If her monthly bleeding has returned she can start POPs as advised for women having menstrual cycles. 


\section{Progestin-Only Pills}

When to Start (cont.)

- Non breastfeeding women:

- Less than 4 weeks after giving birth: she can start POPs any time no need for a backup method.

- More than 4 weeks after giving birth: if her monthly bleeding has not returned, she can start POPs any time if it is reasonably certain she is not pregnant she will need a backup method for the first 2 days of taking pills.

- If her monthly bleeding has returned she can start POPs as advised for menstruating women. 


\section{Progestin-Only Pills}

When to Start (cont.)

- Switching from a hormonal method:

- She can start immediately if she has been using the method consistently and correctly.

- After miscarriage or abortion:

- She can start immediately if she is starting within 7 days after first or second trimester miscarriage or abortion with no need for a backup method.

- if it is more than 7 days after first or second trimester miscarriage or abortion she can start POPs any time if it is reasonably certain she is not pregnant, but she will need a backup method e.g. condom for 2 days of taking pills. 


\section{Progestin-Only Pills}

How to Use

- Take one pill every day at the same time (it is recommended not to be delayed for more than 3 hours).

- No break between packs. 


\section{Progestin-Only Pills}

\section{Managing Missed}

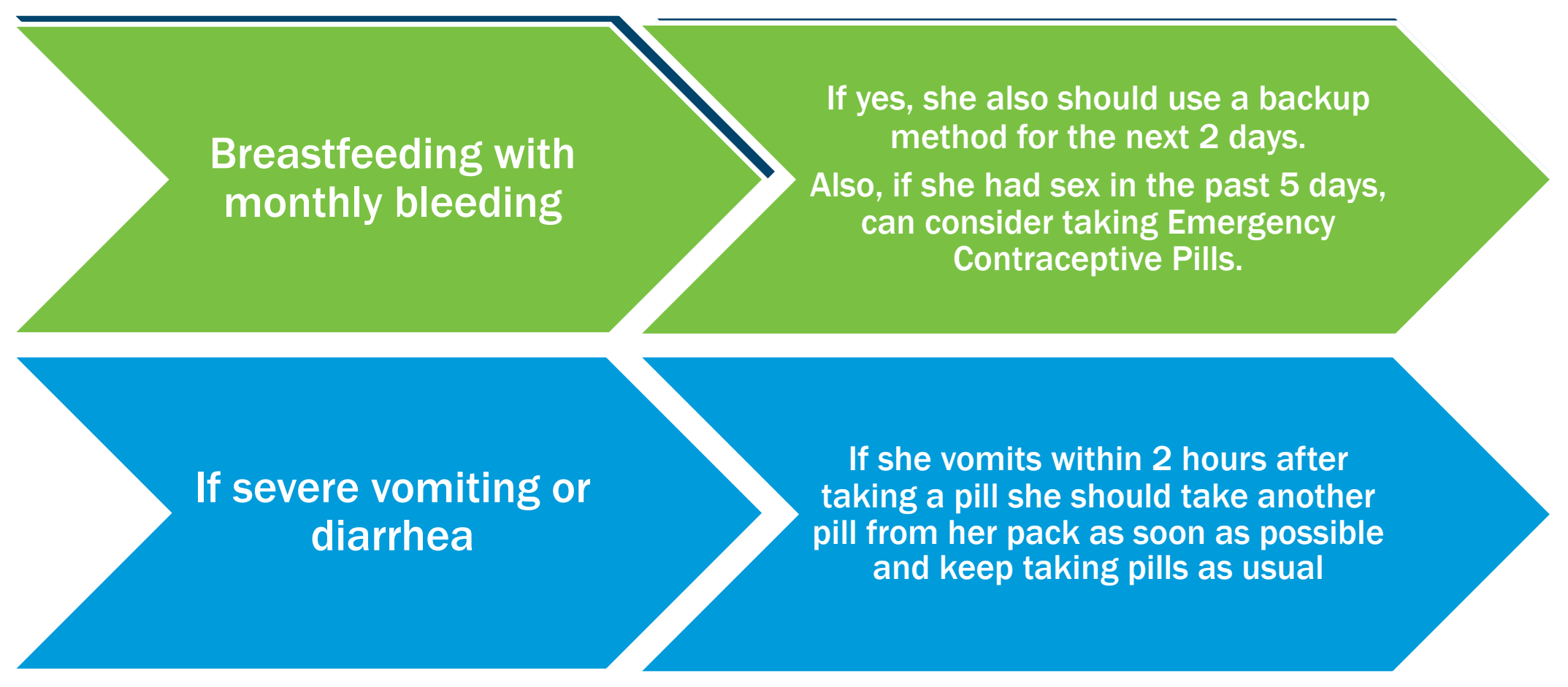




\section{Progestin-Only Pills}

Managing Problems

\begin{tabular}{|l|l|}
\hline \multicolumn{1}{|c|}{ Problem } & \multicolumn{1}{c|}{ Action taken } \\
\hline Irregular bleeding: & - $\begin{array}{l}\text { Reassure woman, it is common and may } \\
\text { stop after few months. }\end{array}$ \\
\hline & Emphasis that pills must be taken at the \\
same time every day. \\
- Exclude vomiting, diarrhea, anticonvulsants \\
and Rifampicine . \\
- Take missed pills properly including after \\
vomiting and diarrhea. \\
- Try lbuprofen 800 mg 3 times for 5 days or \\
other NSAIDs. \\
- Try other POPs formula for 3 months . \\
- Consider other underlying conditions not \\
related to method use.
\end{tabular}




\section{Progestin-Only Pills}

Managing Problems

\begin{tabular}{|c|c|}
\hline Problem & Action taken \\
\hline $\begin{array}{l}\text { Heavy or prolonged } \\
\text { bleeding: }\end{array}$ & $\begin{array}{l}\text { - } \text { Reassure client. } \\
\text { - } \text { Try NSAIDs. } \\
\text { - } \text { Provide iron tableeds to prevent anemia. } \\
\text { underlying continues ,consider other } \\
\text { undions. }\end{array}$ \\
\hline $\begin{array}{l}\text { Head aches, mood } \\
\text { changes and changes } \\
\text { in sex drive }\end{array}$ & $\begin{array}{l}\text { - Check if there are changes in her life } \\
\text { affecting her mood or sexual desire. } \\
\text { - Refer to evaluation. }\end{array}$ \\
\hline No monthly bleeding & $\begin{array}{l}\text { - } \quad \text { Normal during breast feeding . } \\
\text { mot breast feeding, reassure ( common in } \\
\text { manen and it is not harmful ). }\end{array}$ \\
\hline
\end{tabular}




\section{Progestin-Only Pills}

Managing Problems

\section{Problem}

Unexplained vaginal bleeding:

Migraine:

\section{Action taken}

- Refer for evaluation by history and pelvic exam and treat as appropriate.

- Do not stop POPs.

- Treat PID or STIs if they exist.

- She may continue with POPs if no aura.

- If she has migraine aura, stop POPs and give non hormonal method.

- If Serious health conditions are suspected e.g. blood clots in deep veins of legs or lung, liver disease or breast cancer).

- Stop POPs, give backup method and refer for diagnosis and care. 


\section{Progestin-Only Pills}

Managing Problems

\begin{tabular}{|c|c|}
\hline Problem & Action taken \\
\hline $\begin{array}{l}\text { Severe lower } \\
\text { abdominal pain: }\end{array}$ & $\begin{array}{l}\text { May be due to several problems such as } \\
\text { enlarged ovarian follicles or cysts. } \\
\text { - Continue POPs during evaluation. } \\
\text { - Reassure that cysts will disappear and } \\
\text { evaluate after } 6 \text { months. } \\
\text { - Exclude ectopic pregnancy although POPs } \\
\text { do not cause ectopic pregnancy. } \\
\text { - Refer for immediate diagnosis and care if } \\
\text { you suspect ectopic pregnancy or other } \\
\text { serious conditions. }\end{array}$ \\
\hline Suspected pregnancy : & $\begin{array}{l}\text { Assess for pregnancy including ectopic. } \\
\text { - Stop POPs. } \\
\text { - Assure client that no known risk to fetus. }\end{array}$ \\
\hline
\end{tabular}




\section{Combined (Monthly) Injectables}

- What are monthly injectable?

- Monthly injectable contain 2 hormones (progestin and an estrogen) like the natural hormones progesterone and estrogen in a woman's body.

- Available brands in the market:

- Mesocept ampoule.

- Contain 50 mg Norethisterone enanthate + 5 mg estradiol valerate 


\section{Combined Injectables (cont.)}

- Mechanism of action, advantages, disadvantages and side effects are similar to those of COCs.

- How effective?

- Risk of pregnancy is greatest when a woman is late for an injection or misses it.

- When women have injection regularly on a monthly basis, less than 1 pregnancy per 100 women using injection over the first year (5 per 10.000 women )

- Return of fertility after injections are stopped, it takes an average of about one month longer than with most other methods. 


\section{Combined Injectables}

When to Start

- A woman can start monthly injectable like cOCs:

- If she is menstruating, she can start within 7 days after the start of her monthly bleeding and no need for a backup method.

- If it is more than 7 days after the start of her monthly bleeding she can start any time it is reasonably certain she is not pregnant but she will need a backup method for the first 7 days after the injection. 


\section{Combined Injectables (cont.)}

- Planning the next injection:

- Every 4 weeks, she should come on time, however she may come 7 days early or late and still get an injection.

- Management of problems:

- Irregular bleeding:

- Reassure her that many women experience irregular bleeding, it is not harmful and usually becomes less or stops after the first few months of use. 


\section{Progestin-only Injectables}

- What are progestin only (3-month ) injectables?

- The injectable contraceptive Depot medroxyprogesterone acetate $150 \mathrm{mg}$ (DMPA) contains a progestin like the natural hormone progesterone in a woman's body, it is known as Depo-provera.

- It is taken every 3 months.

- Mechanism of action:

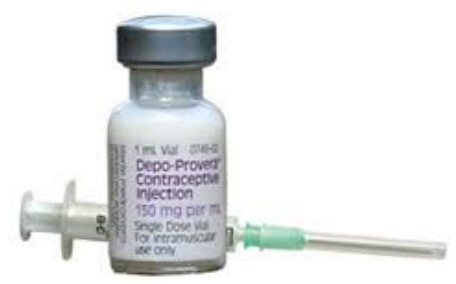

- The cervical mucus become thick and prevents sperm ascending to meet the ovum.

- Occasionally it prevents ovulation. 


\section{Progestin-only Injectables}

\section{Effectiveness}

- Taking injections regularly every 3 months is important to achieve the greatest effectiveness.

- User should be instructed to come every 3 months for subsequent injections, however she may come 2 weeks early or 4 weeks late and still get an injection.

- When women have injections regularly every 3 months, less than 1 pregnancy per 100 women using progestin only injectables over the first year (3per 1000 women ).

- Return of fertility after injections are stopped: an average about 4-9 months longer for DMPA than with most other methods. 


\section{Progestin-only Injectables}

\section{Side Effects}

- Some users report the following:

- Changes in bleeding patterns:

- First 3 months: irregular bleeding or prolonged bleeding.

- At one year: no monthly bleeding or irregular bleeding.

- Weight gain, headaches, dizziness, abdominal bloating and discomfort, mood changes and reduced sex drive.

- Other possible physical changes: loss of bone density. 


\section{Progestin-only Injectables}

\section{Benefits}

- Helps protect against: risks of pregnancy, uterine fibroids, endometrium and ovarian cancer.

- May help protect against: symptomatic pelvic inflammatory disease and iron deficiency anemia. 


\section{Progestin-only Injectables}

Who can't Use

Category3-4 of WHO medical eligibility criteria; women who:

- Are breast feeding a baby less than 6 weeks old.

- Have severe cirrhosis of the liver or liver tumor.

- Have high blood pressure, 160/100 mmHg or higher.

- Have had diabetes for more than 20 years, with complications. 


\section{Progestin-only Injectables}

Who can't Use (cont.)

- Have had a stroke, blood clot in their legs or lungs, heart attack, or other serious heart problems.

- Have vaginal bleeding that is unusual for them.

- Have or have had breast cancer.

- Have several conditions that could increase their chances of heart disease (coronary artery disease) or stroke such as diabetes or high blood pressure. 


\section{Progestin-only Injectables}

When to Start

- Having menstrual cycles:

- If she is starting within 7 days after the start of her monthly bleeding, no need for a backup method.

- If it is more than 7 days after the start of her monthly bleeding, she can start injectable any time it is reasonably certain she is not pregnant but she will need a backup method for the first 7 days after the injection. 


\section{Progestin-only Injectables}

When to Start (cont.)

- Fully or nearly fully breastfeeding (6 weeks 6 months after giving birth):

- If her monthly bleeding has not returned, and she is fully lactating she can start injectable any time between 6 weeks and 6 months with no need for a backup method.

- If her monthly bleeding has returned she can start injectable as advised for women having menstrual cycles. 


\section{Progestin-only Injectables}

When to Start (cont.)

- Fully or nearly fully breastfeeding (More than

6 months after giving birth):

- If her monthly bleeding has not returned, and fully lactating she can start injectable any time if it is reasonably certain she is not pregnant but she will need a backup method for the first 7 days after the injection.

- If her monthly bleeding has returned she can start injectable as advised for women having menstrual cycles. 


\section{Progestin-only Injectables}

When to Start (cont.)

- Non breastfeeding women:

- Less than 4 weeks after giving birth: she start injectable any time no need for a backup method.

- More than 4 weeks after giving birth: if her monthly bleeding has not returned, she can start injectable any time if it is reasonably certain she is not pregnant but she will need a backup method for the first 7 days after taking the injection.

- if her monthly bleeding has returned she can start injectable as advised for women menstruating. 


\section{Progestin-only Injectables}

When to Start (cont.)

- After miscarriage or abortion:

- She can start within 7 days after first or second trimester miscarriage or abortion with no need for a backup method.

- If it is more than 7 days after first or second trimester miscarriage or abortion she can start injectable if it is reasonably certain she is not pregnant, but she will need a backup method for the first 7 days after taking the injection.

- Switching from a hormonal method:

- She may start immediately if she has been using the method consistently and correctly. 


\section{Progestin-only Injectables}

Managing Problems

\begin{tabular}{|c|c|}
\hline Problem & Action taken \\
\hline No monthly bleeding : & $\begin{array}{l}\text { - Reassure client. } \\
\text { - Consider switching to monthly injectable. }\end{array}$ \\
\hline Irregular bleeding: & $\begin{array}{l}\text { Reassure client. } \\
500 \mathrm{mg} \text { Mefenamic acid twice after meals } \\
\text { for } 5 \text { days or } 40 \mathrm{mg} \text { Valedecoxib daily for } 5 \\
\text { days. } \\
\text { If bleeding continues consider other } \\
\text { underlying conditions not related to method } \\
\text { use. }\end{array}$ \\
\hline
\end{tabular}




\section{Progestin-only Injectables}

Managing Problems (cont.)

Problem

Heavy or prolonged bleeding:

\section{Action taken}

- She can try (one at a time) beginning when heavy bleeding starts:

- $500 \mathrm{mg}$ of Mefenamic acid twice daily for 5 days.

- $40 \mathrm{mg}$ of Valdecoxib daily for 5 days.

- 50 ug Ethinyl estradiol daily for 21 days.

- Help woman to choose another method.

- Iron tablets.

- Consider underlying conditions unrelated to method use 


\section{Managing Late Injections}

- If the client is less than 4 weeks late for a repeat injection of DMPA, she can receive her next injection. No need for tests, evaluation, or a backup method.

- A client who is more than 4 weeks late for DMPA, can receive her next injection if it is reasonably certain she is not pregnant. She will need a backup method for the first 7 days. 


\section{Emergency Contraceptive Pills (ECPs)}

- What are emergency contraceptive pills?

- A method to prevent unwanted pregnancy anytime up to 5 days after unprotected intercourse.

- It does not protect against sexually transmitted infections. 


\section{Emergency Contraceptive Pills (cont.)}

Emergency contraception can be provided using one of two methods:

- Emergency contraceptive pills (ECPs)

- Use within 5 days.

- Pills contain a progestin only, or a progestin and an estrogen , previously called " morning after" pills or postcoital contraceptives.

- Intra-uterine devices (IUDs)

- Insert within 5 days and continue use as long term method. 


\section{Emergency Contraceptive Pills (cont.)}

- Mechanism of action:

- Work by preventing or delaying ovulation.

- Pills that can be used as emergency contraceptive pills:

- A special ECP product with levonorgestrel only, or estrogen and levonorgestrel combined.

- Brands available in the Market:

- Contraplan 


\section{Emergency Contraceptive Pills}

Situations to Use

- Voluntary sexual intercourse without contraceptives.

- Sex was forced (rape) or coerced.

- Contraceptive mistakes, such as:

- Condom was used incorrectly, slipped, or broken.

- Couple incorrectly used a fertility awareness method.

- Man failed to withdraw, before ejaculation.

- Failure to take COCs for 3 consecutive days or POPs more than 3hours especially if not lactating

- IUD has come out of place.

- Woman is more than 4 weeks late for her repeat injection of DMPA or more than 7 days late for her repeat monthly injection. 


\section{Emergency Contraceptive Pills}

When to Take

- The sooner ECPs are taken the better they act to prevent pregnancy.

- Can prevent pregnancy when taken any time up to 5 days after unprotected sex. 


\section{Emergency Contraceptive Pills}

\section{Effectiveness}

- If 100 women each had unprotected sex once during the second or third weeks of menstrual cycle (ovulation period) without using contraception 8 can become pregnant.

- If 100 women used progestin only ECPs, 1 from 8 will become pregnant which means that 7 will be protected.

- If 100 women used estrogen and progestin (combined) ECPs, 2 from 8 will become pregnant which means that 6 will be protected.

- Progestin only ECPs are more effective than combined pills as ECPs. 


\section{Emergency Contraceptive Pills}

Side Effects

- Changes in bleeding patterns:

- Slight irregular bleeding for 1-2 days after taking ECPs, or

- monthly bleeding that starts earlier or later than

- expected in the week after taking ECPs.

- Headaches, dizziness, abdominal pain, fatigue, vomiting, breast tenderness and nausea. 


\section{Emergency Contraceptive Pills}

\section{Dosage}

- Levonorgestrel only: $1.5 \mathrm{mg}$ in a single dose.

- If she is using a 2-dose regimen, tell her to take the next dose within 12 hours each contain $0.75 \mathrm{mg}$ levonorgestrel

- Combined ( Ethinyl estradiol and Levonorgestrel, low dose or standard dose COC: two doses each dose should contain at least :

- 100 microgram (0.1 mg) Ethinyl estradiol.

- 500 microgram (0.5 mg) Levonorgestrel. 


\section{أهم الشائعات المتعلقة بحبوب تنظيم الأسرة}

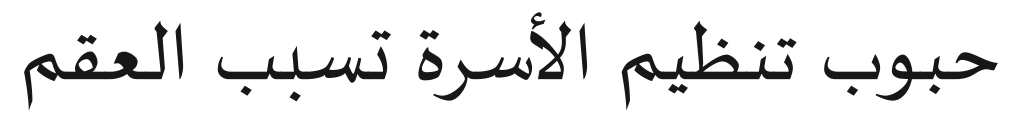

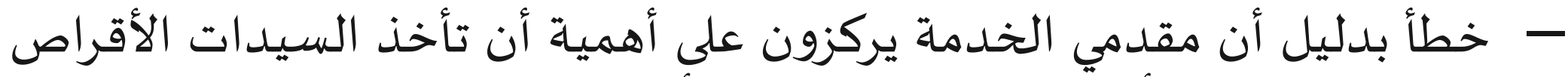

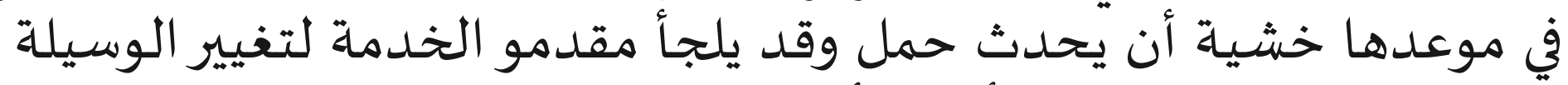
للسيدات اللاتي لا يتذكرن أخذ الأقراص في موعدها.

حبوب تنظيم الأسرة تسبب الأورام

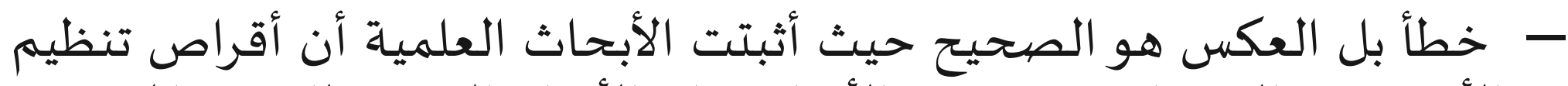
الأسرة تقي السيدات من بعض الأورام مثل: الأورام الخبيثة للرحم والمبيضين.

حبوب تنظيم الأسرة تتسبب في ولادة أطفال مشوهين


لأقراص تنظيم الأسرة بالخطأ بينما هي حامل. 


\section{أهم الشائعات المتعلقة بحقن تنظيم الأسرة}

\section{حقن تنظيم الأسرة تسبب العقم}

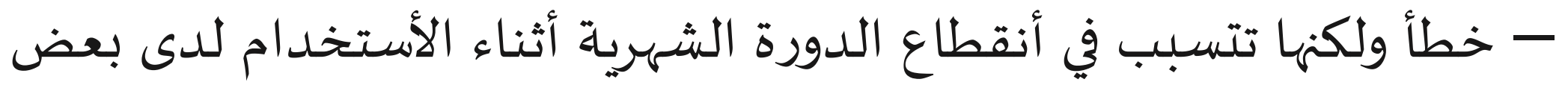

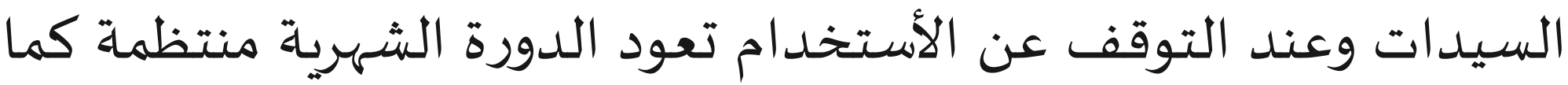

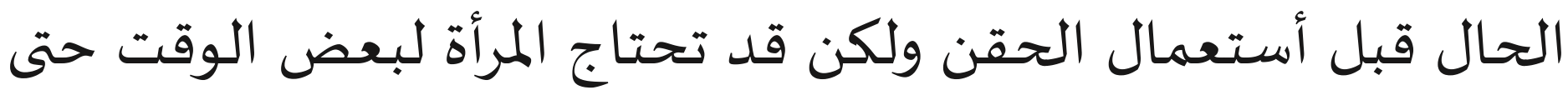

$$
\text { حقن تنظود دورتها الشهرية للأنتظام (أقل من } 9 \text { شهور). }
$$

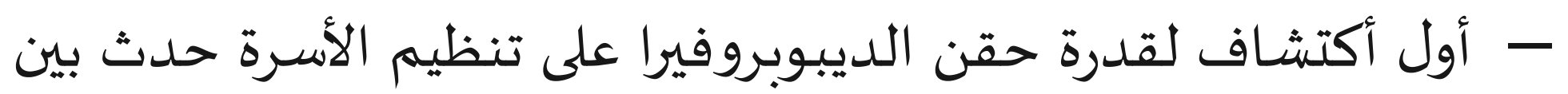

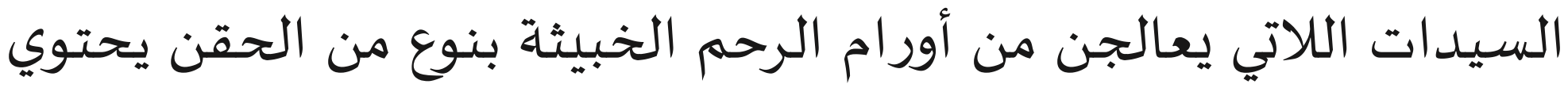

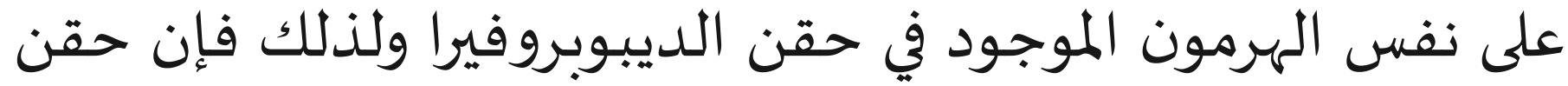
الديبوبروفيرا تقي السيدات من أورام الرحم الخبونيثة. 
أهم الشائعات المتعلقة بكبسولات تنظيم الأسرة والوسائل الهرمونية

\section{تسبب الوسائل الهرمونية زيادة في الوزن}

- قد تسبب الوسائل الهرمونية بعض التغيرات الطفيفة في الوزن سواء

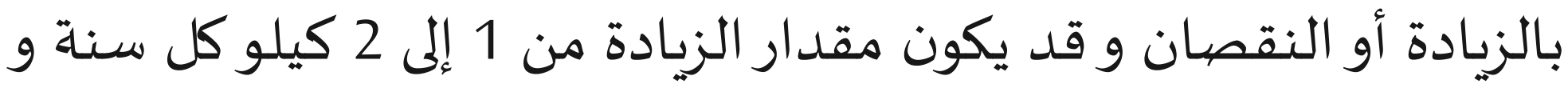
يجب على السيدة مراجعة عاداتها الغذائية أثناء استخدام الحقاء الحقن. الكبسولة تسيح عند تعرض السيدة لحرارة الفرن - تغرس الكبسولة تحت الجلد و لذا فإنه من غير الممكن وصول حرارة

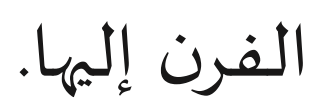




\section{DAY TWO}


SESSION 1 


\section{Objectives}

- By the end of the session the participant will be able to:

- Discuss CuT 380A and Mirena with respect to effectiveness, indications, WHO eligibility criteria, side effects and management of selected problems.

- Discuss common rumors about IUDs and how to respond to them. 


\section{CuT - 380 A Intrauterine Device (IUD)}

- What is an IUD ? A small, flexible plastic frame with copper sleeves or wire around it

- Works primarily by causing chemical changes that affect sperm and ovum before they meet (interferes with fertilization). 


\section{IUD}

\section{Effectiveness}

- It is one of the most effective long acting reversible methods ( LARCs).

- Effective for 12 years and immediately reversible.

- Less than 1 pregnancy occurs per 100 women using IUD in the first year.

- Over 10 years of use : about 2 pregnancies occur per 100 women. 


\section{IUD}

Myths

- It is important for the provider to correct the following myths about IUD :

- Does not move to other parts in the body (heart, brain....).

- Does not cause discomfort during sex.

- Substantially reduces the risk of an ectopic pregnancy. 


\section{IUD}

Advantages

- Very effective, Long acting.

- Has no future costs after insertion (inexpensive).

- Does not require women to do much follow up after insertion.

- Preferred by many women. 


\section{IUD}

Who can Use

- Women who have or have no children.

- Women of any age.

- Women who are breastfeeding. 


\section{IUD}

\section{Side Effects}

- Changes in bleeding pattern ,especially in the first 36 months:

- Prolonged or heavy periods.

- Irregular bleeding.

- Cramps/pain during periods.

- May contribute to anemia (uncommon).

- PID may rarely occur if the woman has STIs (Chlamydia or Gonorrhea) at the time of insertion.

- Miscarriage, preterm birth or infection in rare cases of pregnancy with IUD in place.

- Perforation is a very rare complication and usually heals without treatment. 
When to Start

- A woman can start the IUD at any time if it is reasonably certain she is not pregnant (pregnancy checklist).

- Switching from another method: immediately if she has been using the method consistently and correctly.

- Shortly after childbirth: within 48 , If it is more than 48 hours after giving birth, delay until 4 weeks or more. 
When to Use (cont.)

- After miscarriage or abortion:

- Immediately if within 12 days in case of 1 st or 2 nd trimester abortion with no signs of infection.

- After 12 days, can be inserted at any time as long as it is reasonably certain she is not pregnant.

- IUD insertion after 2nd trimester miscarriage or abortion requires specific training. If not specifically trained, it should be delayed to 4 weeks or more. 


\section{IUD}

\section{When Not to Use}

- Between 48 hours and 4 weeks after childbirth.

- Unusual (undiagnosed) vaginal bleeding.

- Certain gynecological problems such as genital cancer or TB.

- Noncancerous (benign) gestational trophoblast disease.

- AIDS unless she is clinically well and on ARV therapy.

- High risk for Chlamydia or gonorrhea.

- Pregnancy. 


\section{Screening Questions for Pelvic Examination Before IUD Insertion}

- Ask the following 7 questions, if the answer is yes to any of them, do not insert an IUD :

- Is there any type of ulcer on the vulva, vagina or cervix?

- Does the client feel pain in the lower abdomen when you move the uterus?

- Is there adnexal tenderness? 


\section{Screening Questions for Pelvic Examination Before IUD Insertion (cont.)}

- Is there purulent cervical discharge ?

- Does the cervix bleed easily on touch ?

- Is there anatomical abnormality of the uterine cavity that will prevent correct IUD insertion?

- Were you unable to determine the size and or position of the uterus? 


\section{IUD}

Managing Some Problems

- Husband can feel strings: explain that this happens sometimes if threads are cut too short.

- Suspected uterine perforation:

- If suspected during insertion or sounding stop procedure and remove IUD (if inserted), observe in the clinic for few hours if stable, no signs of hemorrhage, send client home, ask her to avoid sex for 2 weeks.

- If there are signs of Hemorrhage, refer to a higher level.

- If perforation is suspected 6 weeks after insertion or later and causing symptoms refer client for evaluation. 
Managing Some Problems (cont.)

- Partial expulsion: remove.

- Missing strings: (possibilities are pregnancy, perforation, or expulsion)

- Ask client about last time she felt threads.

- If IUD came out, when was her last period, then check for symptoms of pregnancy, search for strings in the CX with forceps and exclude pregnancy. 


\section{IUD}

Managing Some Problems (cont.)

- Spotting:

- Happens for a few days before onset of menstruation:

- Reassure the client that spotting is common.

- If intermenstrual: remind the client of the AlAzhar fatwa that this is "Istehada" and should not prevent her from performing religious duties e.g., praying and fasting. 
Managing Some Problems (cont.)

- Heavy or prolonged bleeding (twice as much as usual or longer than 8 days)

- Reassure her that many women using IUDs experience heavy or prolonged bleeding. It is generally not harmful and usually becomes less or stops after the first several months of use, advise her to eat foods containing iron.

- She can try Tranexamic acid (1500 mg ) 3 times daily for 3 days then(1000 $\mathrm{mg}$ ) once daily for 2 days.

- NSAIDs such as Ibuprofen (400 mg) 2 times daily after meals for 5 days. 
Managing Some Problems (cont.)

- If heavy or prolonged bleeding continues or starts after several months of normal bleeding, or you suspect that something may be wrong for other reasons, consider underlying conditions unrelated to method use.

- If severe and persists, remove the IUD.

- If persists after removal of IUD, refer to hospital for evaluation. 


\section{Suspected Pregnancy with IUD}

- Exclude ectopic pregnancy, explain the risk of preterm delivery or miscarriage including septic miscarriage during 1st or 2nd trimester (life threatening).

- If the client wants to keep pregnancy, advise her it is best to remove IUD. Gently remove IUD or refer client for removal:

- If strings seen pull out.

- If strings not seen do ultrasound.

- If client chooses to keep IUD, her pregnancy must be followed closely, advise her to come immediately if she develops signs of miscarriage or septic miscarriage.

- Ultrasound examination is recommended when strings are not seen and IUD cannot be safely retrieved. 


\section{Mirena}

- What is Mirena?

- Levonorgestrel -releasing Intra Uterine System.

- Mirena contains 52 mg of Levonorgestrel (LNG). Initially, $L N G$ is released at a rate of $20 \mathrm{mcg} /$ day.

This rate decreases progressively to half value

\section{VMirena}




\section{Mirena}

- Mechanism of action: Mirena IUD releases progesterone that thickens the cervical mucus, thins the lining of the endometrium and partially prevents ovulation.

- Effectiveness:

- It is over $99 \%$ effective .

- Mirena is effective for up to 5 years. 


\section{Mirena}

- Treats heavy periods.

- Bleeding and spotting may increase in the first 3-6 months and remain irregular.

- Periods overtime usually become shorter, irregular or may stop.

- Mirena does not protect against STIs or HIV.

- May be expensive. 
- Mirena must be removed by the end of the fifth year and can be replaced at the time of removal with a new Mirena if continued contraception is required.

- Ectopic pregnancy : evaluate women for ectopic pregnancy if they become pregnant with Mirena because the likelihood of pregnancy being ectopic is increased up to half of pregnancies. 




\section{اللولب بيسرح داخل البطن ويصل للقلب:}

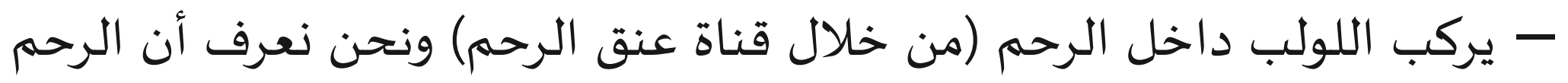

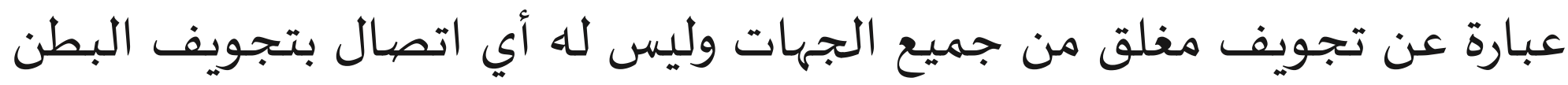

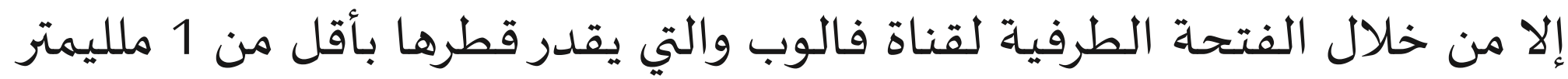

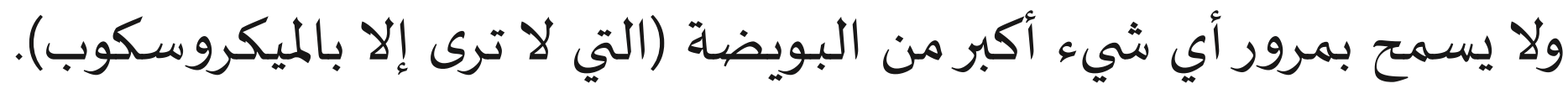

اللولب بيدخل دماغ الجنين لو حصل حمل:

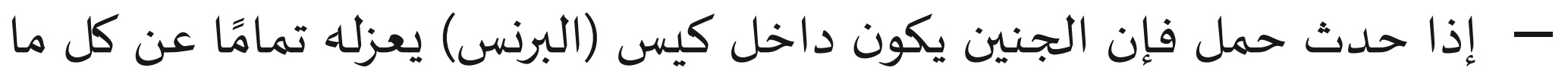

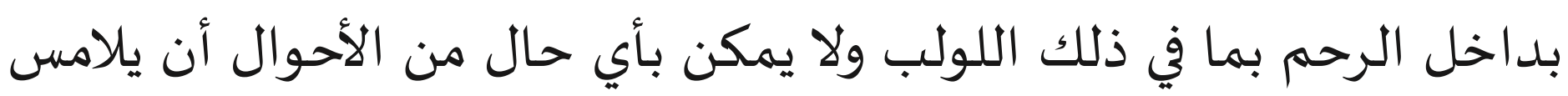

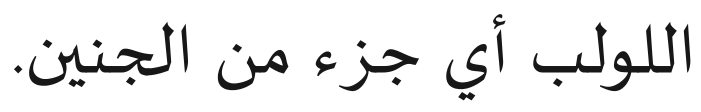




\section{أهم الشائعات المتعلقة باللولب (تابع)}

\section{تحتاج السيدات لفترة راحة بعد إزالة اللوالب:}

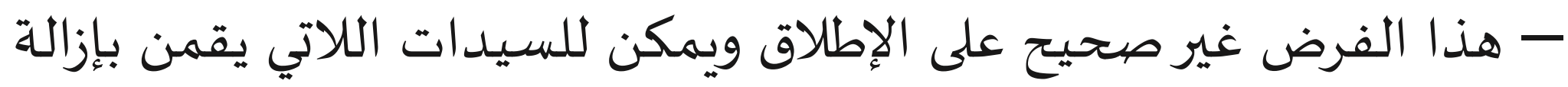

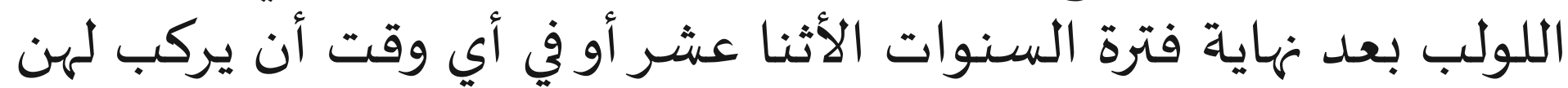

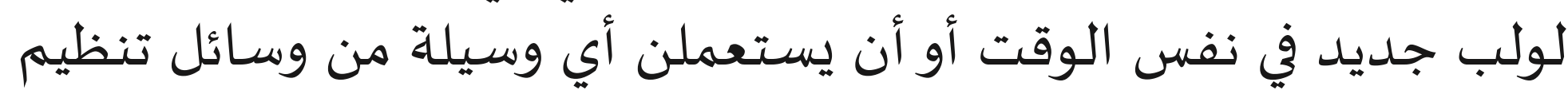
الأسرة إذا رغبن في تغيير الوسيلة.

اللولب ممكن يسبب ثقب في الرحم عند تركيباء:



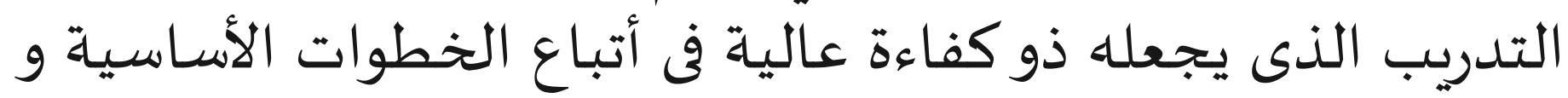
الصحيحة في تركيب اللولب. 
SESSION 2 


\section{Objectives}

- By the end of the session the participant will be able to:

- Explain steps of IUD insertion and removal.

- Demonstrate competence in IUD insertion and removal on pelvic models using the clinical skills checklist.

- Explain follow-up care of IUD. 


\section{Basic Principles for IUD Insertion}

- Before any steps alert the lady that the process might cause pain.

- Gentle techniques minimize discomfort.

- Use No-touch technique.

- The cervix and vagina should be thoroughly painted with antiseptic such as lodophor (Betadine ${ }^{\circledR}$ ) 


\section{Basic Principles for IUD Insertion (cont.)}

- The uterine cavity should always be sounded to confirm the position of the uterus and the depth of the cavity.

- Set the depth gauge on the IUD to the level on the uterine sound.

- Insert the IUD high in the fundus of the uterus by withdrawal technique, as there is less risk of expulsion. 


\section{Procedure for Inserting IUD}

- Wash hands and put on sterile or high level disinfected gloves

- Insert the speculum. Thoroughly clean the cervix with an antiseptic solution

- Apply sterile Tenaculum at the 10 o'clock and 2 o'clock positions on the cervix.

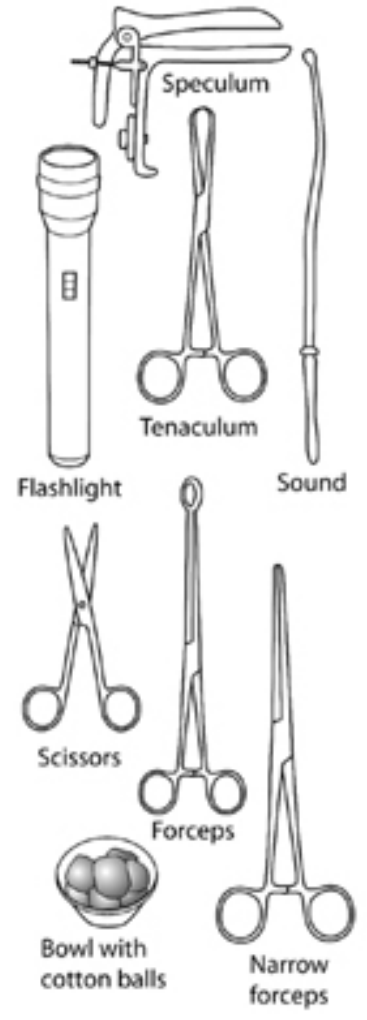

Needed Instruments 


\section{Procedure for Inserting IUD (cont.)}

- Uterine Sounding:

- Pick up the handle of the sound, do not touch the tip.

- Turn the sound so that it is in the same direction as the uterus.

- Gently pass the sterile tip of the uterine sound into the cervical canal.

- Keep a firm grip with the Tenaculum. 


\section{Procedure for Inserting IUD (cont.)}

- Carefully and gently, insert the uterine sound in the direction of the uterus while gently pulling steadily downwards and outward on the Tenaculum

- Do not attempt to dilate the cervix

- If client begins to show symptoms of fainting or pallor with slow heart rate STOP 


\section{Procedure for Inserting IUD (cont.)}

- Slowly withdraw the sound, it will be wet and darker where it was in the uterus.

- Place the sound next to the IUD and set the blue depth gauge at the depth of the uterus.

- Determine the length of the uterus by noting the mucus and or blood on the sound.

- The average uterus will sound to a depth of 6 to 8 centimeters. 


\section{Instructions for Loading the CUT 380A in the Sterile Package}

- Non-touch Loading of the CuT 380A

- Make sure that the vertical stem of the T is fully inside the inserter tube

- Place the package on a clean, hard, flat surface with the clear plastic side up.

- Partially open the end of the package farthest from the IUD.

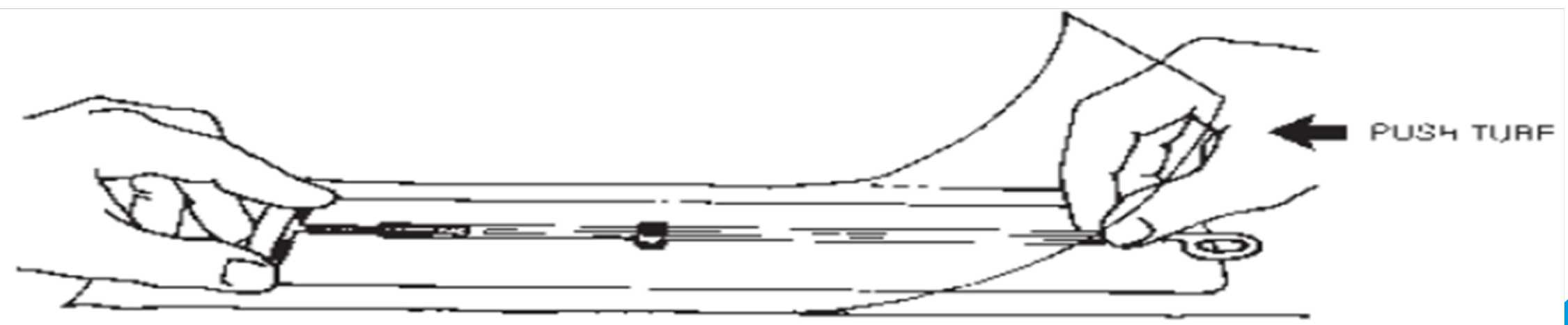




\section{Instructions for Loading the CUT 380A in the Sterile Package}

- Pick up the package, holding the open end up towards the ceiling so that the contents do not fall out.

- Release the white backing flap so that it is flat, and place the package on a flat surface with the clear plastic side up.

- Through the clear plastic cover, place your thumb and index finger over the ends of the horizontal arms of the T and hold the $\mathrm{T}$ in place.

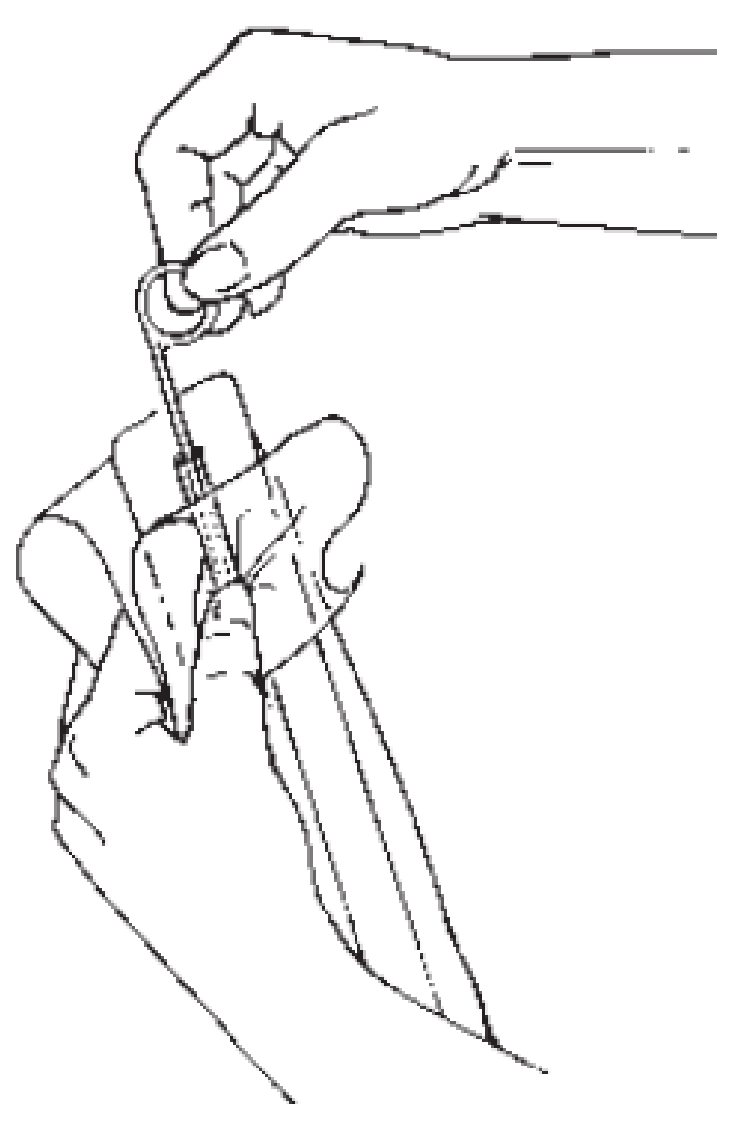




\section{Instructions for Loading the CUT 380A in the}

\section{Sterile Package}

- Continue bending the arms of the T by

bringing the thumb and index finger together.

- When the arms have folded enough to touch the sides of the inserter tube, pull the inserter tube out from under the tips of the arms.

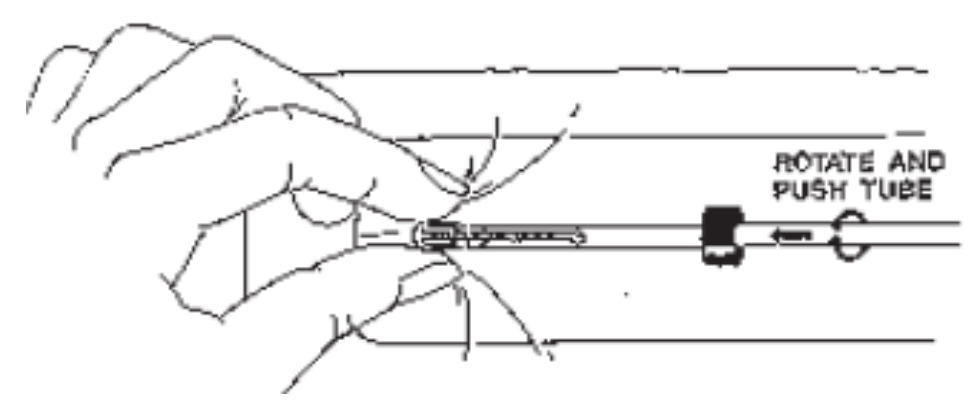




\section{Instructions for Loading the CUT 380A in the}

Sterile Package (cont.)

- Push and rotate the inserter tube onto the tips of the arms so that the arms become trapped inside the inserter tube

- Insert the folded arms into the tube only as far as necessary to ensure retention of the arms.

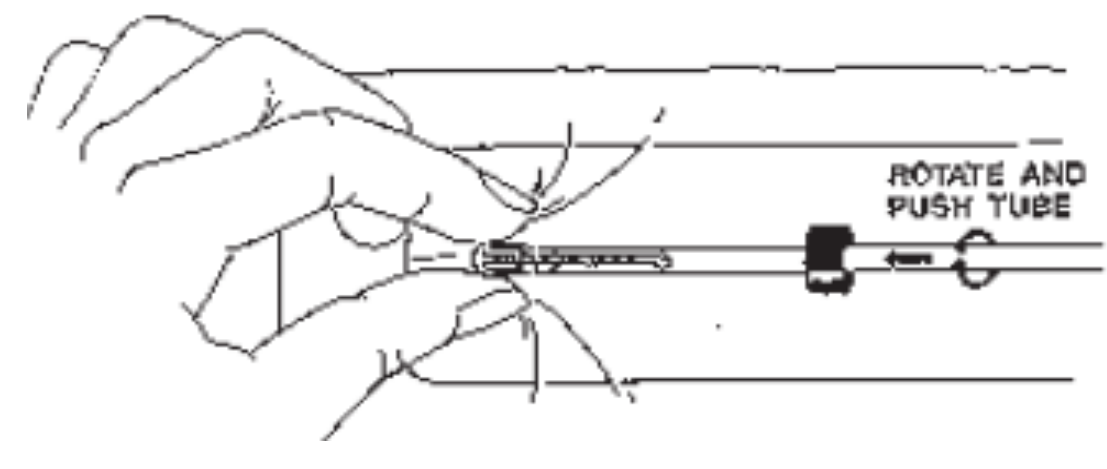




\section{Instructions for Loading the CUT 380A in the Sterile Package (cont.)}

- The blue depth gauge on the inserter tube is used to mark the depth of the uterus

- Holding the blue depth gauge in place through the clear plastic wrapper, grasp the inserter tube at the open end of the package with your free hand.

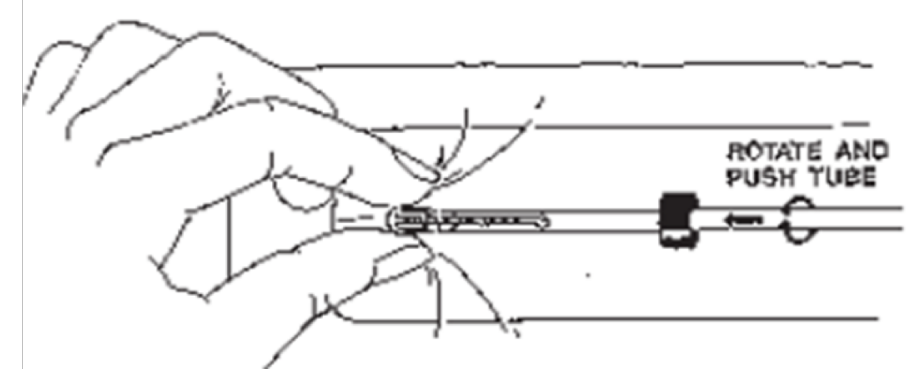




\section{Instructions for Loading the CUT 380A in the}

\section{Sterile Package (cont.)}

- Pull the inserter tube gently until the distance between the top of the folded T and the edge of the blue depth gauge closest to the $T$ is equal to the depth of the uterus as measured on the uterine sound.

- Rotate the inserter tube so that the long axis of the blue depth gauge is on the same horizontal plane as the arms of the $\mathrm{T}$. 


\section{Instructions for Loading the CUT 380A in the Sterile Package (cont.)}

- The IUD is now ready to be placed in the woman's uterus. Carefully peel the clear plastic cover of the package away from the white packing.

- Lift the loaded inserter, keeping it horizontal, so that the $(T)$ doesn't fall out.

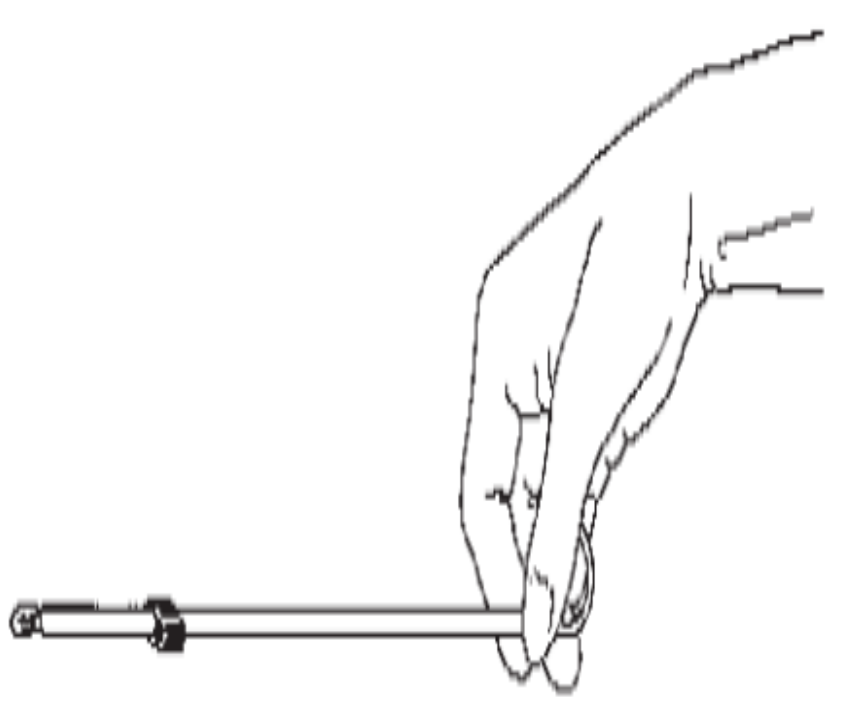

- Be careful not to push the white rod towards the $T$ until you are ready to release the $T$ in the fundus.

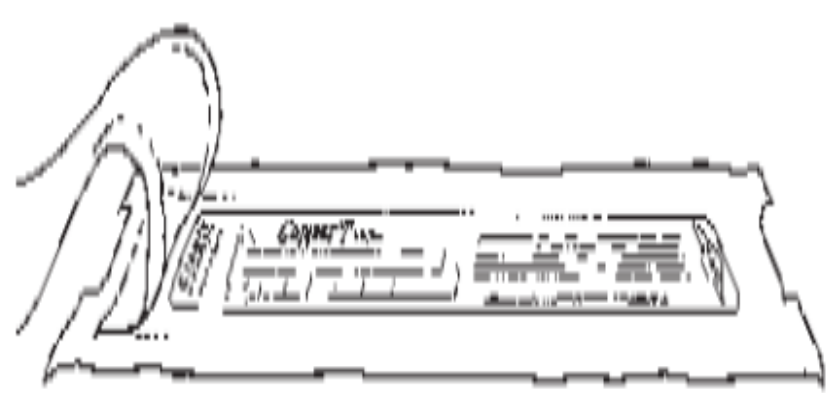




\section{Inserting the Loaded CUT 380A IUD}

- Grasp the Tenaculum and pull firmly to pull the uterine cavity and cervical canal in line with the vaginal canal.

- Gently place the loaded inserter tube through the cervical canal.

- Keep the blue depth gauge in a horizontal position.

- Advance the loaded IUD until the blue depth gauge touches the cervix or resistance of the uterine fundus is felt.

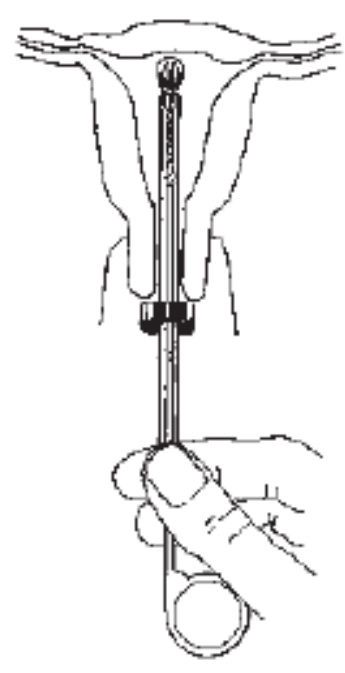

- Keep the blue depth gauge in a horizontal position. 


\section{Inserting the Loaded CUT 380A IUD (cont.)}

- Hold the Tenaculum and the white rod in place in one hand.

- With your other hand, withdraw (pull toward you) the inserter tube until it touches the thumb grip of the white rod.

- This will release the arms of the TCu 380A high in the uterine fundus.






\section{Inserting the Loaded CUT 380A IUD}

- Once the arms have been released, again very gently and carefully, push the inserter tube upward, toward the top of the uterus, until you feel a slight resistance.

- This step ensures that the arms of the T are as high as possible in the uterus.

- Hold the inserter tube still while removing the white

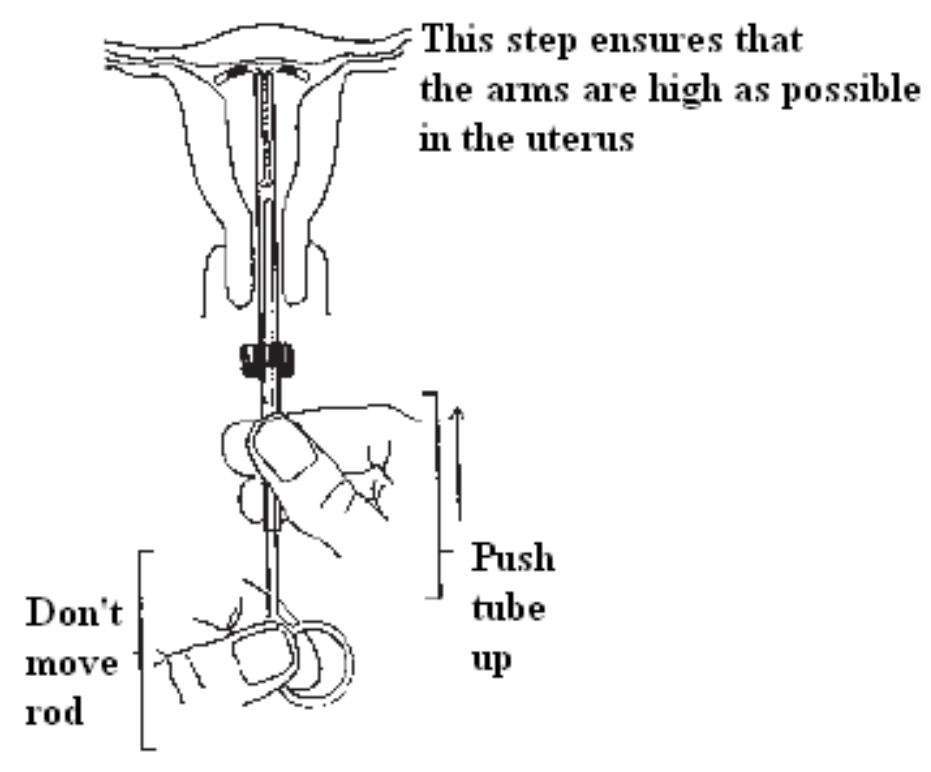
rod. 


\section{Inserting the Loaded CUT 380A IUD}

- Gently and slowly withdraw the inserter tube from the cervical canal.

- The strings should be visible protruding from the uterus.

- Cut the strings so that they protrude only three to four centimeters into the vagina.

- Remove the tenaculum.

- If the cervix is bleeding from the tenaculum site, press a swab to the site, using clean forceps, until the bleeding stops.

- Gently remove the speculum and put all of the instruments used in liquid soap and water 


\section{IUD Follow-Up Care}

- Routine follow-up visits:

- First follow-up three to six weeks after IUD insertion

- The client can return for a visit to have the IUD removed when it has been in place for the recommended number of years, (12 years for the T Cu 380A) or when client wishes to have it removed for any reason.

- Visit if she has questions, concerns, or any of the following signs/symptoms she thinks may be caused by the IUD. 


\section{IUD Follow-Up Care (Cont)}

- Any time she has:

- Fever, chills (a possible sign of infection).

- Increasing or severe abdominal pain.

- Pain during intercourse.

- Purulent or foul smelling discharge.

- If she thinks the IUD might be out of place (strings become shorter, longer, or missing).

- If she thinks she might be pregnant. 
SESSION 3 


\section{Objectives}

- By the end of the session participants will be able to:

- Discuss effectiveness, side effects, health benefits and risks of barrier and local methods.

- Explain the natural methods : LAM, fertility awareness method and withdrawal. 


\section{Barrier Methods}

- Barrier method means there is a physical device to prevent sperm from entering the woman's reproductive tract.

- Examples of barrier birth control methods include: Female and male Condoms,

Diaphragms, ..........

- Effective at preventing pregnancy and some STIs when used

- Consistently and correctly.

- Using a spermicide with a barrier method gives you the best possible barrier method protection. 


\section{Advantages of Barrier Methods}

- Easy to initiate or discontinue.

- Immediate return to fertility.

- Are only used at the time of sexual intercourse.

- Are safe for a woman to use while she is breastfeeding.

- Do not affect other health conditions, such as high blood pressure or diabetes.

- Are less expensive than hormonal methods, and some are available without a prescription.

- Condoms also are the best method for reducing the risk of sexually transmitted infections, including HIV. 


\section{Male Condoms}

- The condom forms a barrier that prevents sperms from reaching the cervix during sex.

- Most condoms are made of thin latex rubber, some are coated with a lubricant and/or spermicide.

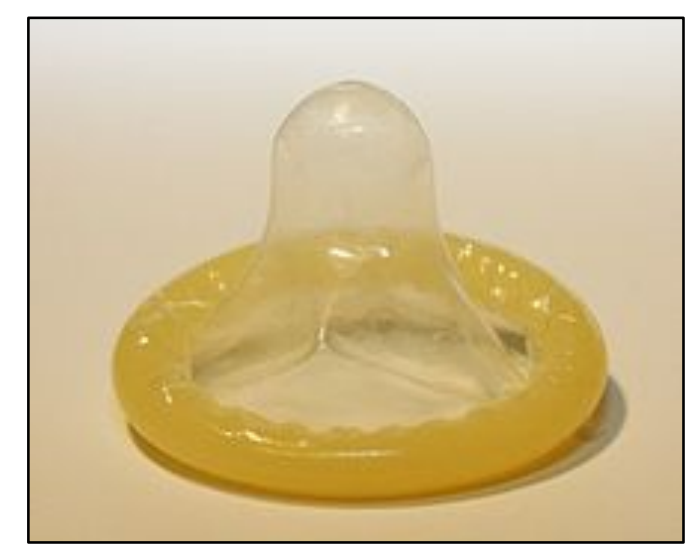




\section{Effectiveness of Male Condoms}

- As commonly used about 15 pregnancies per 100 women whose partners use male condom over the first year (85\%).

- Return of fertility after use of male condom is stopped: no delay. 


\section{Advantages of Male Condoms}

- Protect against risks of pregnancy.

- It protects from acquiring or transmitting STIs including HIV.

- Can be used as a temporary or backup method.

- Can be used without seeing a health provider.

- Increase male participation in family planning. 


\section{Disadvantages and Side Effects of Male Condoms}

- Disadvantages:

- May decrease sensation, making sex less enjoyable for either partner.

- May cause an allergic reaction to latex rubber.

- It might take time to put the condom on the erect penis before the penis touches the woman's genital and hence husband may lose erection.

- Side effects:

- None 


\section{How to Use Male Condoms}

- Use a new male condom for each act of sex.

- Before any vaginal contact, place the condom on the tip of the erect penis, the rolled side should be on the outside.

- Unroll the condom all the way to the base of the erect penis, if the condom does not unroll, it may be on backwards, damaged, or too old.

- Use water or a water - based lubricant on the outside of the condom this helps prevent breaks, do not use creams, oils, or petroleum jelly.

- Immediately after ejaculation, hold the rim of the condom in place, withdraw the penis while it is still erect, and be careful not to spill semen when withdrawing the penis or taking off the condom.

- Store condoms in a dark, cool, dry place if possible. 


\section{Female Condoms}

- What are female condoms?

- The female condom is a sheath made of a transparent latex with flexible rings at both ends, it is the same length as a male condom. The condom forms a barrier that keeps sperms out of the vagina during sex and hence prevents pregnancy. 


\section{Effectiveness of Female Condoms}

- As commonly used about 21 pregnancies per 100 women using FC over the first year.

- Return of fertility after use FC is stopped. 


\section{Advantages of Female Condom}

- Protect against risks of pregnancy.

- It protects from acquiring or transmitting STIs including HIV.

- Can be used as a temporary or backup method.

- Can be used without seeing a health provider.

- Can be used during pregnancy to protect mother and fetus against STIs.

- Controlled by the women. 


\section{Disadvantages and Side Effects of Female Condom}

- Disadvantages:

- May be relatively expensive and hard to find.

- Must not be used if the partner is using a male condom, the friction between the two condoms may cause one or both to break.

- May make noises during intercourse, adding lubricant can help.

- Side effects:

- None 


\section{How to use Female Condom}

- Use a new female condom for each act of sex.

- Insert up to 8 hours before sex, for the best protection insert before the penis comes into contact with the vagina.

- After the man withdraws his penis, hold the outer ring of the condom, twist to seal in fluid, and gently pull it out of the vagina, it is preferred to remove before standing. 


\section{Spermicides}

- What are spermicides?

- Sperm-killing substances inserted deep in the vagina, near the cervix, before sex.

- Available in foaming tablets, melting or foaming suppositories, melting film, jelly, and cream.

- Can be used alone or with a diaphragm or with condoms.

- Work by causing the membrane of sperm cells to break, killing them or slowing their movement, thus keeping sperm from meeting the ovum. 


\section{Effectiveness and Advantages of Spermicides}

- Effectiveness:

- As commonly used about 29 pregnancies per 100 women using spermicides over the first year (71\%).

- Return of fertility after use is stopped: no delay.

- Advantages:

- Spermicides are controlled by the woman, can be used without seeing a health care provider.

- Increase vaginal lubrication \& do not reduce vaginal secretions .

- Have no hormonal side effects. 


\section{Disadvantages and Side Effects of Spermicides}

- Disadvantage:

- Do not protect against STIs.

- Side effects: Some users report the following:

- Irritation in or around the vagina or penis.

- Other possible physical changes as vaginal lesions.

- Urinary tract infection especially when using spermicides 2 or more times a day (uncommon) 


\section{How to Use Spermicides}

- Insert spermicides at least 10 minutes to 1 hour before each intercourse to allow the spermicide to dissolve and spread in the vagina.

- It should be used each act.

- Wait for at least 6 hours after sex before douching. 


\section{Combined Vaginal Ring}

- What is combined vaginal ring?

- A flexible ring placed in the vagina, continuously releases 2 hormones (progestin and an estrogen) like the natural hormones progesterone and estrogen in a woman's body from inside the ring, hormones are absorbed through the wall of the vagina directly into the bloodstream. Also called Nova ring. 


\section{Combined Vaginal Ring (cont.)}

- Mechanism of action:

- Works primarily by preventing the release of eggs from the ovaries (ovulation).

- How to use:

- The ring is kept in place for 3 weeks, then removed for the fourth week, during the fourth week the woman will have her menses, a new ring is inserted at the end of the fourth week. 


\section{Effectiveness of Combined Vaginal Ring}

- Combined vaginal ring is new and research on effectiveness is limited.

- Risk of pregnancy is greatest when a woman is late to start a new ring.

- Return of fertility after ring use is stopped: no delay.

- Long term studies of the vaginal ring are limited, but researches suggest that its advantages and disadvantages are like those of COCs. 


\section{Side Effects of Combined Vaginal Ring}

- Changes in bleeding patterns including :

- lighter bleeding and fewer days of bleeding.

- Irregular bleeding.

- Prolonged bleeding.

- Headaches, irritation, redness, or inflammation of the vagina, white vaginal discharge. 


\section{Combined Patch}

- What is combined patch?

- A small, thin, square of flexible plastic worn on the body, continuously releases 2 hormones (progestin and an estrogen directly through the skin into the bloodstream). Works primarily by preventing the release of eggs from the ovaries (ovulation). 


\section{How to Use Combined Patch}

- A new patch is worn every week for 3 weeks, then no patch for the fourth week, during the fourth week the woman will have her menses.

- Patch is inserted on any part except the breast, change place every time). 


\section{Effectiveness of Combined Patch}

- Combined patch is new and research on effectiveness is limited.

- Risk of pregnancy is greatest when a woman is late to change the patch.

- Pregnancy rates may be slightly higher among women weighing $90 \mathrm{~kg}$ or more.

- Return of fertility after use is stopped: no delay.

- Long term studies of the skin patches are limited, but researches suggest that its advantages and disadvantages are like those of cocs. 


\section{Side Effects of Combined Patch}

- Some users reported the following:

- Skin irritation or rash where the patch is applied.

- Changes in monthly bleeding :

- lighter bleeding and fewer days of bleeding.

- Irregular bleeding.

- Prolonged bleeding.

- No monthly bleeding.

- Headaches, nausea, vomiting, abdominal pain, breast tenderness and pain, flu symptoms/ upper respiratory infection. 


\section{Natural Methods}

- Are considered "natural" because they are not mechanical and not a result of hormone manipulation.

- They're free or low-cost, safe, and effective when you use them the right way. But that's hard to do.

- Examples:

- Lactational Amenorrhea Method (LAM).

- Fertility awareness method.

- Withdrawal method. 


\section{Lactational Amenorrhea Method (LAM)}

- A temporary family planning method based on the natural effect of breastfeeding on fertility.

- LAM requires 3 conditions, all must be met:

- The mother's monthly bleeding has not returned, (amenorrhea afterbirth).

- The baby is fully breastfeed ( he receives no liquid or food, not even water)

- The baby is less than 6 months old. 


\section{Mechanism of Action of LAM: Non-fertile State}

Nipple stimulation by infant suckling

Nerve impulses to the hypothalamus

Release of prolactin and disruption in the release of gonadotrophin releasing hormones (GnRH)

Suppression of FSH and LH

Suppression of Ovulation 


\section{Effectiveness and Advantages of LAM}

- Effectiveness:

- As commonly used about 2 pregnancies per 100 women using LAM in the first 6 months after childbirth ( 98\% ).

- Return of fertility after LAM is stopped: depends on how much the woman continues to breastfeed.

- Advantages:

- Does not interfere with sex.

- No costs and no supplies needed, it is a natural family planning method.

- Provides health benefits for the baby and the mother through exclusive breastfeeding. 


\section{Disadvantages and Side Effects of LAM}

- Disadvantages:

- Does not protect against STIs, must use condoms if at risk of STIs.

- Effectiveness after 6 months postpartum is not certain.

- Full breastfeeding may be inconvenient or difficult for some women.

- Side effects:

- None 


\section{How to Use Lactation Amenorrhea Method}

- Start breastfeeding as soon as possible after the baby is born, if initiated within one hour of birth baby will get the full benefit of colostrums, feed only breast milk day and night.

- Make sure menses has not returned (even spotting).

- Only effective in the first six months post partum. 


\section{Fertility Awareness Method}

- Fertility awareness means that a woman knows when the fertile time of her menstrual cycle starts and ends (the fertile time is when she may become pregnant). Sometimes called periodic abstinence. It depend on observing signs of fertility:

- Cervical secretions: she may feel a little vaginal wetness.

- Basal body temperature (BBT): a woman's resting body temperature goes up slightly after the release of an egg (ovulation), and that is when she could become pregnant. 


\section{Fertility Awareness Method (cont)}

- Mechanism of action:

- The married couple avoids unprotected vaginal sex during these fertile days, or use a condom or other barrier methods during that period.

- It could be used by women whose menstrual cycles are regular and between 26-32 days long.

- The days a woman is more fertile are days 8 to 19 of her menstrual cycle. 


\section{Fertility Awareness Method (Cont)}

- Effectiveness:

- As commonly used in the first year about 25 pregnancies per 100 women using fertility awareness methods ( $75 \%$ effective).

- Advantages:

- There are no costs and no supplies needed.

- It is natural, thus there are no hormones, devices or medical procedures required.

- Promotes male involvement and couple communication.

- No delay in return to fertility. 


\section{Fertility Awareness Method (Cont)}

- Disadvantages:

- Postpartum or breastfeeding women must have 3 regular menstrual cycles before they can use Fertility Awareness Methods.

- Does not protect against sexually transmitted infections(STIs).

- Side effects:

- None 


\section{Withdrawal}

- What is Withdrawal?

- The husband withdraws his penis from his wife's vagina before ejaculation and he ejaculates outside of the vagina. It prevent contact between the sperm and ovum. 


\section{Effectiveness of Withdrawal}

- As commonly used about 27 pregnancies per 100 women whose partner uses withdrawal over the first year(73\%).

- It is one of the least effective methods, yet offers better protection than no method at all.

- Pre-ejaculatory fluid contains sperms and may flow out during intercourse. 


\section{Withdrawal}

\section{Advantages, Disadvantages and Side Effects}

- Advantages:

- May be appropriate for couples who need a temporary method while awaiting the start of another method.

- Requires no supplies and no clinic or pharmacy visit.

- Promotes male involvement and couple communications.

- No delay of fertility after Withdrawal use is stopped.

- Disadvantages:

- Not suitable for men who can not feel when ejaculation is about to occur or ejaculate prematurely.

- Does not protect against sexually transmitted infections(STIs).

- Side effects: None. 
SESSION 4 


\section{Objectives}

- By the end of the session the participant will be able to:

- Discuss best practices of infection control. 




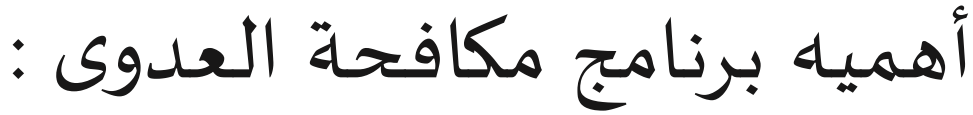

- تعتبر العدوى المكتسبة في المنشآت الصحية مشكلة يعانى منها الكثيرون في

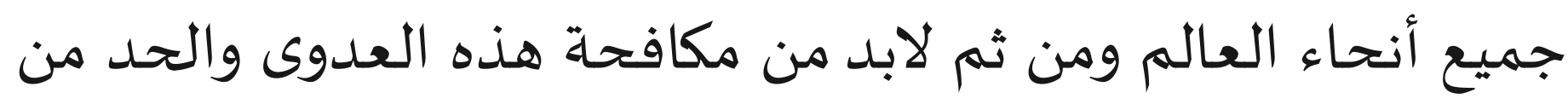

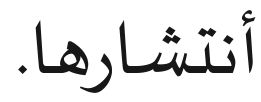

\section{العدوى في المنشآت الصحية :}

- تنتقل العدوى بطريقة مباشرة أو غير مباشرة من القائمين على خدمات الرعاية الصحية إلى المرضى إلا إذا تم الألتزام بالأساليب الصنحيحة الصدياة

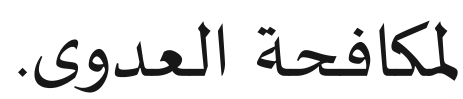




\section{الاحتياطات القياسية لمكافحة العدوى}

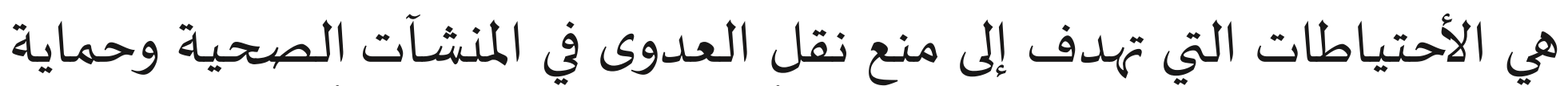

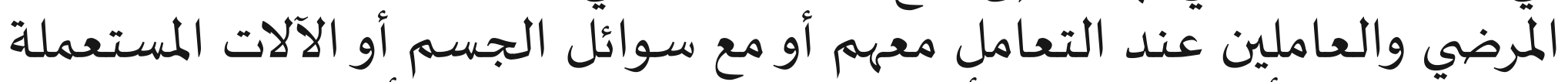

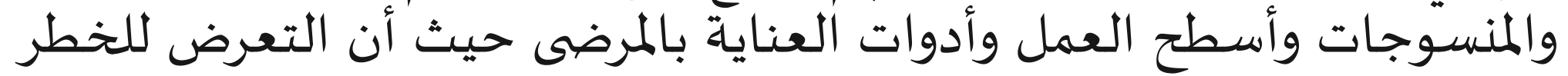
يكمن فى الإجراء نفساه وليس في المريض.



تشمل الأحتياطات القياسيـة الآتى :

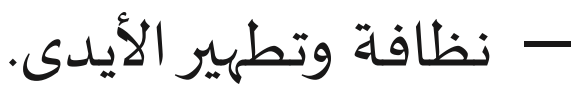
- أدوات الوقاية الشخصية.

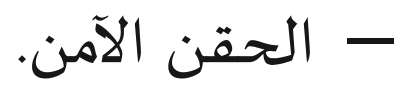

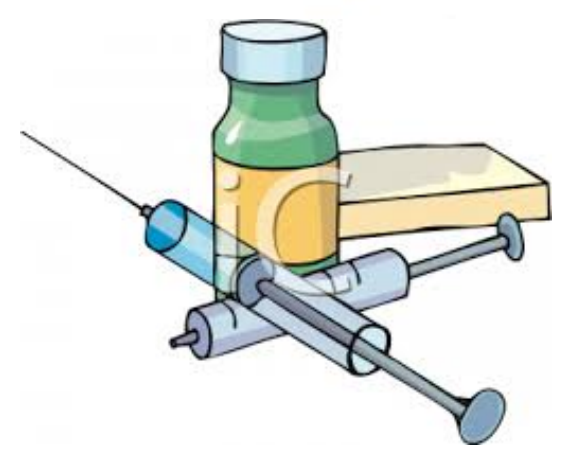

- إعادة معالجة الآلات ( التنظيف والتطهير والتعقيم ) - تنظيف وتطهير البيئة.

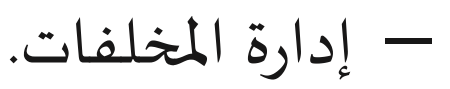




\section{يوجد ثلاث أنواع من غسل الأيدى}

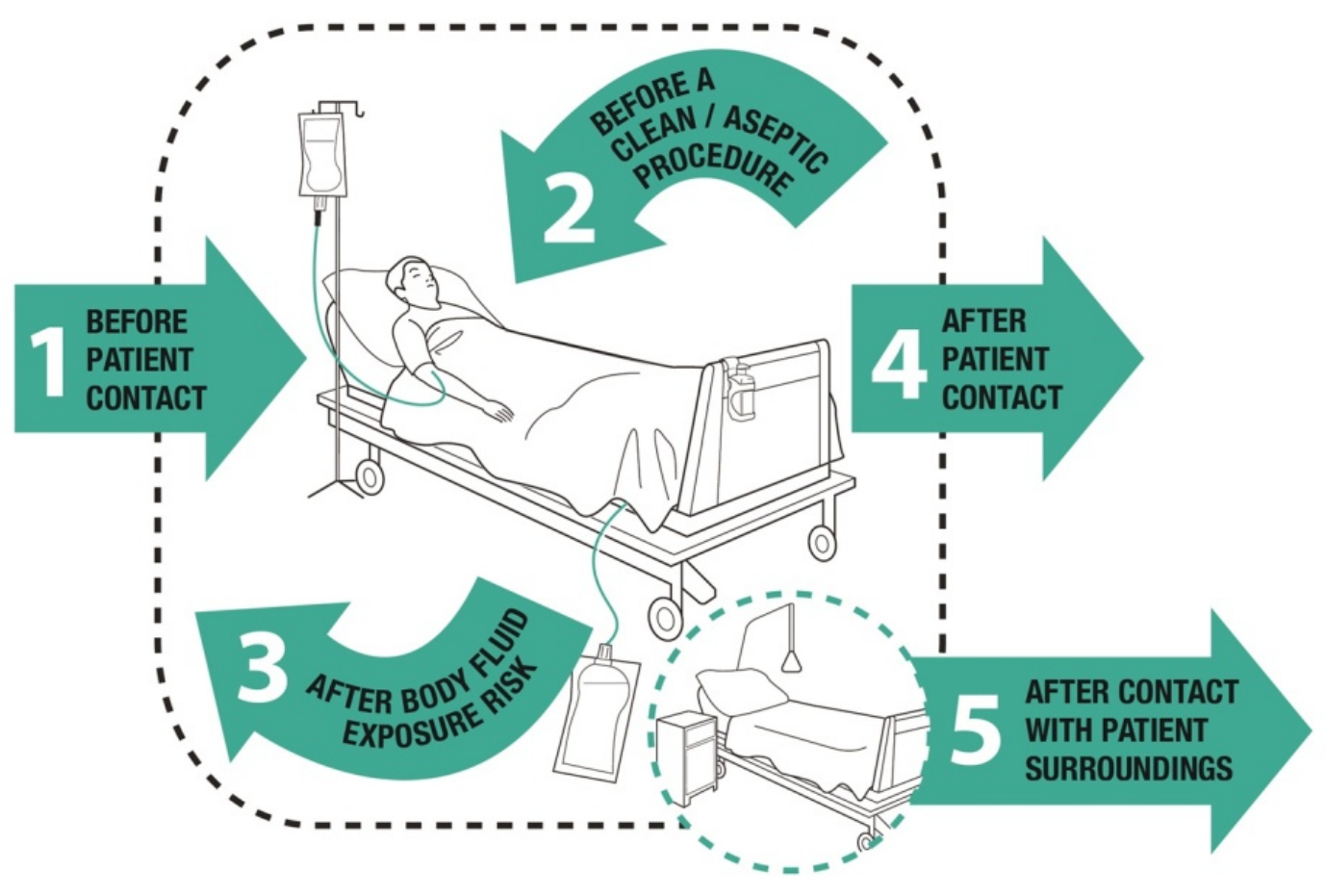

الغسيل الروتيني: ( قبل وبعد العمل - قبل

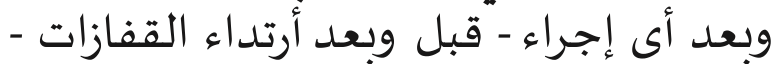
بعد أستعمال الحمام - قبل وبعد تناول أرتل

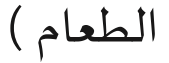

الغسل الصيحي: ( قبل الأجراءت الأختراقية

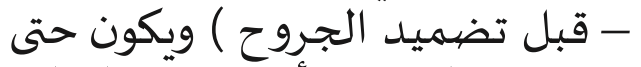
منتصف الساعد بأستخدام المنظف واكت الرغون

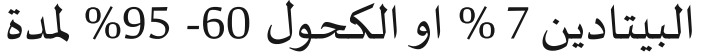
دقيقتين على الأقل ويشطف بادئ باء الماء الجاري.

الغسل الجراحي: (قبل العمليات الجراحية -


العالية ) ويكون حتى أعلى المرفق (الكوع )

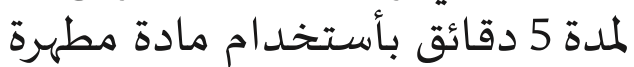

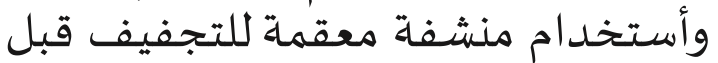

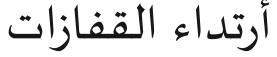




\section{الغسيـل الروتيني للأيدي}



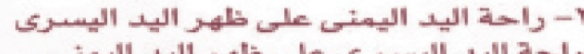

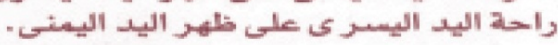

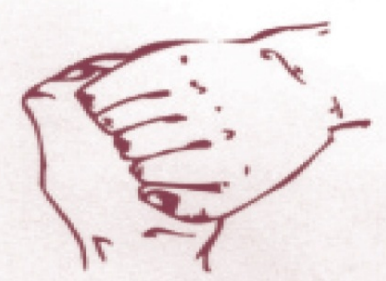

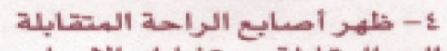

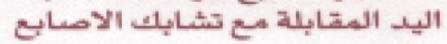

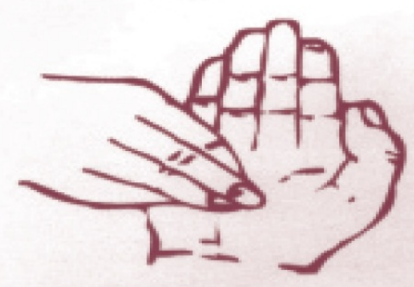

7- الاح-كالت الدائري للخلف

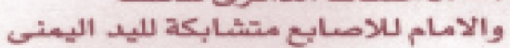

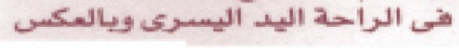

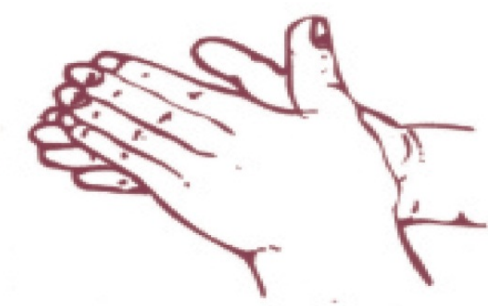

1- راحة اليب الى راحة اليث.

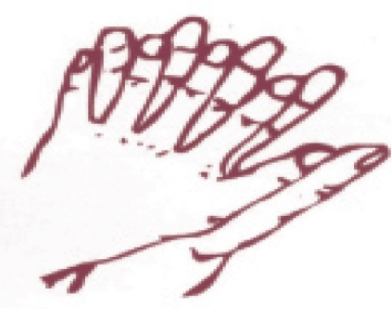

T- أصسابع اليد الصتشايكي

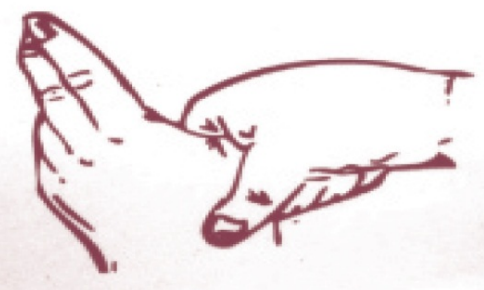

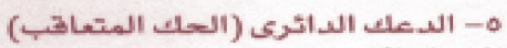

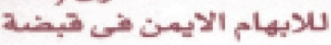
راحة اليث وبالسكين. 


\section{أدوات الوقاية الشخصية في العيادة}

\section{• القفازات ( المعقمة - النظيفة - شديدة التحمل )}



• البالطو ( زى الطبيب )

k34093515 fotosearch.com () 
هو الذي لايتسبب في أذى المتلقي ولا يعرض مقدم الخدمة الى أى الى الحئ مخاطرولاينتج عنه أى نفايات تضر الآخرين أو البيئة. 


\section{العناصر الآساسية للحقن الآمن}

\section{أستخدام أدوات الحقن المعقمة}

توفير كمية كافية من السرنجات لضيمان أستخدام سرنجاة جديدة المعقداة ومعقمة لكل عملية حقن.

التخلص من السرنجات التى تلامس أى سطح غير معقم.

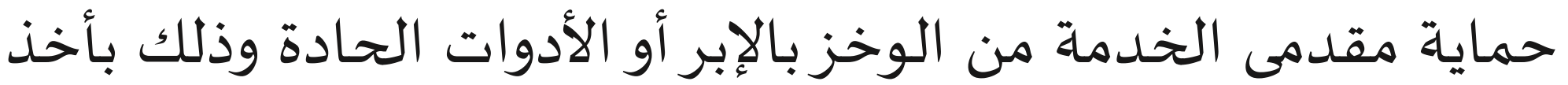

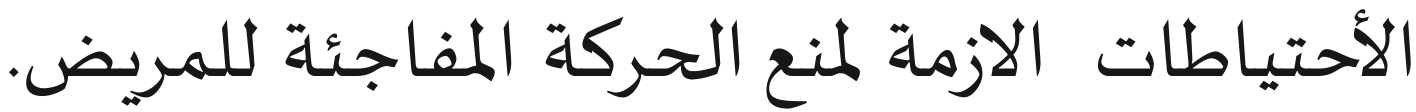

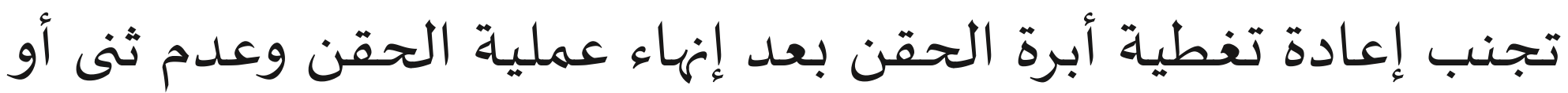
كسر الإبرة قبل التخلص منها.

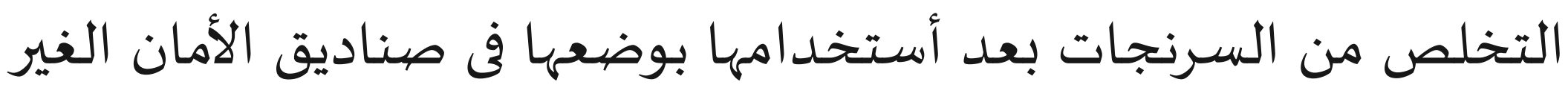

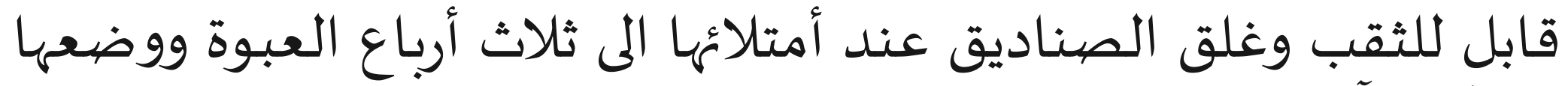
فى مكان آمن لحين التخلص النهائى منها. 


\section{العناصر الآساسية للحقن الآمن}

حماية البيئة والمجتمع بمنع الوصول الى مخلفات عملية الحقن:



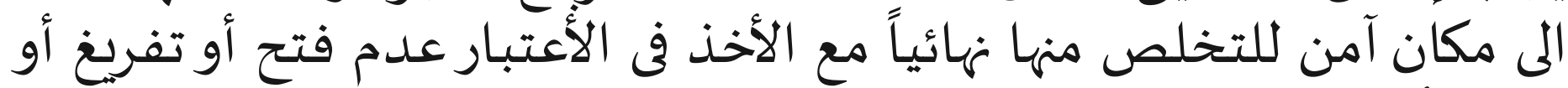
إعادة أستخدام العبوات بعد إحكام إغلاقها.

بعض الأساليب العملية الواجب أتباعها:

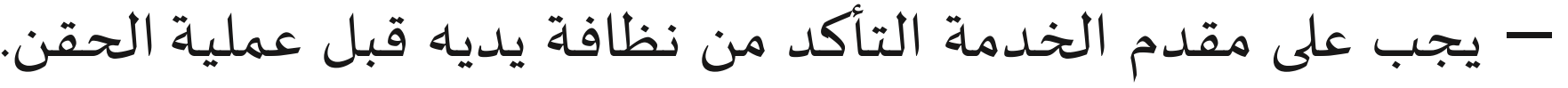

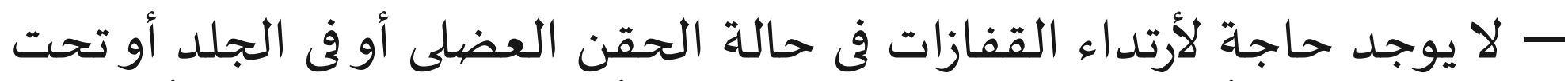

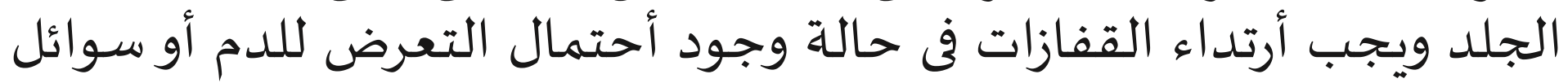

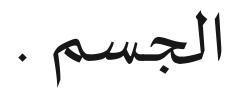

- يجب تنظيف الجلد موضع الحقن إذا كان متسخاً . - إتباع أسلوب عدم اللمس للمحافظة على السرنجة و إبرة الحقن معقمة. 


\section{إعادة معالجة الآلات (التنظيف - التطهير - التعقيم)}

تعد المعدات الطبية والآلات الجراحية من الأدوات الضرورياة للعناية

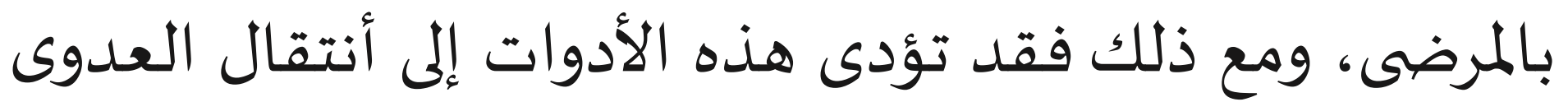

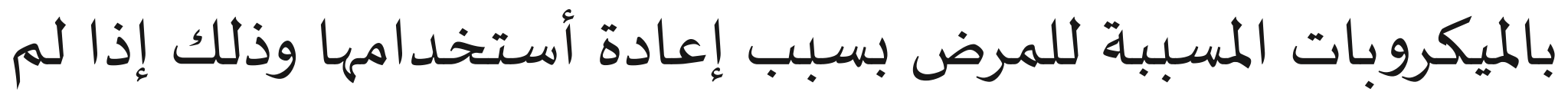



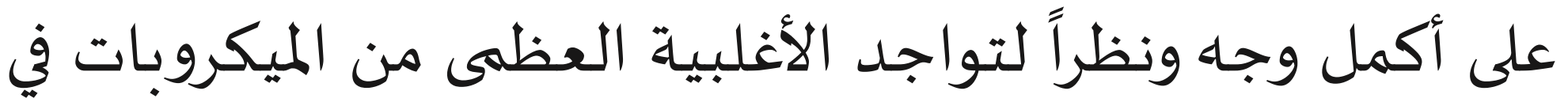
المواد العضيوية العالقة و الأقذار. 


\section{إعادة معالجة الآلات(عملية إزالة التلوث)}

عملية التنظيف تعتبر أول وأهم خطوات معالجة الآلات وقد تنتشر

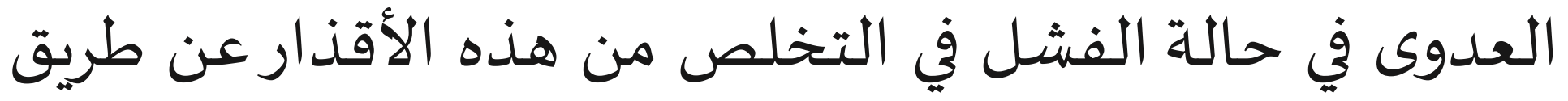
التنظيف، ومن ثم تؤثر عملية التنظيف على كفاءة ما يليها من

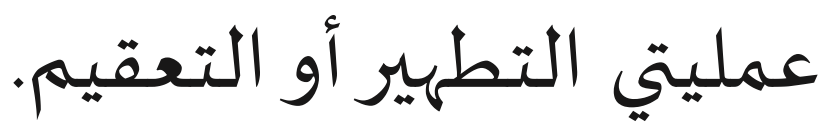

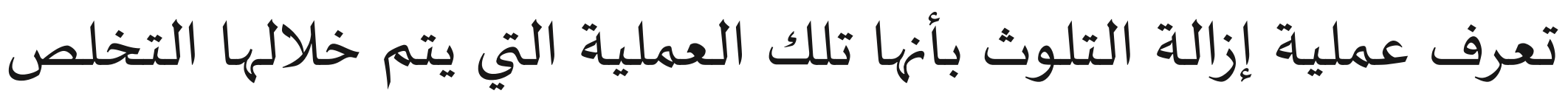



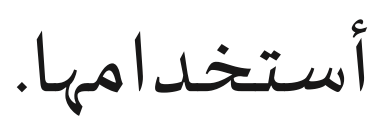




\section{عملية إزالة التلوث: أولاً التنظيف}

هى الخطوة الأولى لإزالة كافة المواد العالقة من المواد العضوية وغير



$$
\text { - الفرك لكى يسهل إزالة المادة العالقة }
$$

- ثم الشطف الجيد بالماء الجاري لإزالة تلك المواد

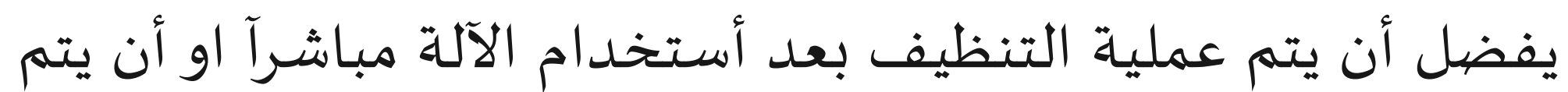

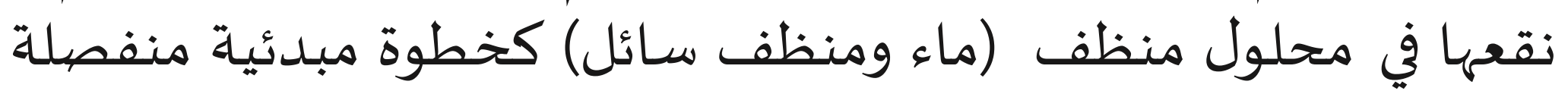
لحين البداء في عملية التنظيف




التعقيم 


\section{عملية إزالة التلوث: أولاً التنظيف (تابع)}

قد يفضل أن يتم نقع الأدوات والآلات قبل البدء في عملية التنظيف

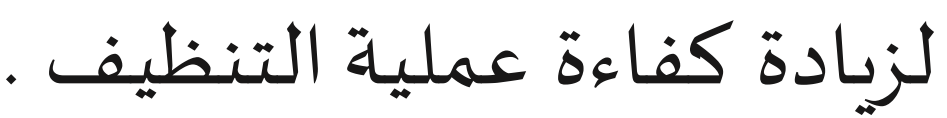

يتم ملء حاوية عميقة بكمية من الماء ومحلول منظف بحيث تحتوى

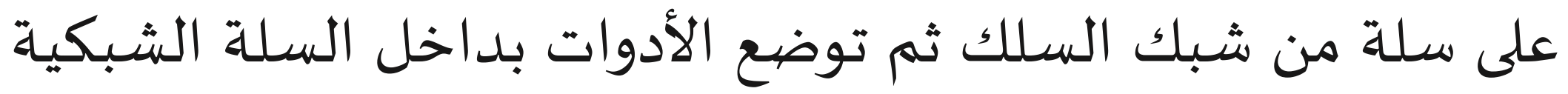

ثم يتم إرسال الحاوية بما تحوياه من آلات الى قسم التعقيم المركزى

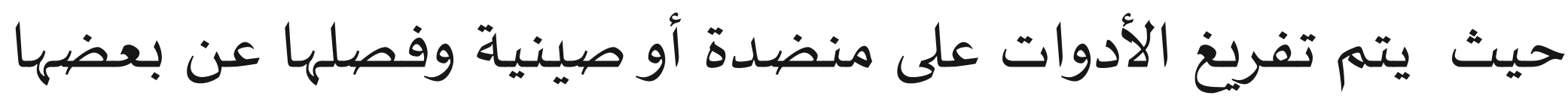
قبيل تنظيفها. 
لا يتم أستخدام قطع الصابون في عملية تنظيف الآلات لأهها تترك بقايا الصيابون على الأدوات. الحرص على أرتداء القفازات مطاطية شديدة التحمل 




هى القضاء على كافة الميكروبات ماعدا الميكروبات المتحوصلة يعتبر البديل الوحيد المقبول على الأقل لمعالجة الأدوات ذات

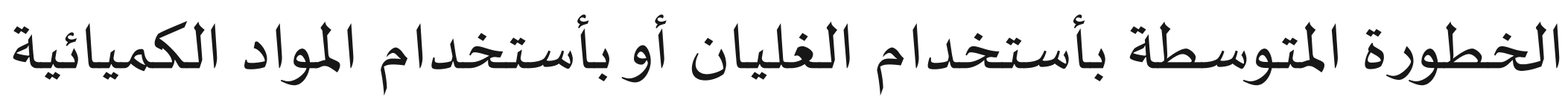
وذلك في حالة تعذر إجراء عملية التعقيم. 


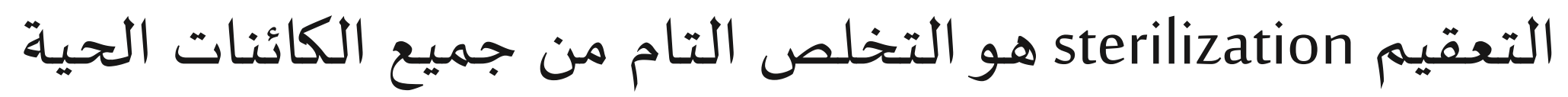

التي تسبب الأمراض بما فيها المتحوصيله (الفيروسات - البكتيريا -



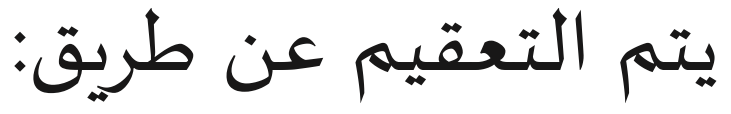

- أستخدام البخار تحت ضغط بأستخدام جهاز الأوتوكلاف. - التسخين الجاف باستخدام الفرن الحرارى. 


\section{الخطوات المتبعة في التعقيم (الأوتوكلاف)}

تنظيف الآلات بالماء الجاري والصابون السائل ثم تجفيفها جيدا. فك أو فتح الآلات المفصلية ووضعها مفتوحة. تغليف الآلات التي سيتم تخزينها بعد التعقيم وترقيمها وكتابة

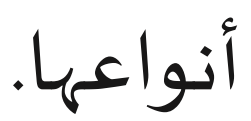

ترتيب الآلات في الأوتوكلاف بطريقة تسمح بمرور تيار البخار ووصوله الألهاء

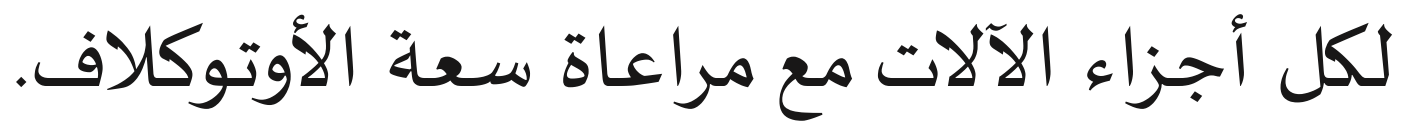

مراعاة تعليمات تشغيل الجهاز بدقة مما يسـاعد على الحفاظ على

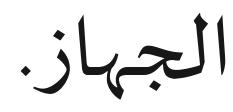




\section{الخطوات المتبعة في التعقيم (الأوتوكلاف)}

يبدأ حساب زمن التعقيم بحسب نوع الجهاز إذا كان يتم التعقيم بالبخار عن طريق الإزاحة فيكون كالآتى:

- عند درجاة 121 درجة مئوية لمدة 30 دقيقة للآلات المغلفة والمنسوجات - عند درجة 132 درجة مئوية لمدة 15 دقيقة للآلات المخلفة و25 دقيقة

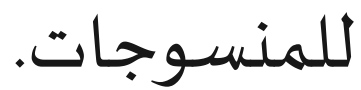

- يتم حساب زمن التعقيم للآلات الغير مغلفة عند 121 درجة مئوية لمدة 20 دقيقة أوعند درجة 132 درجة مئوية لمدة 4 دقائق . 


\section{الخطوات المتبعة في التعقيم (الأوتوكلاف)}

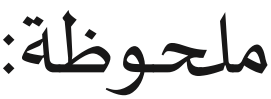

- لا يشمل زمن التعقيم الزمن الذي يتم أستغراقه للوصهول إلى درجاة

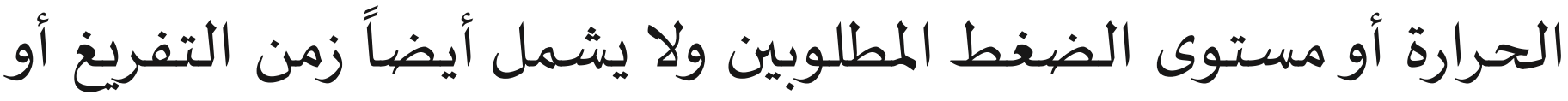
التجفيف

- يتم تخزين الآلات والأدوات المعقمة بمنطقة تخزين نظيفة جافة جيدة






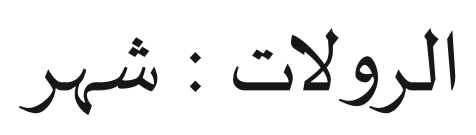

ورق الكريب : شهرفى حالة أستخدام طبقة مزدوجة من الورق

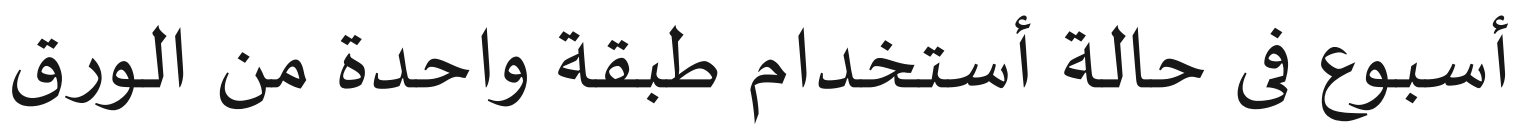

$$
\begin{aligned}
& \text { الفوط القماشية : ثلاثة أيام }
\end{aligned}
$$

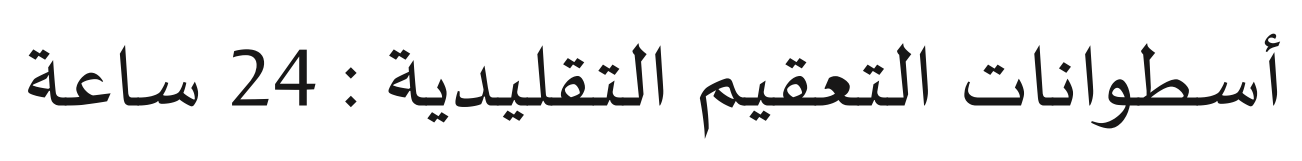

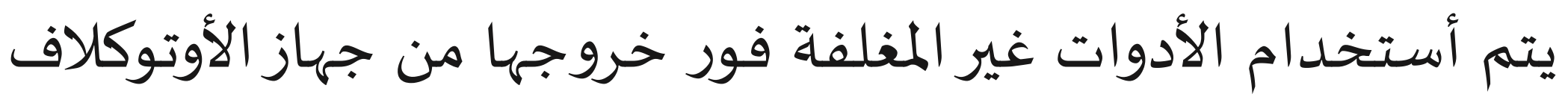


الغطاء لمدة 8 ساعات الفراري أو تئ 


\section{الخطوات المتبعة في الفرن الحرارى الجاف}

$$
\text { تجفم وضيع الآلات بفوطة نظيفة أو مناديل ورقية. }
$$

يتم ضبط مؤشر درجه الحراره على الدرجه المطلوبه ويتم تشغيل

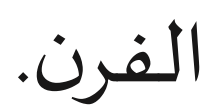

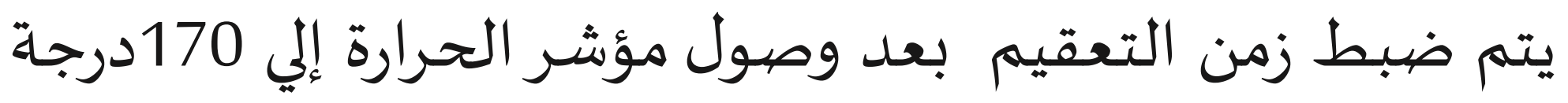





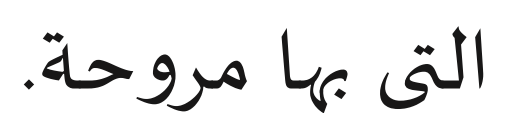




\section{الخطوات المتبعة في الفرن الحرارى الجاف (تابع)}

يتم ترك الآلات داخل الفرن لتبرد وتصل إلي درجة حرارة الغرفة قبل

$$
\text { إخراجها من الفرن. }
$$

يستخدم ملاقط (جفوت) معقمة لإخراج الآلات من الفرن لتستخدم

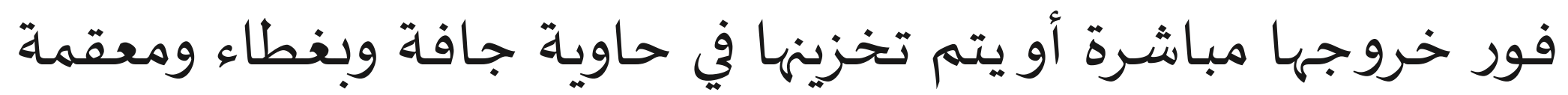
لمدة 8 سـاعات علي الأكثر. 
على الرغم من إمكانية تلوث الملاءات بالميكروبات إلا أن الإصابة



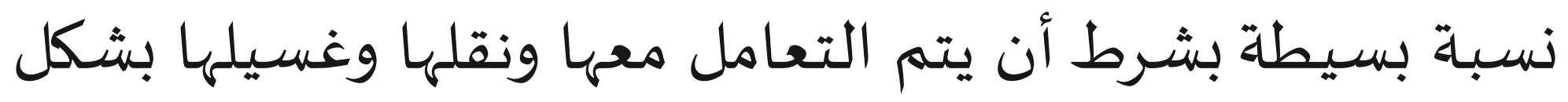

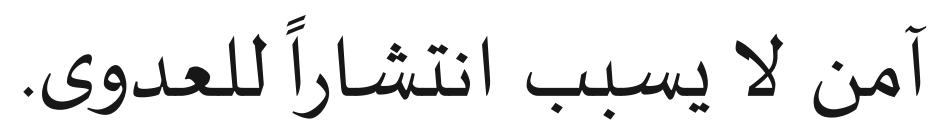

ينبغي تغيير الملاءات والأغطية يومياً أو كلما أتسخت . 


\section{تنظيف وتطهير البيئة}

تعتبر نظافة المنشاة الصحية أمرأ ضروريا من أجل صحة وسلامة المرضى والعاملين فيها ويعتبر التنظيف اليومي ضروري لإزالة الأتربة


رفع الروح المعنوية لدى المرضى والعاملين. 


\section{تنظيف وتطهير البيئة (تابع)}

يمتد تعريف مصطلح (نظافة البيئة) إلى التنظيف العام للأسطح

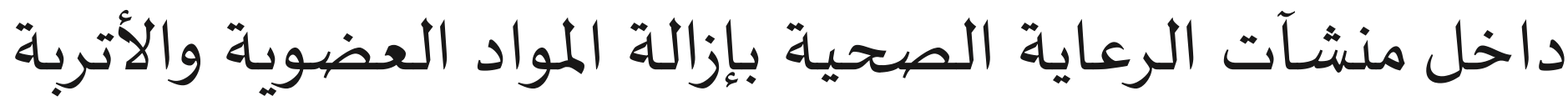

والقاذورات مما يؤدى إلى التخلص من نسبة كبيرة من الميكروبات.



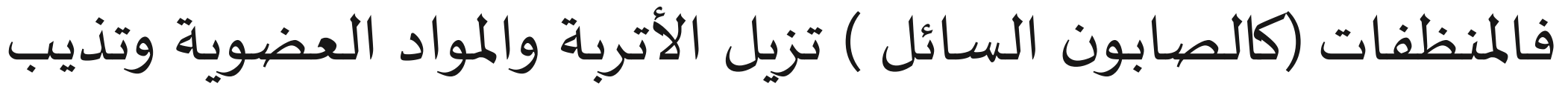



فى حالة تنظيف الأسطح يجب أرتداء القفازات شديدة التحمل . 


\section{تنظيف الدم وسوائل الجسم الاخرى}

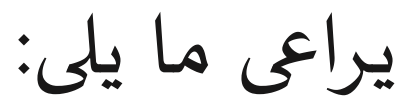

- أرتداء القفازات اللاتكس أحادية الأستخدام ويتم التخلص منها فور

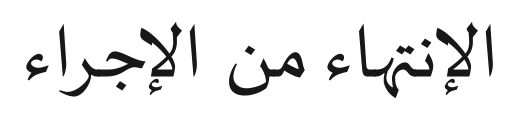

- إذا كانت كمية السائل أو الدم قليلة يمسح بقطعة من القطن أو القماش القياء

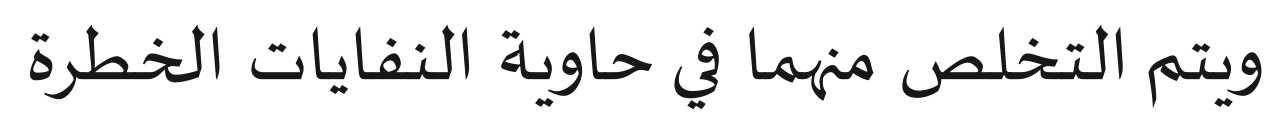

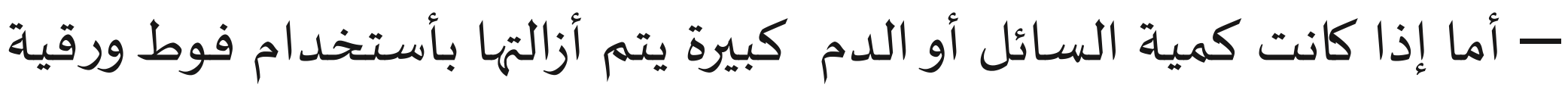

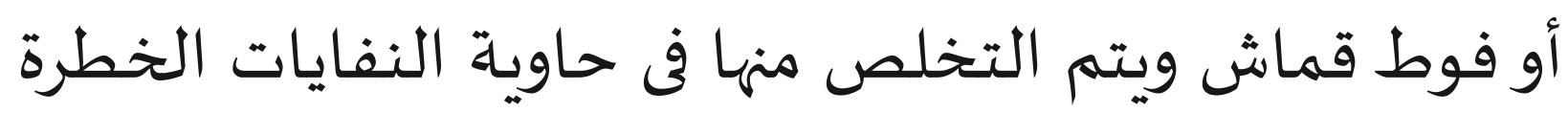




\section{تنظيف الدم وسوائل الجسم الاخرى (تابع)}

يلى ذلك تطهير المنطقة بالكلور بتركيز 5000 جزء في المليون ( 1 : 9 تخفيف بالماء من كلور 5 \% )



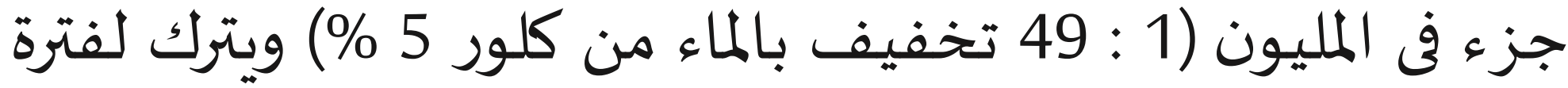
تلامس مناسبة ثم تجفف المنطقة .

ملحوظة : يراعى عند أستخدام محلول الكلور في التطهير الألتزام بزمن التلامس ( 10 دقائق ) 


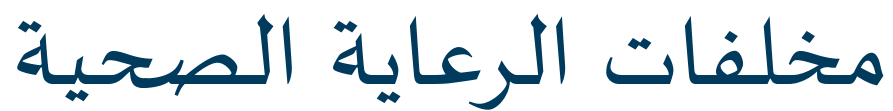

مخلفات غير خطرة: مثل أوراق تغليف المعدات الطبية والمستلزمات

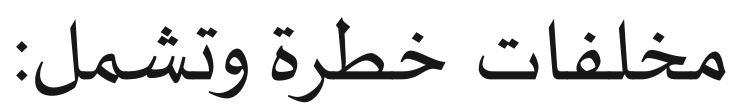

- المخلفات المعدية : وتشمل جميع الأشياء التى تلوثت أو يشتبة في تلوثها

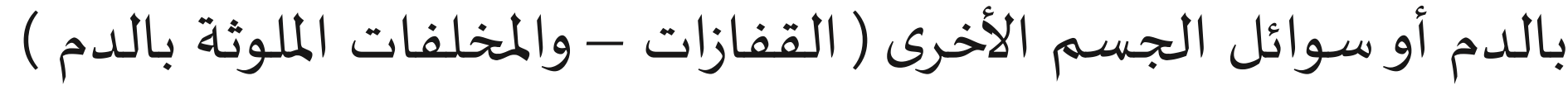

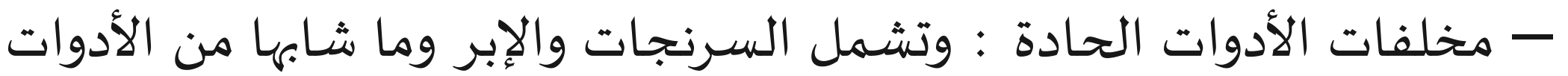

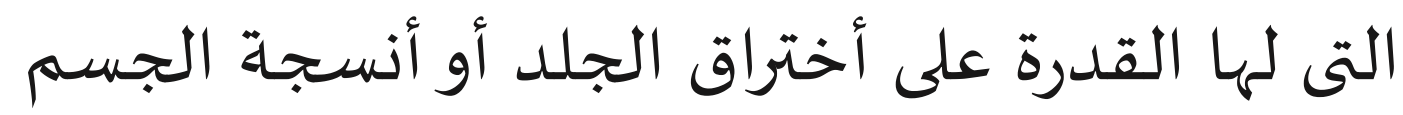




\section{خطوات التعامل مع النفايات الطبية}

الفصل: ويقصد باه الفصل عند المنبع وذلك بوضعها في أكياس

ملونة وحاويات مناسبة .

التداول: ويقصد باه جمع المخلفات ونقلها داخل المنشأة الصحية

التخزين المؤقت: ويقصد باه تخزين المخلفات في المنشأة لحين نقلها

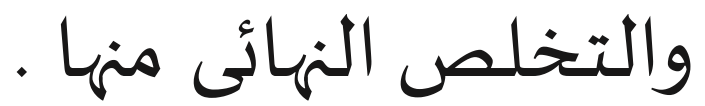

النقل خارج المنشأة: نقل المخلفات إلى مكان المعالجة والتخلص

النهائى خارج المنشأة 
المعالجة : معالجة النفايات الخطرة عن طريق الحرق أو الفرم أو

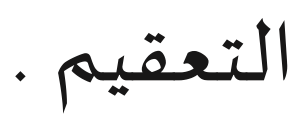

التخلص الهائى : وهو عملية التخلص من المخلفات بعد معالجته

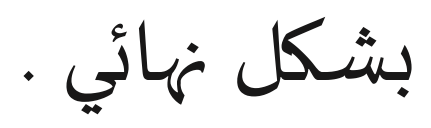

ملحوظة : يتعين جمع أكياس النفايات الخطرة ونقلها إلى منطقة

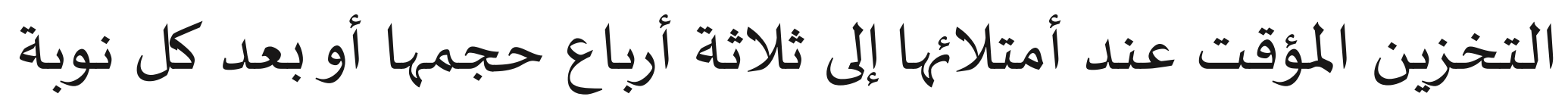

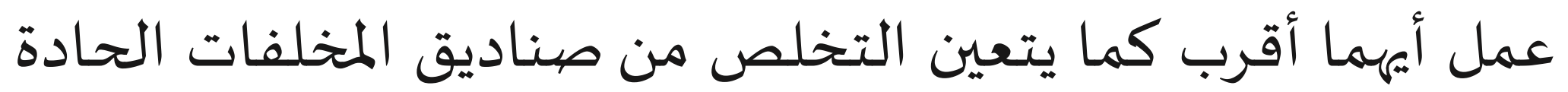

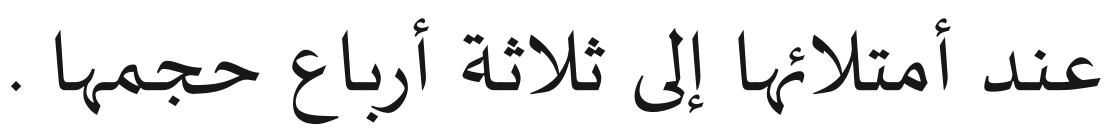


SESSION 5 


\section{Objectives}

- By the end of the session the participant will be able to:

- Discuss return of fertility after child birth and abortion.

- Discuss starting contraceptive methods after child birth and abortion.

- Explain surgical methods. 


\section{Postpartum Contraception}

- A woman is able to become pregnant as early as 4 to 6 weeks after childbirth.

- A woman should be using the family planning method as early as possible after childbirth, to avoid unplanned pregnancy and closely spaced pregnancies.

- Waiting at least 3 years before a woman becomes pregnant again is good for her health and her children health. 


\section{Postpartum Contraception (cont.)}

- Ideally family planning counseling should start during antenatal care.

- All women should receive FP counseling before discharge from hospital.

- A woman may choose to insert an IUD immediately post partum, provided she has received adequate counseling. 


\section{Postpartum Contraceptive Options}

\begin{tabular}{|c|c|c|}
\hline Family planning method & $\begin{array}{l}\text { Fully or nearly fully } \\
\text { breast feeding }\end{array}$ & $\begin{array}{l}\text { Partially or not breast } \\
\text { feeding }\end{array}$ \\
\hline $\begin{array}{l}\text { Lactation amenorrhea } \\
\text { method }\end{array}$ & could start immediately. & Not applicable. \\
\hline CuT-380A IUD & \multicolumn{2}{|c|}{$\begin{array}{l}\text { Within } 48 \text { hours after delivery, otherwise wait for } 4 \\
\text { weeks. }\end{array}$} \\
\hline Progestin only pills & \multirow[t]{2}{*}{$\begin{array}{l}\text { after child birth } \\
\text { (category2). }\end{array}$} & \multirow{3}{*}{$\begin{array}{l}\text { Immediately if not breast } \\
\text { feeding. } \\
6 \text { weeks after child birth if } \\
\text { partially breast feeding. }\end{array}$} \\
\hline Implants & & \\
\hline $\begin{array}{l}\text { Progestin only } \\
\text { ( } 3 \text { months) injectables }\end{array}$ & 6 weeks after child birth & \\
\hline
\end{tabular}




\section{Postpartum Contraceptive Options (cont.)}

\begin{tabular}{|c|c|c|}
\hline Family planning method & $\begin{array}{l}\text { Fully or nearly fully } \\
\text { breast feeding }\end{array}$ & $\begin{array}{l}\text { Partially or not breast } \\
\text { feeding }\end{array}$ \\
\hline $\begin{array}{l}\text { Combined contraceptives } \\
\text { ( COCs) }\end{array}$ & \multirow[t]{2}{*}{6 months after childbirth. } & \multirow{2}{*}{$\begin{array}{l}\text {-She can start COCs if she } \\
\text { has not other risk factor } \\
\text { for VTE if she has risk } \\
\text { factor for VTE delay to } 6 \\
\text { weeks. } \\
\text { - } 6 \text { weeks after childbirth } \\
\text { if partially breast feeding. }\end{array}$} \\
\hline $\begin{array}{l}\text { Monthly combined } \\
\text { injectable }\end{array}$ & & \\
\hline Male or female condoms & \multicolumn{2}{|l|}{ Can start immediately. } \\
\hline
\end{tabular}

Fertility awareness method
Can start when normal secretions have returned, or she has had 3 regular menstrual cycles. 


\section{Postabortion Contraception}

- Key messages :

- Fertility returns within 2 weeks after a first- trimester abortion, miscarriage and within 4 weeks after a second- trimester abortion, miscarriage.

- Women need protection from pregnancy almost immediately.

- If a woman wants to become pregnant again, encourage her to wait at least 6 months to reduce the risk of low birth weight, and repeated abortion.

- She should not have sex until bleeding stops to avoid infection. 


\section{Postabortion Contraception (cont.)}

- Key messages :

- Women with infection or genital injury must be treated before starting sexual activities.

- All modern methods can be started immediately following first trimester abortion or miscarriage.

- IUD can be inserted immediately after uncomplicated first-trimester abortion, firsttrimester miscarriage or after treating infection or injury.

- IUD insertion after second-trimester abortion requires specially trained physicians.

- All post abortion women should receive FP counseling before discharge from hospital. 


\section{Surgical Methods}

\section{Female Sterilization}

- What is female sterilization?

- It is a permanent method of contraception if there is medical indication.

- The procedure is used to block or cut the fallopian tubes and hence prevent fertilization of ovum.

- Also called tubal ligation or tubal sterilization. 


\section{Female Sterilization}

- Mechanism of action:

- Fallopian tubes are blocked or cut, eggs released from the ovaries cannot move down the tubes.

- Effectiveness:

- Less than 1 pregnancy per 100 women over the first year after having sterilization.

- Effectiveness varies slightly depending on how the tubes are blocked. 


\section{Surgical Methods}

Male Sterilization

- What is male sterilization?

- It is a simple surgical procedure, the provider cuts or blocks (vas deferens).

- Also called vasectomy. 


\section{Male sterilization}

- Mechanism of action:

- Works by closing off each of vas deferens keeping sperm out of semen, semen is ejaculated but it cannot cause pregnancy.

- Effectiveness:

- It carries small risk of failure, where men cannot have their semen examined 3 months after the procedure to see if it still contains sperm. Pregnancy rates are about 2 to 3 per 100 women over the first year after their husbands have had a vasectomy. 


\section{DAY THREE}


SESSION 1 


\section{Objectives}

- By the end of the session participants will be able to:

- Describe key facts about implanon (mode of action, effectiveness, side effects and when to use).

- Identify the woman who are not eligible for use of implanon (using WHO Medical Eligibility Criteria).

- Demonstrate Implanon insertion and removal on arm models according to the steps of the clinical skills checklist. 


\section{Implants}

- What are implants?

- Small plastic rods about the size of a matchstick, that release a progestin like the natural hormone progesterone.

- Contain (etonogestrel, $68 \mathrm{mg}$ ) third generation of progestagens).

- Prevent the release of ovum from the ovaries and thickens cervical mucus (thus blocks sperm from meeting an ovum).

- Implanon: 1 rod, effective for 3 years. 


\section{Effectiveness of Implants}

- One of the most effective and long- lasting methods.

- Less than 1 pregnancy per 100 women using implants over the first year.

- Return of fertility after implants are removed: no delay. 


\section{Advantages of Implants}

- Help protect against: risks of pregnancy, Symptomatic pelvic inflammatory disease.

- May protect against: iron-deficiency anemia, cancer endometrium and cancer ovary. 


\section{Disadvantages of Implants}

- Insertion and removal by a minor surgical procedure.

- Cannot be initiated or discontinued without service provider help.

- Needs to be inserted and removed by a specially trained service provider.

- High cost.

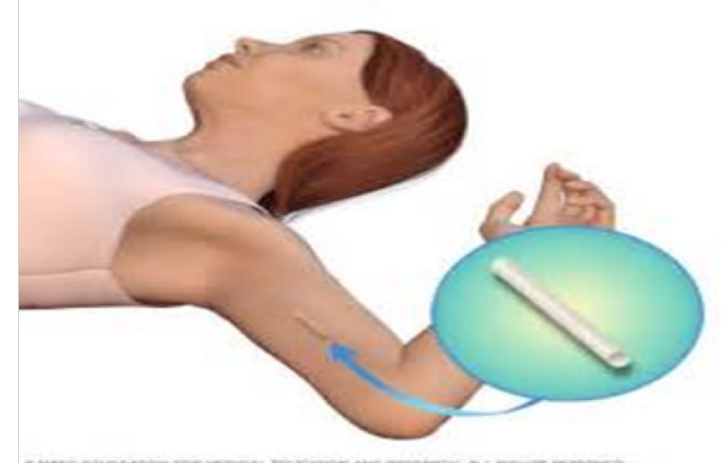




\section{Side Effects of Implants}

- Some users report the following:

- Noted changes in bleeding patterns: lighter bleeding, irregular bleeding or no monthly bleeding.

- Weight gain, headaches, dizziness, abdominal pain, mood changes, acne, breast tenderness and nausea.

- Physical changes: enlarged ovarian follicles. 


\section{Uncommon Complications of Implants}

- Infection at insertion site, most infections occur within the first 2 months after insertion.

- Difficult removal.

- Expulsion of implant, most often occur within the first 4 months after insertion. 


\section{Who Can Not Use Implants?}

- Category 3-4 of WHO Medical Eligibility

Criteria; women who:

- Have severe cirrhosis of the liver or liver tumor.

- Have blood clot in their legs or lungs.

- Have unusual vaginal bleeding.

- Have or have ever had breast cancer. 


\section{When to Start Implants?}

- Having menstrual cycles or switching from non hormonal method:

- If she is starting within 5 days after the start of her monthly bleeding, no need for a backup method.

- If it is more than 5 days after the start of her monthly bleeding, she can have implant any time it is reasonably certain she is not pregnant but she will need a backup method for the first 7 days after insertion.

- Switching from a hormonal method:

- she can start immediately if she has been using the method consistently and correctly. 


\section{When to Start Implants? (cont.)}

- Fully or nearly fully breastfeeding:

- If her monthly bleeding has not returned, and she is fully lactating she can have implant inserted any time after giving birth no need for a backup method.

- If her monthly bleeding has returned she can have implant inserted as advised for women having menstrual cycles. 


\section{When to Start Implants? (cont.)}

- If she wants to insert Implant 6 months after giving birth:

- If her monthly bleeding has not returned, and she is fully lactating she can have implant inserted any time if it is reasonably certain she is not pregnant but she will need a backup method for the first 7 days after insertion

- If her monthly bleeding has returned she can have implant inserted as advised for women having menstrual cycles. 


\section{When to Start Implants? (cont.)}

- Non breastfeeding women :

- If less than 4 weeks after giving birth: she can have implant inserted any time no need for a backup method.

- More than 4 weeks after giving birth: if her monthly bleeding has not returned, she can have implant inserted any time if it is reasonably certain she is not pregnant she will need a backup method for the first 7 days after insertion.

- If her monthly bleeding has returned she can have implant inserted as advised for menstruating women. 


\section{When to Start Implants? (cont.)}

- After miscarriage or abortion:

- She can insert immediately if she is starting within 7 days after first or second trimester miscarriage or abortion with no need for a backup method.

- If it is more than 7 days after first or second trimester miscarriage or abortion she can have implant inserted any time if it is reasonably certain she is not pregnant but she will need a backup method for the first 7 days after insertion. 
SESSION 2 


\section{Objectives}

- By the end of the session participants will be able to:

- Demonstrate Implanon insertion and removal on arm models according to the steps of the clinical skills checklist. 
SESSION 3 


\section{Objectives}

- By the end of the session the participant will be able to:

- Discuss pre- requisites for good counseling.

- Practice effective FP counseling skills including verbal and non verbal communication, tone of voice, feedback, use of questioning, reflecting feelings, listening , empathy......etc 
Successful Counseling in FP/RH Services Provision

- FP practice in Egypt respects the rights of women /families to decide on using FP methods freely and voluntarily through providing access to a wide range of modern contraceptives.

- It is the role of service provider (physician or nurse) to inform women and educate them about advantages and disadvantages of various FP methods to be able to make an informed choice.

- Counseling is an integral component of FP services. 
Successful Counseling in FP/RH Services Provision (cont.)

- Counseling is a process of face to face, two way communication between a health care provider and an individual/ couple.

- A counselor ( physician/nurse) provides factual information and assists the individual/ couple to make a decision about behavior change or using a FP method taking into account their feelings, concerns and living circumstances. 


\section{When to Provide FP Counseling?}

- The following are good moments to counsel women (and their husbands) about FP:

- Client seeking advice about birth spacing/ limiting.

- Antenatal care, especially during third trimester.

- Post natal care, especially first follow up visit after child birth.

- Child immunization or child care visits.

- Client seeking gynecological care or general health care (e.g. reproductive tract infections, diabetes, hypertension). 


\section{Successful Counseling in FP/RH Services Provision}

- Get to know the profile of clients that come for counseling:

- Socioeconomic background (e.g. education, employment, residence ....etc)

- Living conditions .

- Reproductive goals.

- Fears/Concerns.

- Expectations. 


\section{Counseling Skills}

- Verbal and non verbal communication.

- Tone of voice.

- Feedback.

- Effective use of questioning.

- Reflecting feelings.

- Listening.

- Relating and empathy.

- Paraphrasing and clarifying.

- Simplifying medical language.

- Effective use of AV materials.

- Combating misinformation and rumors. 


\section{Counseling Skills}

- Non verbal Counseling skills:

- Freshness

- Smile

- Open posture

- Less physical barriers

- Eye contact

- Appropriate distance

- Attentive and respectful attitude

- Leaning towards client 


\section{Positive Nonverbal Cues Include:}

- Leaning toward the client.

- Smiling, without showing tension.

- Facial expressions which show interest and concern.

- Maintaining eye contact with the client.

- Encouraging supportive gestures such as nodding one's head. 


\section{Negative Nonverbal Cues Include:}

- Not making or maintaining eye contact

- Glancing at one's watch obviously and more than once

- Frowning

- Fidgeting

- Sitting with the arms crossed

- Leaning away from the client 
SESSION 4 


\section{Objectives}

- By the end of the session the participant will be able to:

- Discuss the principles of GATHER.

- Practice effective FP counseling skills.

- Discuss role of men in FP. 


\section{Communicating with Clients}

\section{ROLES}

- Providers should remember ROLES when communicating with clients:

$-\mathrm{R}=$ Relax the client by using facial expressions showing concern.

$-0=$ Open up the client by using a warm and caring tone of voice.

$-\mathrm{L}=$ Lean towards the client, not away from.

$-E=$ Establish and maintain eye contact with the client.

$-\mathrm{S}=$ Smile. 


\section{Counseling}

\section{GATHER}

- The GATHER Approach:

$\mathrm{G}=$ Greet respectfully

$A=$ Ask/Assess needs

$\mathrm{T}=$ Tell information

$\mathrm{H}=$ Help choose

$E=$ Explain and demonstrate

$\mathrm{R}=$ Return and reinforce/refer 


\section{The GATHER Approach}

\section{Greet}

- Greet the client. She should feel welcome. Build a rapport with the client by greeting her and making her feel comfortable.

\section{AsK}

- Ask questions effectively in a friendly manner using words that the client understands. Listen patiently without being judgmental. Identify her needs by asking relevant questions about personal, social, family, medical and reproductive health including reproductive tract infections, sexuallytransmitted diseases, family planning goals and past/ current use of family planning methods. 


\section{The GATHER Approach (cont.)}

\section{Tell}

- Tell the client relevant information to help her reach a decision and make an informed choice regarding contraception methods.

\section{Help}

- Help the client reach a decision and give other related information. 


\section{The GATHER Approach (cont.)}

\section{Explain}

- Explain about the methods in detail including, its efficacy, how to use, side effects and medical eligibility criteria, as well as common problems and its management.

\section{Return}

- Return for ongoing contraceptive method is advised 


\section{Components of FP Counseling}

- Good counseling helps clients choose and use family planning methods that suit them. Clients differ, their situations differ, and they need different kinds of help. The best counseling is tailored to the individual client. 


\section{Components of FP Counseling}

Client type

New clients with a method in mind.

\section{Usual counseling tasks}

- Find out why client wants this method and if she knows about other methods.

- Support the client's choice, if she is medically eligible.

- Discuss how to use the method and how to cope with any side effects.

- If preferred method is not suitable for her, explain reasons and provide other options. 


\section{Components of FP Counseling (Cont.)}

Client type

New client with no method in mind.

\section{Usual counseling tasks}

- Ask the client about the method that's she knows. Explain all the methods

- Help the client consider methods that might suit her.

- If the client shows interest in a specific method, provide more information about the method (mode of action, effectiveness, cost and side effects)

- If client is unable to make a choice, suggest to her a method that suits her needs and living conditions.

- Support the client's choice, give instructions on use, and discuss how to cope with any side effects. 


\section{Components of FP Counseling (Cont.)}

Client type

Usual counseling tasks

Returning clients with no problems.
- Ask a friendly question about how the client is doing with the method and if she has any questions or concerns.

- Inform her about routine follow up.

- Check to see if she is still eligible before this method. 


\section{Components of FP Counseling (Cont.)}

Client type

Returning clients with problems.

\section{Usual counseling tasks}

- Understand the problem and help resolve it whether the problem is side effects, trouble using the method, an uncooperative husband.

Complications:

- If complications requires discontinuing method, offer advice on other FP options and treat complications. 
المعلومات التالية تمثل أهمية كبيرة أثناء جلسة المشورة

معلومات المنتفعة عن تنظيم الأسرة

• التجارب السابقة للمنتفعة عن تنظيم الأسرة

الخطة المستقبلية بشأن الإنجاب

موقف الزوج أو العائلة من تنظيم الأسرة 


\section{المعلومات التالية تمثل أهمية كبيرة أثناء جلسـة المشورة (تابع)}

$$
\begin{aligned}
& \text { المنتفعات اللاتى لديهن أحتياجات خاصة: } \\
& \text { - المنتفعات صغار السن. } \\
& \text { - - المنتفعات بعد الولادة. }
\end{aligned}
$$

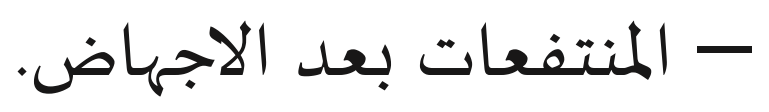

$$
\begin{aligned}
& \text { - المنتفعات كبار السن. }
\end{aligned}
$$

- السيدات المتعايشـات مع فيروس نقص المناعة البشرى. - السيدات اللاتى يعترض أزواجهن على تنظيم الأسرة.

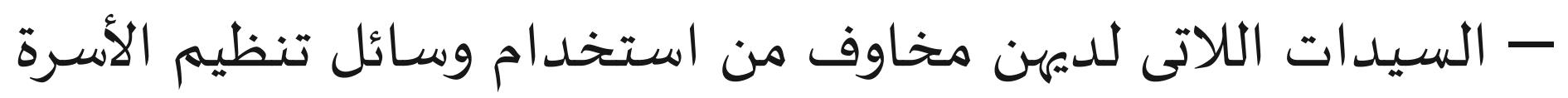

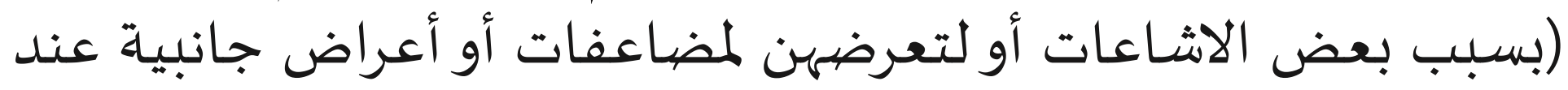

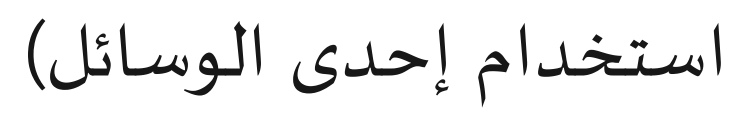




\section{المعلومات التالية تمثل أهمية كبيرة أثناء جلسـة المشورة (تابع)}

\section{التأكيد على أخذ الوسيلة في الموعد المحدد.}

مراجعة المنتفعة للطبيبة عند حدوث مضاعفات أو أعراض جانبية



أعطاء معلومات كافية عن مكان الإحالة عند الضرورة مع المتابعة. حبوب منع الحمل أحادية الهرمون يجب أخذها يوميا دون توقف و



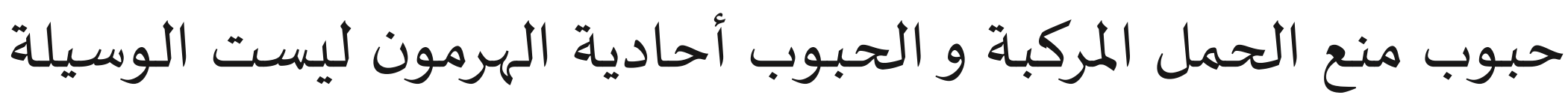
المثلى للمنتفعات اللاتى لديهن صعوبة في أحسب أخذها دون نسيان. 


\section{المعلومات التالية تمثل أهمية كبيرة أثناء جلسة المشورة (تابح)}

\section{لمستخدمات كبسولات الأمبلانون: - العودة في موعد إزالة الكبسولة.}

- التاكيد على ان الأثار الجانبية شائعة ولكنها نادرا ما تكون ضارة. - الرجوع للطبيب إذا سببت لك ضيقا. - الرجوع للطبيب فى أى وقت إذا كان لديك مشكلة أو تريدين أزالة

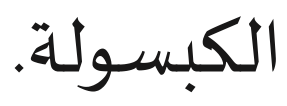




\section{Men Engagement in FP}

- Why does engaging men matter?

- ICPD ( Cairo 1994),recommended that programs and polices to enable men to play a more active role in reproductive decisions, including FP method choice and use.

- The husband plays a key role in family size decision making, it is essential that he be adequately informed on $\mathrm{FP} / \mathrm{RH}$.

- A well informed husband will encourage and support his wife to use FP methods.

- Male acceptance is associated with high continuation rates and use-effectiveness rates.

- Male permission on seeking health care and financial support. 


\section{How Can Men Play a More Active Role in FP?}

- Be informed about various FP products which will help in changing their attitudes that are not supportive to women right to access FP/RH.

- Support their wife's decision to use contraception.

- Accompany their wives to the clinic to receive FP methods and counseling. 


\section{How Can Men Play a More Active Role in FP? (cont.)}

- Show understanding of the method sideeffects on their wives and support their wives to tolerate theses side-effects.

- Use male methods (e.g. Condom)as an effective method, if their wives can't use methods. 
SESSION 5 


\section{Objectives}

- Demonstrate Skills in FP counseling through 4 role plays. 
DAY FOUR 
DAY FOUR: FIELD VISIT 


\section{Objective}

- Participants will observe and practice counseling and insertion of IUDs and Implanon on real clients at the FP clinics. 


\section{DAY FIVE}


SESSION 1 


\section{Objectives}

- By the end of the session the participant will be able to:

- Discuss components of premarital care program.

- Discuss infertility counselling for newly married couples.

- Discuss the definition and consequences of GBV.

- Identify the role of men in ending GBV.

- Discuss health complications and legal consequences of FGM/C.

- Explain causes, types, symptoms and prevention of sexually transmitted infections (STIS/HIV). 


\section{Premarital Care Program}

\section{Objectives}

- Help couples enjoy satisfying, stable and healthy life.

- Provide couples with medical, social and psychological support.

- Discuss with the couples their thoughts and fears freely.

- Promote awareness regarding reproductive health, FP and healthy life style.

- Emphasize the preventive aspects of reproductive health (Rh factor incompatibility- hazards of German measles- STIs including AIDS). 


\section{Premarital Care Program}

Objectives (cont.)

- Discuss the impact of medical disorders upon health including: DM, hypertension, TB, mumps in men, operations, menstrual history, immunization

- Provide counseling regarding high risk behavior, including those related to HIV, hepatitis B, and other infectious diseases.

- Assist in overcoming the impact of hereditary disorders by identifying problems followed by counseling.

- Help reduce the incidence of common haemoglobinopathies eg: thalassemias and sickle cell disease. 


\section{Premarital Care Program}

Counseling

- Explain the basic RH/FP issues to the couple including:

- Anatomical facts

- Reproductive physiology

- Suitable FP methods

- Healthy timing and spacing of pregnancy 


\section{Premarital Care Program}

History Taking

- Ask the couple about:

- Hereditary diseases

- Diseases: diabetes, tuberculosis, hypertension, STIs, mumps in men... etc

- Operations: laparotomy, varicocele, hydrocele, hernia.

- Menstrual history: menarche, regularity, duration, flow, dysmenorrhea and date of last menstruation

- Immunization for rubella and tetanus of the future wife 


\section{Premarital Care Program}

\section{Examination}

- General examination

- Abdominal examination:

- Distribution of pubic hair

- Abdominal masses

- Scars 


\section{Premarital Care Program}

Investigations

- Premarital investigation:

- Rh factor - blood group

$-\mathrm{CBC}$

- Urine analysis

- Other investigations (only if needed), such as:

- VDRL for syphilis

- ELISA for hepatitis or HIV

- Ultrasound and hormone assays for female

- Semen analysis 


\section{Newly Married Couples Fertility Concerns}

- Newly married couples usually ask about their potential fertility.

- Among couples with no fertility problems; $85 \%$ of women will become pregnant in the first year.

- On the average, pregnancy occurs after 3-6 months of unprotected sex. 


\section{Infertility}

- Infertility is the inability to produce children.

- Infertility occurs in both men and women.

- On the average, it affects 1 in every 10 couples.

- A couple is considered infertile after having 12 months of unprotected sex without pregnancy.

- A couple can be infertile whether or not the woman has been pregnant in the past. 


\section{Preventing Infertility}

- Counsel clients about STIs.

- Proper treatment of infection.

- Following proper infection prevention practices when performing medical procedures.

- Contraception does not cause infertility: With most contraceptive methods, there is no delay in return of fertility after stopping them. 


\section{Infertility Counseling}

- Counsel both partners together.

- A man is just as likely to have infertility as a woman.

- Wait for 12 months of continuous marital life before starting investigations.

- Counsel couples about having sex in the fertile period ( days 8 through 19 of every cycle).

- Refer both partners for evaluation. 


\section{Gender-Based Violence}

- Gender based violence (GBV) is an overall term for any harm that is perpetrated against a person's will and that result from power inequity that is based on gender roles. GBV is a human right violation, a public health challenge, and affects social, political and economic participation. 


\section{Gender-Based Violence (cont.)}

- GBV is a public health challenge that takes many forms, from domestic and sexual to harmful practices such as early marriage and FGM/C.

- Violence against women and girls is one of the most systemic and wide spread violations of human rights worldwide.

- The impact of violence ranges from immediate to long term multiple physical, sexual, and mental consequences, it negatively affects women's general well being and prevents women from fully participating in society. 


\section{Role of Men in Ending GBV}

- Men are active participants and promoters of changing the culture of violence that exist.

- They should take responsibility for how much they contribute to or oppose to violence: actions, words, silence.

- Educate themselves and listen to people who have different experience with violence.

- Attend events that relate to anti violence work. 


\section{Role of Men in Ending GBV (cont.)}

- Share their knowledge about GBV with other men and young men in family, work, community...etc

- Take actions against violence when they see it.

- Reach out for the large number of men in male -dominated institutions, industries and associations for sensitizing them regarding their role in promoting gender equality and women empowerment. 


\section{Female Genital Mutilation/Cutting (FGM/C)}

- FGM comprises all procedures that involve partial or total removal of the external female genitalia or other injury to the female genital organs for non-medical reason.

- There is no medical indication for FGM, it is not part of OB/GYN education and training and there are no health benefits of FGM/C.

- FGM is a violation of human rights of girls and women and constitute an extreme form of discrimination against girls and women.

- This practice also violates a persons right to health , security and physical integrity and the right to life when the procedure results into death. 


\section{Female Genital Mutilation (cont.)}

- FGM practice in Egypt:

- FGM prevalence is $92 \%$ in women in reproductive age (15 - 49 years).

- It is $61 \%$ among girls (15 - 17 years).

- The average age at which FGM is practiced is 10.5 years.

- Medicalization of FGM:

- Dramatic shift in FGM practice from TBA to medical practitionals ( physicians and nurses), $31 \%$ of women (15- 49 years ) were cut by physicians compared to $82 \%$ of girls (o - 19 years) - (EDHS 2014). 


\section{External Female Genitals}

- The external genital organs include the mons pubis, labia majora, labia minora, Bartholin glands, and clitoris. The area containing these organs is called the vulva. The external genital organs have these main functions:

- Enabling sperm to enter the body.

- Protecting the internal genital organs from infectious organisms.

- Providing the sexual pleasure.

- Directs the urine in a stream by the labia minora preventing splashing and soiling of the vulva. 


\section{Role of the Clitoris and Labia}

- These organs are very rich of nerve endings that make them extremely sensitive organs. Touch stimulation of the nerve endings in the labia and especially the clitoris produces sensations of sexual pleasure and orgasm. 


\section{Sexual Desire}

- Sex starts with desire in response to various stimuli like vision, sound, smell, memory, etc...

- Desire is a purely mental process that originates in the brain (not in external genital organs) and is influenced by personal, cultural, ethical and social factors.

- Desire may or may not progress to the next phases of the sexual response cycle i.e. arousal, plateau, orgasm then resolution phases. 


\section{Sexual Response Cycle}

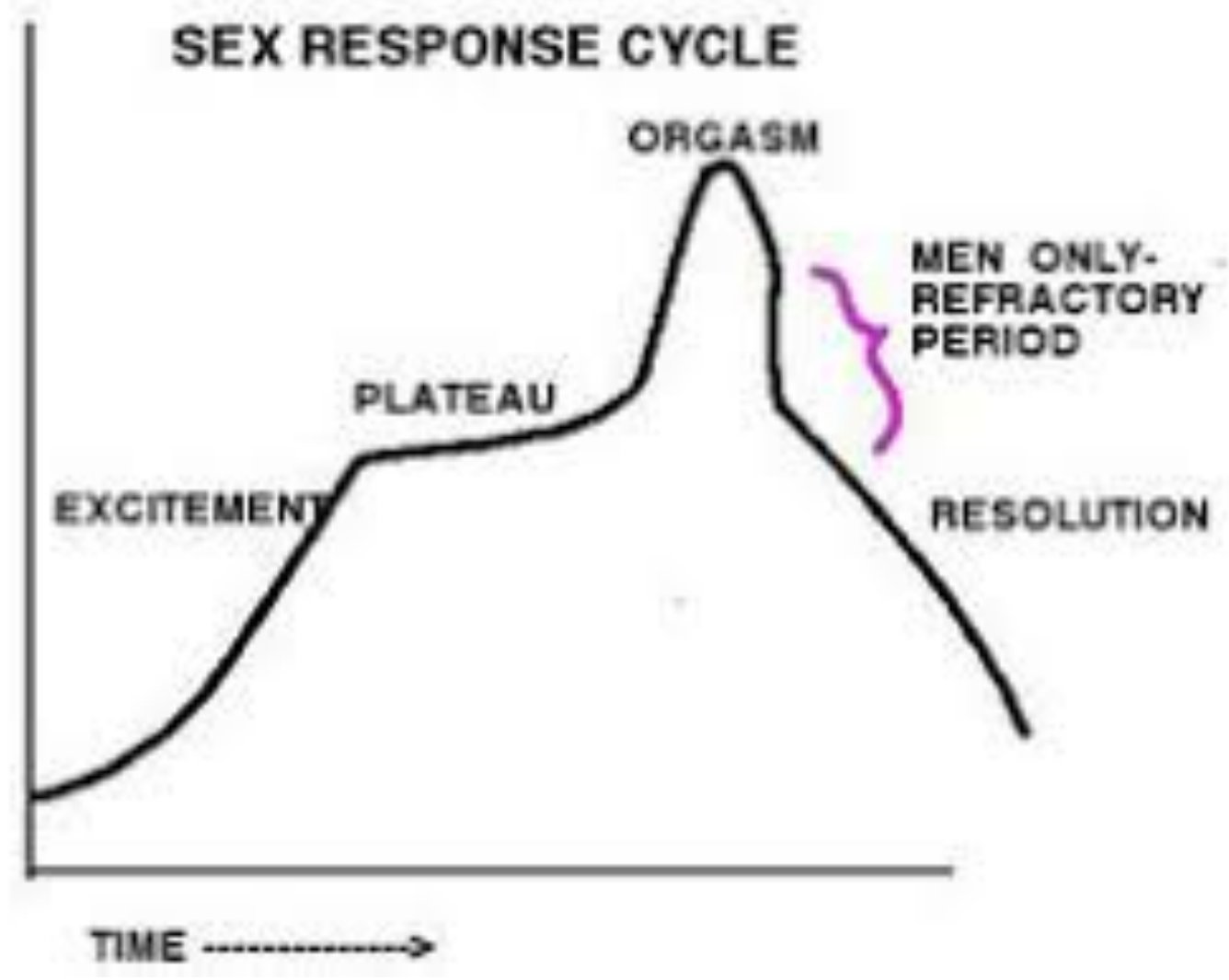




\section{Classification of FGM/C}

- Female genital cutting is classified into 4 major types:

- Type I: Often referred to as clitoridectomy, this is the partial or total removal of the clitoris and/or the prepuce.

- Type II: Often referred to as excision, this is the Partial or total removal of the clitoris and the labia minora, with or without excision of the labia majora. 


\section{Classification of FGM/C (cont.)}

- Type III: Often referred to as infibulations, this is the narrowing of the vaginal opening through the creation of a covering seal. The seal is formed by cutting and repositioning the labia minora, or labia majora, sometimes through stitching, with or without removal of the clitoris.

- Type IV: This includes all other harmful procedures to the female genitalia for non-medical purposes, e.g. pricking, piercing, incising, scraping and cauterizing the genital area. 


\section{Types of FGM/C}

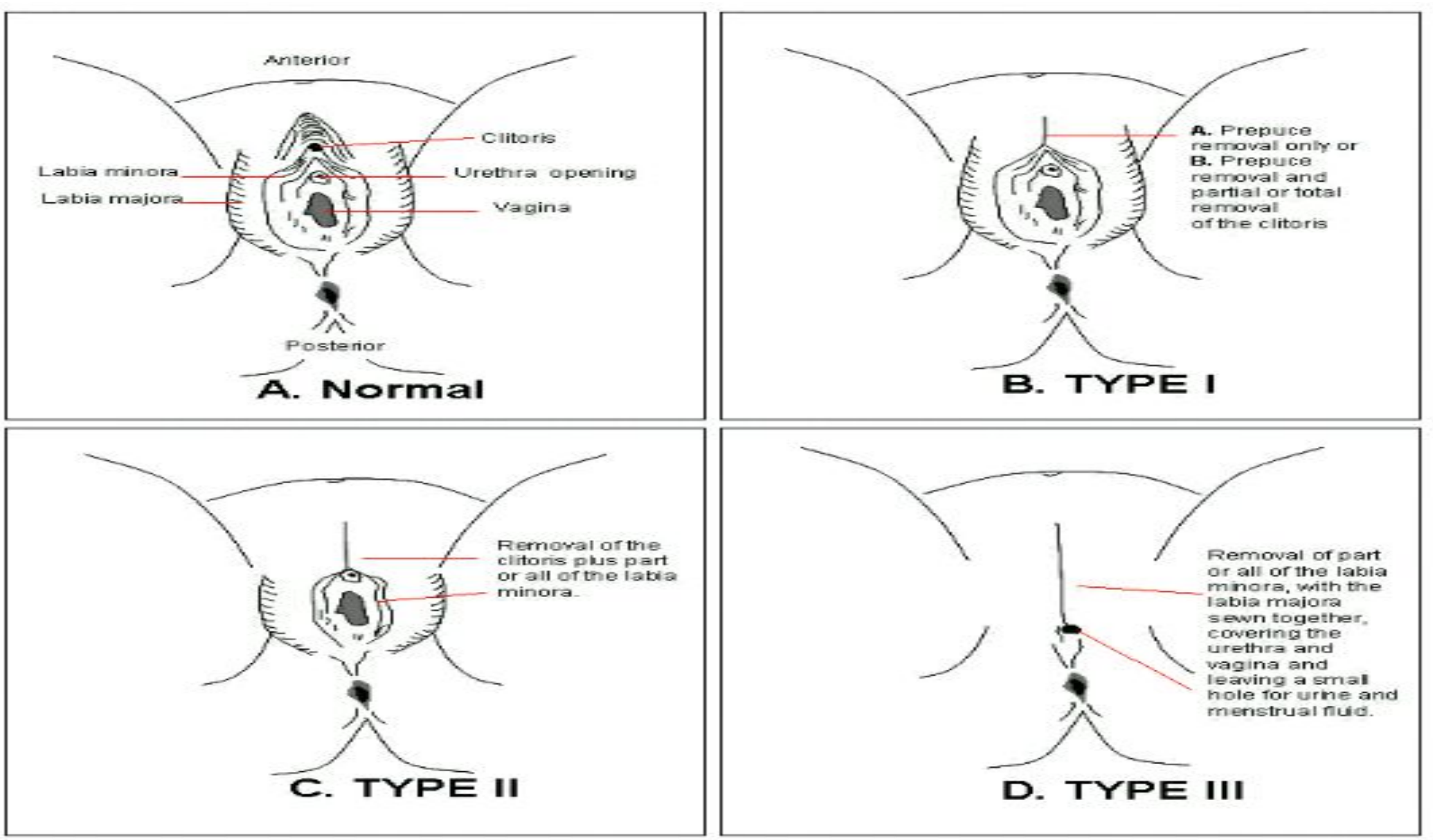




\section{Immediate Complications of FGM/C}

- Severe pain.

- Urinary problems.

- Excessive bleeding.

- Wound healing problems.

- Genital swelling.

- Injury to surrounding genital tissues.

- Fever.

- Shock.

- Infections.

- Death. 


\section{Long Term Complications of FGM/C}

- Painful urination ( chronic UTI).

- Vaginal problems ( infections ..).

- Painful menstrual periods.

- Scar tissue /Keloid.

- Sexual problems( Painful intercourse, fear from sex vaginismus).

- Risk of difficult childbirth.

- Need for corrective surgery.

- Psychological problems (depression, anxiety, post-traumatic stress disorders, low selfesteem). 


\section{عقوبة ختان الإناث}

ينص التشريع الجديد بالسجن المشدد من 5-7 سنوات على من يقوم بإجراء هذه العملية، بدلا من العقوبة السابقة و التى كانت

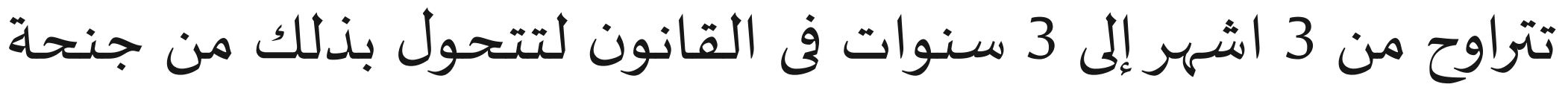
إلى جناية. و السجن المشدد 15 سنة إذا أفضى الأمر إلى عاهة

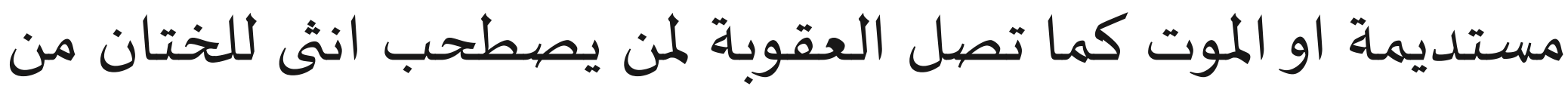

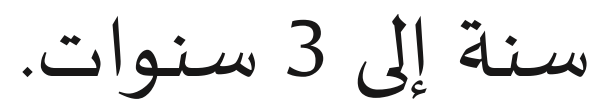




\section{Sexually Transmitted Infections(STIs)/HIV}

- STIs spread through sexual contact.

- Several types of organisms cause STIs; those caused by bacteria generally can be cured, STIs caused by viruses generally cannot be cured, although they can be treated to relieve symptoms

- Infections can be found on the skin of the genitals and areas around them, and some also in the mouth, throat and rectum.

- Some STIs cause no symptoms, other may cause discomfort or pain. 
Chancroid Bacterial

Vaginal , anal, and oral sex.

None

Yes

Vaginal and anal sex

Chlamydia Bacterial rarely from genitals to mouth.

From mother to child during pregnancy.

Yes

Vaginal and anal sex or contact between

From mother to child during delivery.

Yes mouth and genitals .

In blood from mother

Hepatitis B Viral

Vaginal and anal sex or to child during from penis to mouth. delivery or in breast

No milk.

Genital or oral contact with an ulcer, including from mother to child vaginal and anal sex, during pregnancy or No also genital contact in delivery area without ulcer 
Vaginal and anal sex, very rarely, oral sex. from mother to child during pregnancy or delivery or in breast milk.

from mother to child during No genital contact or contact between mouth and genitals. delivery.

from mother to child during pregnancy or delivery

from mother to

Vaginal ,anal and oral sex. child during delivery.
Genital or oral contact with an ulcer, including vaginal and anal sex.

Syphilis 


\section{Complications of Sexually Transmitted Infections}

- If not treated, STIs may cause:

- Pelvic inflammatory disease.

- Infertility.

- Chronic pelvic pain.

- Cervical cancer.

- Some STIs can also greatly increase the chance of becoming infected with HIV.

- HIV suppresses the immune system and eventually lead to death. 


\section{Sexually Transmitted Infections}

Key Points for Providers and Clients

- People with STIs including HIV can use most family planning methods safely and effectively.

- Male and female condoms can prevent STIs when used consistently and correctly.

- STIs can be reduced in other ways; having a mutually faithful relationship with an uninfected partner. 


\section{Sexually Transmitted Infections}

Key Points for Providers and Clients (Cont)

- Some STIs have no signs or symptoms in women, if a woman thinks her partner may have an STI, she should seek care.

- Some STIs can be treated; the sooner treated, the less likely to cause long-term problems, such as infertility or chronic pain.

- In most cases, vaginal discharge are due to infections that are not sexually transmitted e.g. Bacterial vaginosis and Candidiasis. 


\section{Risk of Sexually Transmitted Infections?}

- The risk of acquiring an STI, including HIV, depends on a person's behavior, the behavior of that person's sexual partner or partners, and how common those diseases are in the community.

- Understanding their own risk for HIV and other STIs helps people decide how to protect themselves and others. 


\section{Early Detection of STls}

- Signs and symptoms:

- Unusual discharge

- Sores

- Pain

- Diagnosis:

- Inspection

- During vaginal and abdominal examination

- Management:

- Treat accordingly

- Refer 


\section{Common Signs and Symptoms that May Suggest an STI}

\section{\begin{tabular}{l|l} 
Symptoms & Possible cause
\end{tabular}}

Discharge from the penis- pus, clear or yellow-green drip.

Abnormal vaginal bleeding or bleeding after sex.

Burning or pain during urination.

Lower abdominal pain or pain during sex.

Swollen and/ or painful testicles.

Itching or tingling in the genital area.
Commonly: chlamydia, gonorrhea. Sometimes: trichomoniasis.

chlamydia, gonorrhea, pelvic inflammatory disease.

chlamydia, gonorrhea, herpes.

chlamydia, gonorrhea, pelvic inflammatory disease.

chlamydia, gonorrhea

Commonly: trichomoniasis.

Sometimes: herpes. 


\section{Common Signs and Symptoms that may Suggest an STI (Cont)}

\section{Symptoms}

Blisters or sores on the genitals, anus, surrounding areas, or mouth.

Warts on the genitals, anus, or surrounding areas.

Unusual vaginal discharge- changes from normal vaginal discharge in color, consistency, amount, and/ or odor.

\section{Possible cause}

Herpes, syphilis, chancroid.

Human papillomavirus.

Most commonly: bacterial vaginosis, candidiasis ( not STIs, see common vaginal infection often confused with sexually transmitted infections, below)

Commonly: trichomoniasis. Sometimes: chlamydia, gonorrhea. 
Common Vaginal Infections Often Confused with Sexually Transmitted Infections

- The most common vaginal infections are not sexually transmitted, e.g. bacterial vaginosis and candidiasis.

- Washing the external genital area with unscented soap (with no chemicals) and clean water are good hygiene practice and it helps some women avoid vaginal infections.

- Using douches, detergents, disinfectants, or vaginal cleaning or drying agents are not recommended hygienic practices. 


\section{HIV/AIDS}

- People can live with HIV for many years without any signs or symptoms of infection. Eventually, they develop AIDS the condition when the body's immune system breaks down and is unable to fight certain infections, known as opportunistic infections.

- There is no cure for HIV infection or AIDS, but antiretroviral (ARV) therapy can slow the disease progresses, improve the health of those with AIDS and prolong life. ARVs also can reduce mother to child transmission. 
SESSION 2: PROJECT ORIENTATION 
SESSION 3: SOCIAL MEDIA 
SESSION 4: CLOSING SESSION 


\section{THANK YOU}

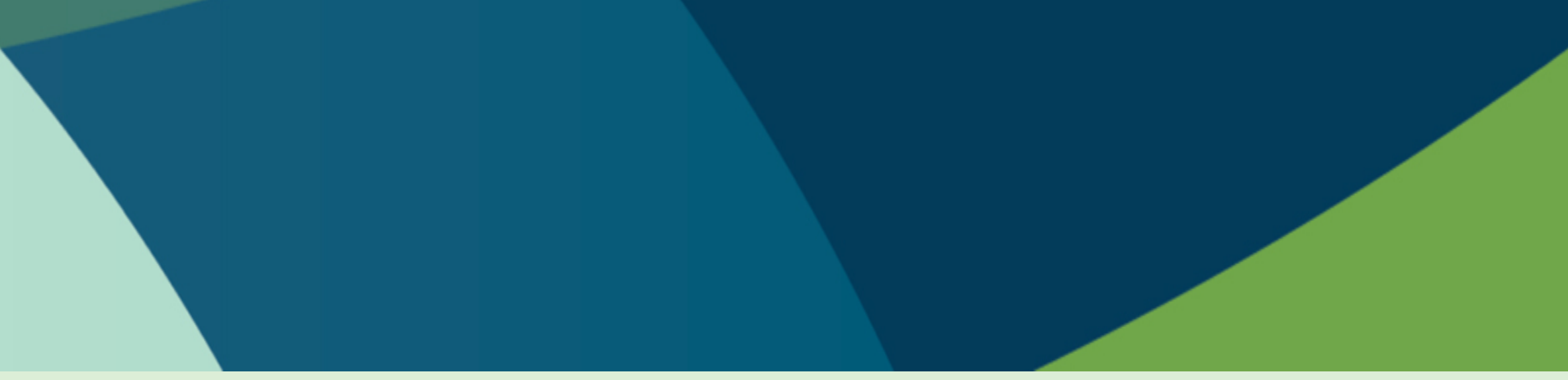

The Evidence Project is made possible by the generous support of the American people through the United States Agency for International Development (USAID) under the terms of cooperative agreement no. AIDOAA-A-13-00087. The contents of this presentation are the sole responsibility of the Evidence Project and Population Council and do not necessarily reflect the views of USAID or the United States Government.

The Evidence Project seeks to expand access to high quality family planning/reproductive health services worldwide through implementation science, including the strategic generation, translation, and use of new and existing evidence. The project is led by the Population Council in partnership with the Population Reference Bureau. 
(c) 2018 The Evidence Project. All rights reserved.

Use of these materials is permitted only for noncommercial purposes.

The following full source citation must be included:

2018. "Private Sector Physicians Curriculum," PowerPoint slides. Cairo, Egypt: The Evidence Project

This presentation may contain materials owned by others. User is responsible for obtaining permissions for use from third parties as needed. 